\title{
Distribution of Gold
}

in Igneous Rocks

By DAVID GOTTFRIED, JACK J. ROWE, and ROBERT I. TILLING

GEOLOGICAL SURVEY PROFESSIONAL PAPER 727

An investigation of the abundance and

distribution of gold in plutonic and volcanic

rocks of diverse magma types and tectonic settings

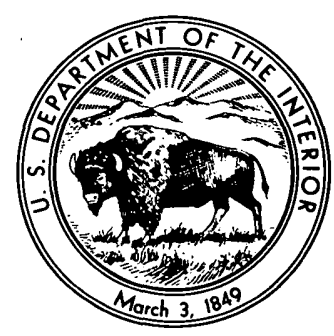

UNITED STATES GOVERNMENT PRINTING OFFICE, WASHINGTON : 1972 
UNITED STATES DEPARTMENT OF THE INTERIOR

ROGERS C. B. MORTON, Secretary

GEOLOGICAL SURVEY

W. A. Radlinski, Acting Director

Library of Congress catalog-card No. 70-184860

For sale by the Superintendent of Documents, U.S. Government Printing Office Washington, D.C. 20402 - Price 50 cents (paper cover)

Stock Number 2401-2023 


\section{CONTENTS}

Abstract

Introduction

Acknowledgments

Analytical procedure

Precision

Accuracy

Contamination effects

Gold content in plutonic rocks

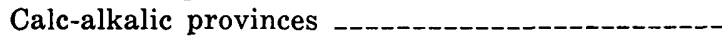

Alkalic provinces

Gold content in basaltic associations

Oceanic provinces

Hawaiian Islands

Continental provinces

Plateau basalts and associated rocks, Oregon and Washington

Basalts of the Snake River Group and associated rhyolitic rocks, Idaho

Greenstone Flow, Michigan

Hypabyssal (diabase) provinces

Triassic basin, Eastern United Stat

Precambrian diabase, southeastern Missouri

Great Lake intrusion, Tasmania -..--_-----

Gold content in basalt-andesite-rhyolite associations_-

Calc-alkalic provinces

Cascade Range and adjacent areas, Oregon and California
Page

1

2

2

3

5

5

6

6

8

8

8

9

10

10

11

11

12

12

13

14

15

15

15
Gold content in basalt-andesite-rhyolite associationsContinued

Calc-alkalic provinces-Continued

Jemez Mountains, N. Mex

Yellowstone National Park, Wyo,, and vicinity_

Precambrian metavolcanic rocks, central Arizona

Beatty area, Nevada

Challis Volcanics, central Idaho

Southern Appalachians, Virginia and North Carolina

Alkalic provinces

Big Bend National Park, Tex 19

Boxelder and Shonkin Sag laccoliths, Montana_ $\quad 20$

Summary discussion of gold in volcanic associations_- $\quad 20$

Mode of occurrence of gold in igneous rocks _-_-_-_ $\quad 22$

Abundance level in minerals _- 22

Distribution of gold between minerals in a rock_- $\quad 23$

Bearing of primary gold abundance on gold mineralization

Boulder batholith region, Montana

Dillsburg and Cornwall districts, Pennsylvania

Jerome district, central Arizona _-

Bullfrog district, Nye County, Nev

The Mother Lode, California

Thermal springs, Yellowstone National Park,

Wyo

References
Page

15

17

17

17

17

7

(1)

2

3

\section{ILLUSTRATIONS}

FIGURE 1. Schematic representation of tests of reproducibility of gold determinations of three rhyolites and one quartz monzonite

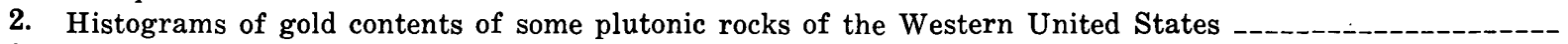

3. Composite histograms of gold content of calc-alkalic and alkalic plutonic rocks; provenance not considered.

4. Histograms of gold content of rocks in some basaltic associations from oceanic provinces

5. Histograms of gold content of rocks from some continental basaltic provinces of the United States

6. Histograms of gold content of rocks from some hypabyssal (diabase) provinces of the United States and Tasmania

7. Graphs showing variation in gold and copper abundance with mafic index and depth of samples from the Great Lake sheet; Tasmania

8. Histograms of gold content of rocks from some calc-alkalic and basalt-andesite-rhyolite associations

9. Histograms of gold content of rocks from some provinces

10. Graph showing variation of gold abundance with copper abundance of samples from four basaltic suites_-

11. Graph showing variation of gold content with copper content in altered samples of Butte Quartz Monzonite from underground workings, Butte district, Montana

12. Graph showing positive correlation of secondary sericite with gold abundance for samples from two intrusions in Uzbekistan, U.S.S.R.

13. Triangular diagram showing normative plagioclase, orthoclase, quartz, and variation in gold content of Precambrian rhyolites and quartz porphyry of the Yavapai Series, central Arizona 


\section{TABLES}

TABLES 1. Replicate determinations of gold in selected igneous rocks

2. Reproducibility of gold determinations on splits and composites of selected igneous rocks

3. Selected literature pertinent to the plutonic samples analyzed

4. Summary of distribution of gold in various plutonic provinces

5. Distribution of gold in calc-alkalic and alkalic plutonic rocks generalized according to rock type regardless of province

6. Summary of gold content in basaltic associations

7. Summary of gold content in basalt-andesite-rhyolite associations -

8. Average gold content in selected rocks representative of different volcanic associations

9-13. Distribution of gold in-

9. Minerals of some rocks from the Southern California batholith

10. Minerals of some rocks from the Boulder batholith, Montana

11. Minerals of some rocks from the Sierra Nevada batholith and Coast Range plutons, California

12. Minerals of a sample of the Silver Plume Granite, Silver Plume, Colo

13. Different density fractions of some samples of Butte Quartz Monzonite from underground workings

14. Distribution of gold and copper in a drill core in Butte Quartz Monzonite, Butte district, Silver Bow County, Mont.

15. Distribution of gold and copper in some samples of Butte Quartz Monzonite from underground workings in the Butte district, Montana

16. Comparison of gold concentration in samples of host rocks from the Mother Lode district with samples from the Sierra Nevada batholith

17. Ranges of gold content in rhyolite, thermal waters, and precipitates from thermal waters, Yellowstone National Park, Wyo

18-26. Distribution of gold in-

18. Rocks of the Southern California batholith

19. Rocks of the Sierra Nevada, Coast Range, and Transverse Ranges, Calif

20. Rocks of the Idaho batholith

21. Rocks of the Boulder batholith, Montana

22. Rocks of the Tatoosh pluton, Mount Rainier National Park, Wash

23. Four plutonic rocks from the Rocky Mountains, Colo

24. Plutonic rocks of the White Mountain Plutonic Series, New Hampshire

25. Some alkalic plutonic rocks from North Carolina and South Carolina

26. Volcanic rocks from Hawaii

27. Distribution of gold and copper in volcanic rocks from the Mid-Atlantic Ridge and East Pacific Rise

28. Distribution of gold in plateau basalts and other volcanic rocks, Oregon and Washington

29. Distribution of gold in basalts of the Snake River Group and associated rhyolitic rocks, Idaho_--_-----

30. Distribution of gold and copper in the Greenstone Flow of the Michigan copper district

31. Distribution of gold in basalt and diabase from the Triassic basin, Eastern United States -...--..--

32. Distribution of gold in Precambrian diabase intrusions, Iron County, Mo

33. Distribution of gold and copper in the Great Lake intrusion, Tasmania

34-44. Distribution of gold in-

34. Volcanic rocks of the Western Cascades, Oreg

35. Volcanic rocks of the Southern High Cascades, Calif., and vicinity

36. Some rhyolites from Mono County, Calif

37. Volcanic rocks of the Jemez Mountains, N. Mex

38. Volcanic rocks from Yellowstone National Park, Wyo., and vicinity _-_._-_._-

39. Metamorphosed Precambrian silicic volcanic rocks in central Arizona

40. Volcanic rocks from the Beatty area, Nevada

41. Some samples of the Challis Volcanics, central Idaho

42. Some calc-alkalic metavolcanic rocks from the southern Appalachians, North Carolina and Virginia

43. Alkalic igneous rocks from Big Bend National Park, Tex

44. Subsilicic alkalic rocks from central Montana 


\title{
DISTRIBUTION OF GOLD IN IGNEOUS ROCKS
}

\author{
By David GotTFried, JACK J. Rowe, and RoberT I. TIlling
}

\section{ABSTRACT}

New data on gold content are presented for about 700 igneous rocks from various petrographic provinces, which represent different magma types from widely different geographic areas and tectonic settings. The gold content was determined by neutron-activation analysis combined with fire assay for radiochemical separation of gold. The method yields results reproducible to \pm 10 percent in the range above $1 \mathrm{ppb}$ (part per billion) gold; below $1 \mathrm{ppb}$ the reproducibility drops to \pm 30 percent.

In the Mesozoic-lower Tertiary calc-alkalic batholiths from the Western United States (the Southern California, Sierra Nevada, Idaho, and Boulder batholiths), the highest gold content (as much as $10 \mathrm{ppb}$ ) occurs in some of the gabbroic and tonalitic rocks of the Southern California batholith. The felsic members of each of the batholiths generally contain from 0.5 to $1.5 \mathrm{ppb}$ gold. Plutonic rocks, ranging from gabbro to granite in alkalic provinces of the Eastern United States (White Mountain Plutonic Series in New Hampshire and Piedmont physiographic province in the southern Appalachians) are characterized by low gold content. Limited data on the gold content in some major and accessory minerals indicate that relatively higher gold concentration is associated with pyrite, magnetite, and mafic silicates than with the felsic minerals. The apparent affinity of gold for early crystallizing minerals is consistent with the overall trend of progressive depletion of gold from mafic to silicic rocks.

The suites of basaltic rocks studied include tholeiitic, low$\mathrm{K}_{2} \mathrm{O}$-high- $\mathrm{Al}_{2} \mathrm{O}_{3}$, and alkalic basalts from continental as well as oceanic environments. Alkalic basalts appear to have distinctly lower gold content $(\sim 0.6 \mathrm{ppb})$ than most Hawaiian and continental basalts of the tholeiitic magma type (2-3.5 $\mathrm{ppb}$ ). Low- $\mathrm{K}_{2} \mathrm{O}$ basalts from the oceanic ridges of the Atlantic and Pacific Oceans have lower gold content $(\sim 0.6 \mathrm{ppb})$ than chemically similar basalts from North Carolina and northern California. In the Triassic province of the Eastern United States, samples from the diabase-granophyre suite from Dillsburg, Pa., contain three to four times more gold than undifferentiated basalts from elsewhere in the province and may be the result of remobilization or later introduction.

A chalcophilic tendency for gold has been observed in a diabase-granophyre suite from Tasmania where the variation pattern of gold is closely parallel to that shown by copper. A gross correlation between gold and copper has also been noted in a few petrochemically distinct basaltic provinces. Basalts of alkalic affinities are characterized by significantly lower copper and gold content than most tholeiitic basalts; the relatively high concentration of gold in the Dillsburg suite is accompanied by a.high copper content. In unaltered diabase-granophyre suites, the variation trends for gold indicate that gold either reaches a maximum in the intermediate stage or remains uniform in abundance during magmatic differentiation. In the calcalkalic volcanic suites of rocks, gold content decreases on the average as rock composition grades from basalt and andesite to dacite and rhyolite. Basalts from the orogenic belt of the Western United States tend to have higher gold content than those of more stable regions of the continental interior or the primitive basalts of the Hawaiian Islands. Unaltered rhyolitic rocks of both the calc-alkalic and alkalic suites are generally uniform and low in gold content $(0.1-$ $1.0 \mathrm{ppb})$ despite differences in geologic age, provenance, or petrochemical features. The subsilicic-alkalic series of comagmatic rocks (shonkinite-syenite association) from two laccoliths in central Montana have a higher gold content than other types of alkalic volcanic or plutonic provinces.

The available data provide little support for the view that gold is concentrated in the residual liquids during magmatic differentiation in any of the calc-alkalic or alkalic provinces. The variation trends indicate that gold either remains relatively constant or decreases during differentiation processes.

The gold content in suites of unaltered igneous rocks spatially associated with gold mineralization from selected areas-Boulder batholith region, Montana; Cornwall, Pa.; Jerome district, Arizona; Bullfrog district, Nevada; Mother Lode, California-is virtually the same as petrographically equivalent rocks from provinces devoid of mineralization. The relatively high concentration of gold that exceeds background levels for a given region invariably occurs only locally in altered rocks and may be ascribed to remobilization_or secondary introduction. Geochemical abundance data alone neither provide unique criteria in identifying broad segments of the crust favorable for gold mineralization nor specify processes that resulted in the economic concentration of gold. Thus, in any exploration program, geologic factors, such as petrologic, structural, and tectonic setting, must be considered in conjunction with purely geochemical abundance factors.

\section{INTRODUCTION}

Because of analytical difficulties involved in the measurement of gold in parts per billion, quantitative data on the distribution of gold in igneous rocks from the United States (and elsewhere) are extremely limited. In connection with the U.S. Geo- 
logical Survey's study of heavy metals, we have investigated the occurrence and distribution of gold in igneous rocks and minerals representative of diverse magma types and tectonic associations. The sampled suites include: plutonic calc-alkalic rocks from the Mesozoic-lower Tertiary batholiths of the Western United States (the Southern California, Sierra Nevada, Idaho, and Boulder batholiths) ; calcalkalic volcanic rocks from Oregon, northern California, and New Mexico; alkalic basalt-trachyandesiteriebeckite rhyolite volcanic rocks from Texas; and tholeiitic, low- $\mathrm{K}_{2} \mathrm{O}$, and alkalic basalts from continental as well as oceanic environments. In addition to general chemical and mineralogic studies, nearly all these suites have been, or are currently being, analyzed for their content of lithophilic trace elements, such as thorium, uranium, niobium, and tantalum. For many of the samples, complete chemical analyses of the rock and selected minerals are also available. In all, some 700 samples were analyzed for gold by neutron-activation procedures, and the resultant data presented herein probably constitute the largest body of such data accumulated to date by any single laboratory.

The objectives of this reconnaissance study are manifold :

1. To understand better the geochemical behavior of gold in magmatic processes,

2. To establish so-called background levels of gold in unaltered igneous rocks, that is, levels presumably reflecting primary abundances undisturbed by secondary concentration or remobilization, for the possible definition and appraisal of broad regions or rock units as potential sources of low-grade ores,

3. To relate, if possible, geochemical gold provinces to major metallogenic provinces,

4. To recognize, if possible, the association of gold with other elements in various geochemical environments,

5. To test sampling and analytical procedures, inasmuch as in this study we are concerned with gold abundance in parts per billion, and

6. To outline areas for more detailed topical studies that will bear quantitatively on the geochemical behavior of gold during magmatism.

Obviously, it is beyond the scope of this report to treat extensively samples from any given locality or to explore fully the ramifications of generalizations suggested by the data; rather, our purpose is to construct the overall framework into which such in-depth specialized studies must fit.
A comprehensive bibliography of the geology and geochemistry of gold has been compiled by Cooper (1971).

\section{ACKNOWLEDGMENTS}

We are greatly indebted to Robert L. Smith and Paul C. Bateman for guidance and encouragement in the work presented here. We thank our numerous colleagues in the Geological Survey and others acknowledged in the report for contributing samples and pertinent geologic information. Margaret Cooper and Michael Fleischer kindly called to our attention and provided some of the Russian literature on the geochemistry of gold. We are grateful to Michael Fleischer and L. P. Greenland for their review of an early version of this report and suggestions for its improvement.

\section{ANALYTICAL PROCEDURE}

Neutron-activation analysis is particularly well suited to the study of the generally low concentration level of gold in igneous rocks because the method is highly sensitive and eliminates possible reagent contamination. A rapid, sensitive method of neutron-activation analysis was developed by Rowe and Simon (1968) for studying distribution of gold in geologic materials, and it is particularly useful in studies (such as this one) involving hundreds of samples. This method uses fire assay for the radiochemical separation of gold after irradiation and is summarized below.

Sixteen 1-gram samples and four standards are irradiated together for 10 hours in a flux of $5 \times 10^{12}$ neutrons per square centimeter per second. Samples are allowed to cool for $\mathbf{1 0}$ days to permit the decay of most of the activity, primarily that of $\mathrm{Na}^{24}$, which has a 15-hour half-life. They are then processed through fire assay; with gold carrier added, and the final gold bead is weighed to determine the yield. The beads are then counted in a $\mathrm{NaI}$ ( $\mathrm{Tl}$ ) well-type crystal coupled to a multichannel analyzer. The $0.413 \mathrm{Mev}$ peak for $\mathrm{Au}^{198}$ is used in calculating the amount of gold present. Counting is repeated after two days to verify the decay of 2.7-day $\mathrm{Au}^{198}$. The method of Covell (1959) is used for calculating the area under the peak. If a value of about 400 counts per minute per nanogram of gold is found 10 days after irradiation, then there is a suitable sensitivity for the levels of gold concentration commonly found in igneous rocks.

Two sets of 16 samples plus four monitors can be irradiated at one time by using two tubes of the reactor for 10 hours. After the cooling period, 40 
samples can be processed through fire assay in 1 day. The counting is performed overnight by using automatic sample changers and two crystals simultaneously. Thus, under normal circumstances; it is possible to analyze as many as 80 samples per week.

\section{PRECISION}

To estimate the precision of the analytical procedure, several igneous rocks which differ in composition (basalt to granite), texture (glassy to coarsegrained), and concentration levels (a few tenths of a part per billion to $4 \mathrm{ppb}$ gold) were chosen for detailed study (tables 1 and 2). Replicate determinations of gold from a given bottle (material ground to pass 100-mesh sieve) indicate that precision, expressed as relative deviation, of analyses of the basaltic specimens is about 10 percent (table 1 , samples TLW-67-17, HW-6, and HK 1955) ; in general replicate analyses of coarser grained rocks having comparable concentration levels yield somewhat lower precision, around 15 percent (table 1, samples G-1, W-1, and G-78).

TABLE 1.-Replicate determinations of gold, in parts per billion, in selected igneous rocks

[Data in the first five sample columns are neutron-activation analyses from Rowe and Simon (1968, table 2); data in the last column are from this report]

\begin{tabular}{|c|c|c|c|c|c|c|}
\hline & $\begin{array}{c}\text { TLW-67-17 } \\
\text { Cone Crater, } \\
\text { Hawaii, } \\
\text { basalt }\end{array}$ & $\begin{array}{c}\text { HW-6 } \\
\text { Kilauea, } \\
\text { Hawaii, } \\
\text { basaltic } \\
\text { glass }\end{array}$ & $\begin{array}{c}\text { HK } 1955 \\
\text { Kilauea, } \\
\text { Hawaii, } \\
\text { basalt }\end{array}$ & $\underset{\text { Granite }}{\text { G-11 }}$ & $\begin{array}{c}\text { W-122 } \\
\text { Diabase }\end{array}$ & $\begin{array}{c}\text { G-78 } \\
\text { Silver Plume } \\
\text { Granite, Front } \\
\text { Range, Colo., } \\
\text { quartz } \\
\text { monzonite }\end{array}$ \\
\hline & $\begin{array}{l}4.3 \\
4.5 \\
4.1 \\
5.0 \\
4.2 \\
4.4 \\
4.2 \\
4.2\end{array}$ & $\begin{array}{l}1.6 \\
1.7 \\
1.7 \\
1.6 \\
1.6 \\
1.2 \\
1.4 \\
1.5\end{array}$ & $\begin{array}{r}1.0 \\
.8 \\
1.0 \\
.9 \\
1.0 \\
.9 \\
.8 \\
1.0\end{array}$ & $\begin{array}{l}3.7 \\
2.7 \\
2.9 \\
2.7 \\
2.4 \\
3.0 \\
2.9 \\
2.9\end{array}$ & $\begin{array}{l}4.9 \\
5.6 \\
4.6 \\
3.9 \\
3.7 \\
4.0 \\
4.9 \\
5.4\end{array}$ & $\begin{array}{r}0.6 \\
.6 \\
.4 \\
.7 \\
.6 \\
.6 \\
.7\end{array}$ \\
\hline $\begin{array}{l}\text { Mean } \\
\text { Standard deviation } \\
\text { Relative deviation (percent) }\end{array}$ & $\begin{array}{l}4.3 \\
.27 \\
6.3\end{array}$ & $\begin{array}{c}1.5 \\
10.7\end{array}$ & $\begin{array}{l}.9 \\
.08 \\
8.9\end{array}$ & $\begin{array}{c}2.9 \\
.37 \\
12.8\end{array}$ & $\begin{array}{c}4.6 \\
.69 \\
15.0\end{array}$ & $\begin{array}{l}.6 \\
16.7\end{array}$ \\
\hline
\end{tabular}

${ }^{1}$ U.S. Geol. Survey standard granite from Westerly, R.I.

2 U.S. Geol. Survey standard diabase from Centerville, Va.

TABLE 2.-Reproducibility of gold determinations, in parts per billion, on splits and composites of selected igneous rocks

\begin{tabular}{|c|c|c|c|c|c|c|c|c|c|c|c|c|}
\hline & \multicolumn{4}{|c|}{$\begin{array}{c}\text { Rhyolite } \\
\text { obsidian }^{1}\end{array}$} & \multicolumn{3}{|c|}{$\begin{array}{l}\text { Rhyolite } \\
\text { pumice }^{2}\end{array}$} & \multicolumn{3}{|c|}{$\begin{array}{l}\text { Rhyolite } \\
\text { obsidian }^{3}\end{array}$} & \multicolumn{2}{|c|}{$\begin{array}{c}\text { Quartz } \\
\text { monzonite }^{4}\end{array}$} \\
\hline & 1 & 2 & 3 & 4 & 1 & 2 & 3 & 1 & 2 & 3 & 1 & 2 \\
\hline 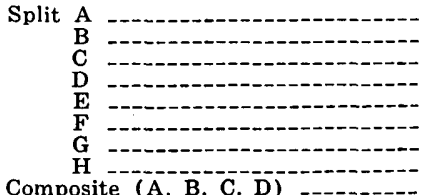 & $\begin{array}{r}0.3 \\
.2 \\
.5 \\
1.0 \\
-- \\
-- \\
--\end{array}$ & $\begin{array}{r}0.4 \\
.2 \\
.5 \\
.4 \\
-. \\
-- \\
--\end{array}$ & $\begin{array}{l}-- \\
-- \\
-- \\
-- \\
-- \\
-- \\
.3\end{array}$ & $\begin{array}{l}-- \\
-- \\
-- \\
-- \\
-- \\
--\end{array}$ & $\begin{array}{r}0.4 \\
.4 \\
.3 \\
.4 \\
-- \\
-- \\
-- \\
-\overline{5}\end{array}$ & $\begin{array}{r}0.8 \\
.3 \\
.5 \\
.4 \\
-- \\
-- \\
-- \\
.9\end{array}$ & $\begin{array}{r}0.7 \\
.2 \\
-\overline{.4} \\
-- \\
- \\
-- \\
--\end{array}$ & $\begin{array}{r}0.6 \\
.5 \\
.6 \\
.6 \\
.4 \\
.8 \\
-- \\
--\end{array}$ & $\begin{array}{r}0.5 \\
.5 \\
.6 \\
.7 \\
.5 \\
.8 \\
-- \\
--\end{array}$ & $\begin{array}{r}0.5 \\
.5 \\
.7 \\
.6 \\
-- \\
-- \\
-- \\
--\end{array}$ & $\begin{array}{r}0.3 \\
.3 \\
.3 \\
.3 \\
.3 \\
.5 \\
.2 \\
.3 \\
-.-\end{array}$ & $\begin{array}{r}0.3 \\
.3 \\
.4 \\
.2 \\
.3 \\
.3 \\
.2 \\
.5 \\
-.-\end{array}$ \\
\hline & .4 & .4 & .4 & .4 & .6 & .5 & $=$ & - & - & - & - & - \\
\hline $\begin{array}{l}\text { Grand mean } \\
\text { Standard deviation (percent) } \\
\text { Relative deviation }\end{array}$ & & 27. & & & & $\begin{array}{r}.5 \\
.19 \\
38.0\end{array}$ & & & $\begin{array}{l}.6 \\
.05 \\
3.3\end{array}$ & & 30.0 & \\
\hline
\end{tabular}

1 Sample 68-LGM, Little Glass Mountain. Medicine Lake Highland, Calif. Splits A, B, C, and D represent chips broken from various parts of a single hand specimen

${ }^{2}$ Samples 68-GM, Glass Mountain, Medicine Lake Highland, Calif. Samples A, B, C, and D represent four separate pumice fragments from bulk collection.

3 U.S. Geol. Survey standard RGM-1, Glass Mountain, Calif. (prepared by F. J, Flanagan, U.S. Geol. Survey).

'Sample 6K-306, Butte Quartz Monzonite, Boulder batholith, Montana. A single hand specimen was sawed into eight chunks, which when ground gave the following weights: A, $127 \mathrm{~g} ; \mathrm{B}, 90 \mathrm{~g} ; \mathrm{C}, 60 \mathrm{~g}$; $\mathrm{D}, 75 \mathrm{~g} ; \mathrm{E}, 100 \mathrm{~g} ; \mathrm{F}, 113 \mathrm{~g} ; \mathrm{G}, 84 \mathrm{~g}$; and $\mathrm{H}, 95 \mathrm{~g}$.

Tests on four selected rocks whose range of gold content $(0.3-0.6 \mathrm{ppb})$ is low and narrow suggest that the reproducibility of gold determinations differs little, regardless of differences in composition, texture, and grain size (rhyolite obsidian to coarsegrained quartz monzonite; see table 2 and fig. 1). Analysis of variance (single variable of classification) suggests that differences in mean gold content of splits of obsidian samples. are statistically significant at the 95-percent confidence level, where- as splits of pumice and quartz monzonite samples apparently have equal means. However, the separate chunks of pumice and the sawed pieces of the coarsegrained Butte Quartz Monzonite seem, from the analysis of variance, to have more homogeneous distribution of gold than do the obsidian samples (table 2 and fig. 1) ; this fact is contrary to our (intuitive) expectations and implies that many factors affecting overall precision have not been considered in our simple statistical test. 


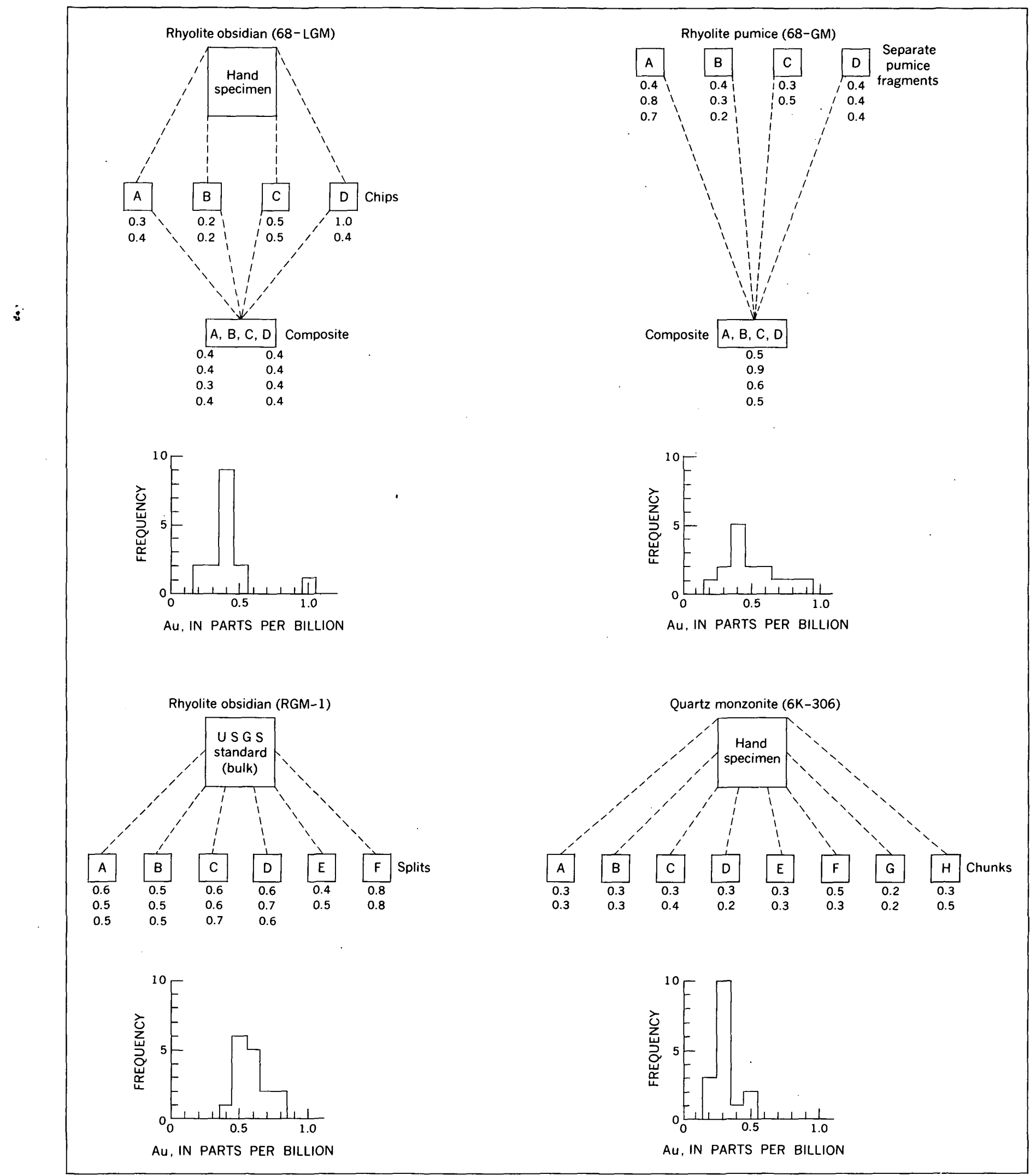

FIGURE 1.-Schematic representation of tests of reproducibility of gold determinations of three rhyolites and one quartz monzonite. Data from table 2. 
The principal factors that must be considered in evaluating the overall precision of the analytical result are:

1. Homogeneity of the sample, as it affects the sampling vagaries inherent in analyzing one or more 1 gram samples prepared from a much larger mass of rock. The problem of obtaining a representative sample which will contain an adequately representative amount of gold (in whatever form), or any other element of interest, has been treated by Wilson (1964) and Clifton, Hunter, Swanson, and Phillips (1969). However, in view of the lack of quantitative data regarding gold-particle size or specific mode of occurrence of gold in igneous rocks, it is not possible at this time to evaluate quantitatively the effect of variations in sample homogeneity on the observed overall precision. ${ }^{1}$

2. Analytical factors include errors in weighing, flux variation in the reactor (which may vary as much as 5 percent from the mean, when four monitors are used), and counting statistics (which may also vary as much as 5 percent, depending on count rates). Other analytical factors that may contribute to the problem are variations of a mechanical or physical nature, such as failure to achieve adequate or uniform mixing during fusion of sample, failure of active and inactive carrier to exchange isotopes completely, mechanical losses during fusion, and variations in position of samples during counting when automatic sample changers are operating.

Because of the large number of samples involved in this reconnaissance investigation, there obviously was not enough time to analyze each sample in replicate in an attempt to relate the relative contribution of sample homogeneity versus analytical error to the overall precision levels. However, we can place some conservative empirically derived limits on the "effective" or "working" precision of the data presented herein. Detailed studies on selected samples (tables 1 and 2) show that, when concentration levels are less than $1 \mathrm{ppb}$ gold, the standard deviation can be less than $0.1 \mathrm{ppb}$ and differences of $0.2 \mathrm{ppb}$ or greater between samples may be geochemically significant; for such small concentrations a low counting rate may have a significant effect. We have chosen intervals of $0.25 \mathrm{ppb}$ in the presentation of our data

\footnotetext{
1 For example, the quartz monzonite $(6 \mathrm{~K}-306)$ in table 2 has a mean gold content of $0.3 \mathrm{ppb}$, but another sample from the same outcrop collected several years earlier contains $0.8 \mathrm{ppb}$ gold (table 21).
}

in histogram form (fig. 1), even though we realize that in the generally nonreplicate routine, processing of the many hundreds of samples, differing in homogeneity, a more realistic standard deviation for any single determination is much greater than $0.1 \mathrm{ppb}$ and differences as great as $0.5 \mathrm{ppb}$ may not be geochemically or statistically significant.

At levels of gold concentration greater than $1 \mathrm{ppb}$ and for coarse-grained rocks which are likely to be more heterogeneous in gold distribution, we feel that differences of 20-25 percent probably represent geochemically significant variations. For reasonably homogeneous samples (for example, glassy or aphanitic rocks) which have been carefully processed, a precision of 10 percent can be expected, and values that differ from one another by more than 10 percent of the value can, we suggest, be considered as representing actual differences in gold content.

\section{ACCURACY}

The accuracy of an analytical method is more difficult to evaluate. It is generally evaluated by cross-comparison with results obtained independently by other investigators using different analytical techniques. Because few methods, other "than radioactivation, are suitable for gold determinations at low concentrations, we can only compare our data with other data mainly obtained by neutron-activation procedures. Rowe and Simon (1968, table 3) have shown the good agreement between data obtained on U.S. Geological Survey standard rocks by the method we used in this study and those obtained by other investigators.

\section{CONTAMINATION EFFECTS}

At low levels of gold concentration, the effects of contamination during sample preparation and handling can be significant. To study the magnitude of contamination effects, an experiment was performed. Z. S. Altschuler, U.S. Geological Survey, using careful splitting techniques, prepared four splits of a powdered sample of tonalite from the San Jacinto Mountains, Calif. From previous analysis it. was known that this sample contained about $2 \mathrm{ppb}$ gold. Two of the four splits were fingered, after first rubbing the fingers on a gold watch. The other two splits were analyzed directly without handling. The two "gold-fingered" splits gave results of 537 and $608 \mathrm{ppb}$ as compared with 1.0-1.9 ppb for the unhandled samples. This indicates the need for extreme care in handling samples when analyzing for trace elements in parts per billion. 
A major advantage of activation analysis is that it minimizes possible reagent and other contamination; contamination can only take place during sample collection, preparation, and weighing. After a sample has been sealed in its irradiation vial, it is free from nearly all possible contamination, aside from a sample mixup.

\section{GOLD CONTENT IN PLUTONIC ROCKS}

The spatial and (or) temporal association of gold mineralization and plutons has been noted in many parts of the United States and the world. (See, for example, Emmons, 1937; Koschmann and Bergendahl, 1968.) However, only relatively recently have there been attempts (for example, Voskresenskaya and Zvereva, 1968; Shcherbakov and Perezhogin, 1964; Shcherbakov, 1968; Shilin, 1968; Mantei and Brownlow, 1967; Mantei and others, 1970) to obtain precise measurements of gold in plutonic rocks known or supposed to be unaffected by postcrystallization alteration or metamorphism. In this study, we have analyzed about 160 samples representative of the dominant rocks of the major (MesozoicTertiary) batholiths of the Western United States, as well as of other smaller plutonic masses. These batholiths underlie vast areas (approximately 100,000 square miles) and are fairly typical of igneous rocks exposed in the earth's crust. Thus, the data obtained on these batholithic rocks are important for establishing the crustal abundance of gold.

The geologic settings of the batholiths and plutons we have sampled are, in general, well known and have been described copiously in the literature; table 3 summarizes some key references to literature pertinent to the samples analyzed. We shall make no attempt to discuss each of the plutonic provinces in detail, principally because gold content in all but a very few plutonic rocks varies only slightly from province to province. For convenience, our data on plutonic rocks are discussed in terms of two broad categories, calc-alkalic and alkalic. ${ }^{2}$

\section{CALC-ALKalic PROVINCES}

Calc-alkalic plutonic rocks, such as those making up the major batholiths of the Western United States, vary little in gold content; the overwhelming majority of samples have $3 \mathrm{ppb}$ or less of gold (tables 4, 18-23; figs. 2 and 3 ). From our data, the only noteworthy exception to this generalization is represented by the Southern California batholith,

\footnotetext{
2 These terms are used in this paper in a general petrologic sense, not in the specific nominal sense of Peacock (1931).
}

TABLE 3.-Selected literature pertinent to the plutonic samples analyzed

Suite or location

References

Southern California batholith_ Larsen (1948).

Larsen and Gottfried (1961).

Taylor and Epstein $(1962 \mathrm{a}, \mathrm{b})$.

Sierra Nevada batholith, California.

Bateman, Clark, Huber, Moore, and Rinehart (1963).

Bateman and Eaton (1967).

Dodge, Smith, and Mays (1969).

Coast and Transverse Ranges, Page (1966).

Calif.

Dodge and Ross (1971).

Idaho batholith, Idaho

Larsen and Schmidt (1958).

Boulder batholith, Montana

McDowell and Kulp (1969).

Tilling, Klepper and Obradovich (1968).

Doe, Tilling, Hedge, and Klepper (1968).

Knopf (1957).

Tatoosh pluton, Washington _- Fiske, Hopson, and Waters (1963).

Wright (1964).

Rocky Mountains, Colo

Lovering and Goddard (1950).

White Mountains Plutonic Series, New Hampshire

Chapman and Williams (1935).

(formerly named the White Mountains Plutonic-Volcanic

Billings (1928). Series).

TABLE 4.-Summary of distribution of gold in various plutonic provinces

[Data from tables 18-25]

\begin{tabular}{|c|c|c|c|c|}
\hline Suite or location & Rock type & $\begin{array}{l}\text { Number } \\
\text { of } \\
\text { samples }\end{array}$ & $\underset{(p p b)}{\text { Range }}$ & $\begin{array}{c}\text { Average } \\
\text { gold } \\
\text { content } \\
\text { (ppb) }\end{array}$ \\
\hline \multicolumn{5}{|c|}{ Calc-alkalic provinces } \\
\hline $\begin{array}{l}\text { Southern California } \\
\text { batholith. }\end{array}$ & $\begin{array}{l}\text { Gabbro } \\
\text { Tonalite } \\
\text { Granodiorite } \\
\text { Quartz monzonite to } \\
\text { aplite. }\end{array}$ & $\begin{array}{r}6 \\
9 \\
12 \\
3\end{array}$ & $\begin{array}{r}0.7-11.6 \\
.5-11.3 \\
.2-1.2 \\
1.3-1.9\end{array}$ & $\begin{array}{r}4.4 \\
3.7 \\
.4 \\
.9\end{array}$ \\
\hline $\begin{array}{l}\text { Sierra Nevada } \\
\text { batholith, California. }\end{array}$ & $\begin{array}{l}\text { Quartz diorite } \\
\text { Granodiorite } \\
\text { Quartz monzonite to } \\
\text { alaskite. }\end{array}$ & $\begin{array}{r}1 \\
11 \\
5\end{array}$ & $\begin{array}{l}.4-5.2 \\
.3-1.3\end{array}$ & $\begin{array}{r}1.4 \\
1.5 \\
.8\end{array}$ \\
\hline $\begin{array}{l}\text { Coast and Transverse } \\
\text { Ranges, Calif. }\end{array}$ & $\begin{array}{l}\text { Quartz diorite } \\
\text { Granodiorite } \\
\text { Quartz monzonite }\end{array}$ & $\begin{array}{l}1 \\
3 \\
1\end{array}$ & $.2-7$ & $\begin{array}{r}.5 \\
.5 \\
2.1\end{array}$ \\
\hline Idaho batholith _._. & $\begin{array}{l}\text { Diorite and quartz } \\
\text { diorite. }\end{array}$ & $\overline{7}$ & $.2-6.0$ & 2.2 \\
\hline & $\begin{array}{l}\text { Granodiorite } \\
\text { Quartz monzonite --- } \\
\text { Granite to aplite--- }\end{array}$ & $\begin{array}{r}16 \\
6 \\
6\end{array}$ & $\begin{array}{l}.1-5.2 \\
.4-2.7 \\
.2-\quad .8\end{array}$ & $\begin{array}{r}1.7 \\
1.1 \\
.5\end{array}$ \\
\hline $\begin{array}{l}\text { Boulder batholith, } \\
\text { Montana. }\end{array}$ & $\begin{array}{l}\text { Syenogabbro } \\
\text { Granodiorite } \\
\text { Quartz monzonite to } \\
\text { to alaskite. }\end{array}$ & $\begin{array}{r}1 \\
3 \\
25 \\
\end{array}$ & $\begin{array}{r}1.0-3.4 \\
.5-\quad .8\end{array}$ & $\begin{array}{r}.6 \\
.6\end{array}$ \\
\hline $\begin{array}{l}\text { Tatoosh pluton, } \\
\text { Washington. }\end{array}$ & Granodiorite -..--- & 15 & $.3-4.2$ & 1.3 \\
\hline $\begin{array}{l}\text { Rocky Mountains, } \\
\text { Colo. }\end{array}$ & $\begin{array}{l}\text { Quartz diorite to } \\
\text { granite. }\end{array}$ & 4 & $.4-\quad .6$ & .5 \\
\hline \multicolumn{5}{|c|}{ Alkalic provinces } \\
\hline $\begin{array}{l}\text { White Mountain } \\
\text { Plutonic Series, } \\
\text { New Hampshire. }\end{array}$ & $\begin{array}{l}\text { Gabbro to monzodio- } \\
\text { rite. } \\
\text { Syenite }\end{array}$ & 2 & $\begin{array}{r}0.3-0.3 \\
.3-\quad .4\end{array}$ & $\begin{array}{r}0.3 \\
.3\end{array}$ \\
\hline North Carolina & $\begin{array}{l}\text { Granite } \\
\text { Gabbro } \\
\text { Syenite } \\
\text { Albite quartz monzo- } \\
\quad \text { nite to granite. }\end{array}$ & $\begin{array}{r}21 \\
1 \\
1 \\
12\end{array}$ & $\begin{array}{l}.2-1.6 \\
-.2-2.3\end{array}$ & $\begin{array}{l}.6 \\
.7 \\
.2 \\
.9\end{array}$ \\
\hline
\end{tabular}

1 The altered granite (5.6 ppb) is excluded

2 One of the quartz monzonite samples is represented by the average value for 19 samples from a 4,000-foot borehole (table 14). 

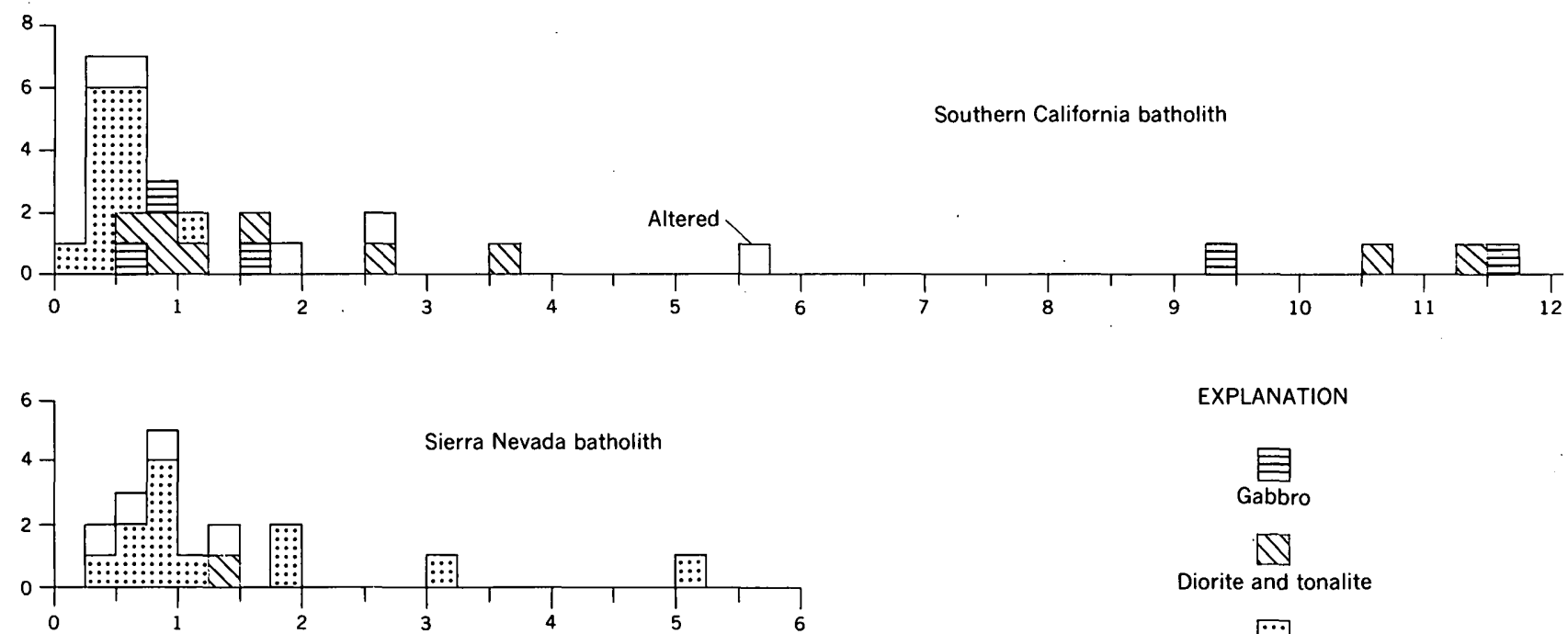

EXPLANATION
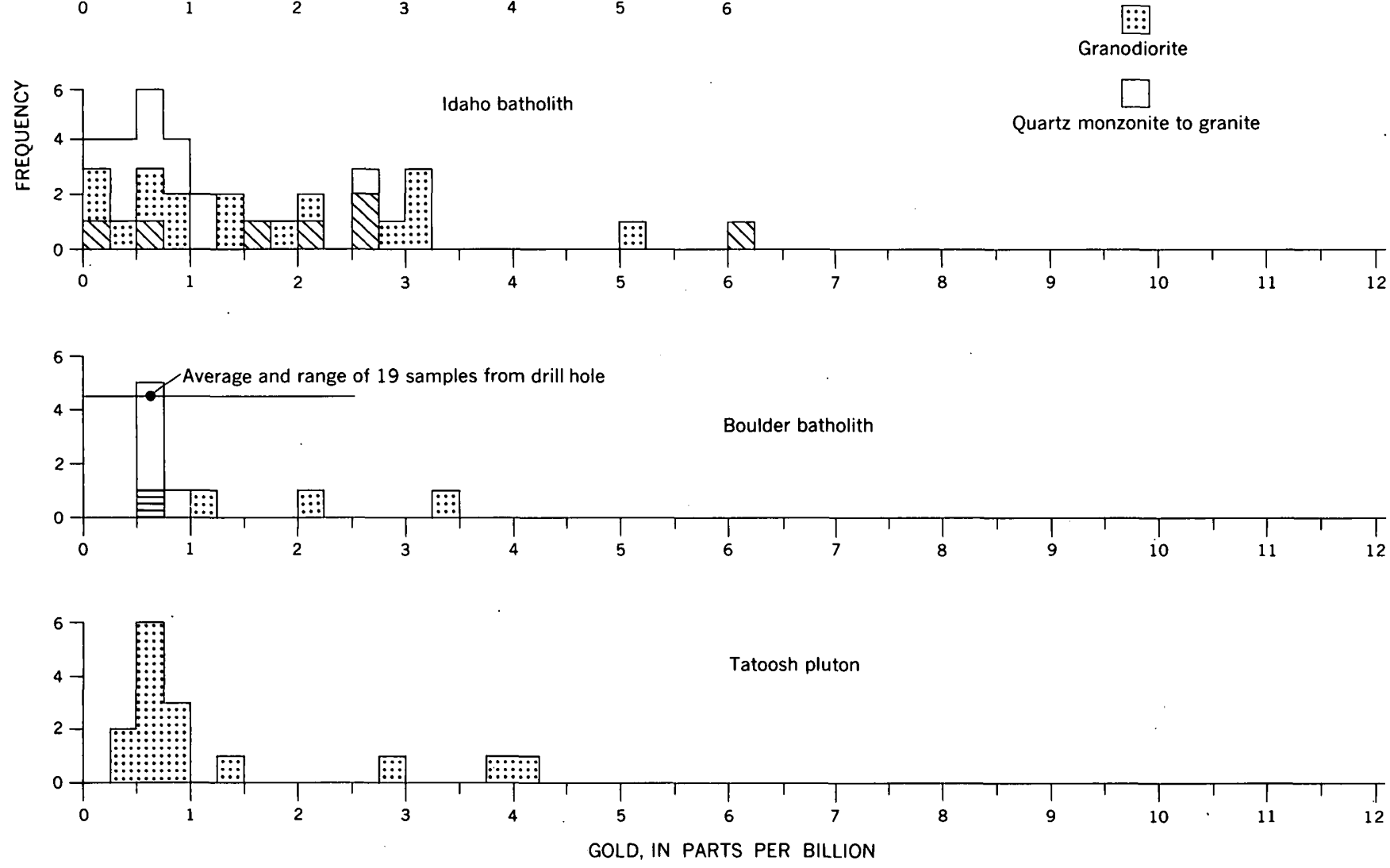

FIGURE 2.-Histograms of gold content of some plutonic rocks of the Western United States.

Data from tables 18-22.

some gabbroic phases of which, relative to other plutonic rocks studied, can have a comparatively high gold content, as great as almost 12 ppb (fig. 2; table 4).

Taken individually, plutonic suites (such as the Southern California, Idaho, Sierra Nevada and, perhaps, the Boulder batholiths) commonly exhibit a gross systematic variation of gold content with rock type (table 4). This tendency for the more mafic members in a given plutonic series to be higher in gold than the felsic members supports our earlier suggestion (Gottfried and others, 1969), based on fewer data, that gold apparently is not concentrated in residual liquids during magmatic differentiation. Table 5 shows the average gold content of some plutonic rocks, calculated according to rock type regardless of provenance; our data rather convincingly reinforce the pattern of increasing gold 


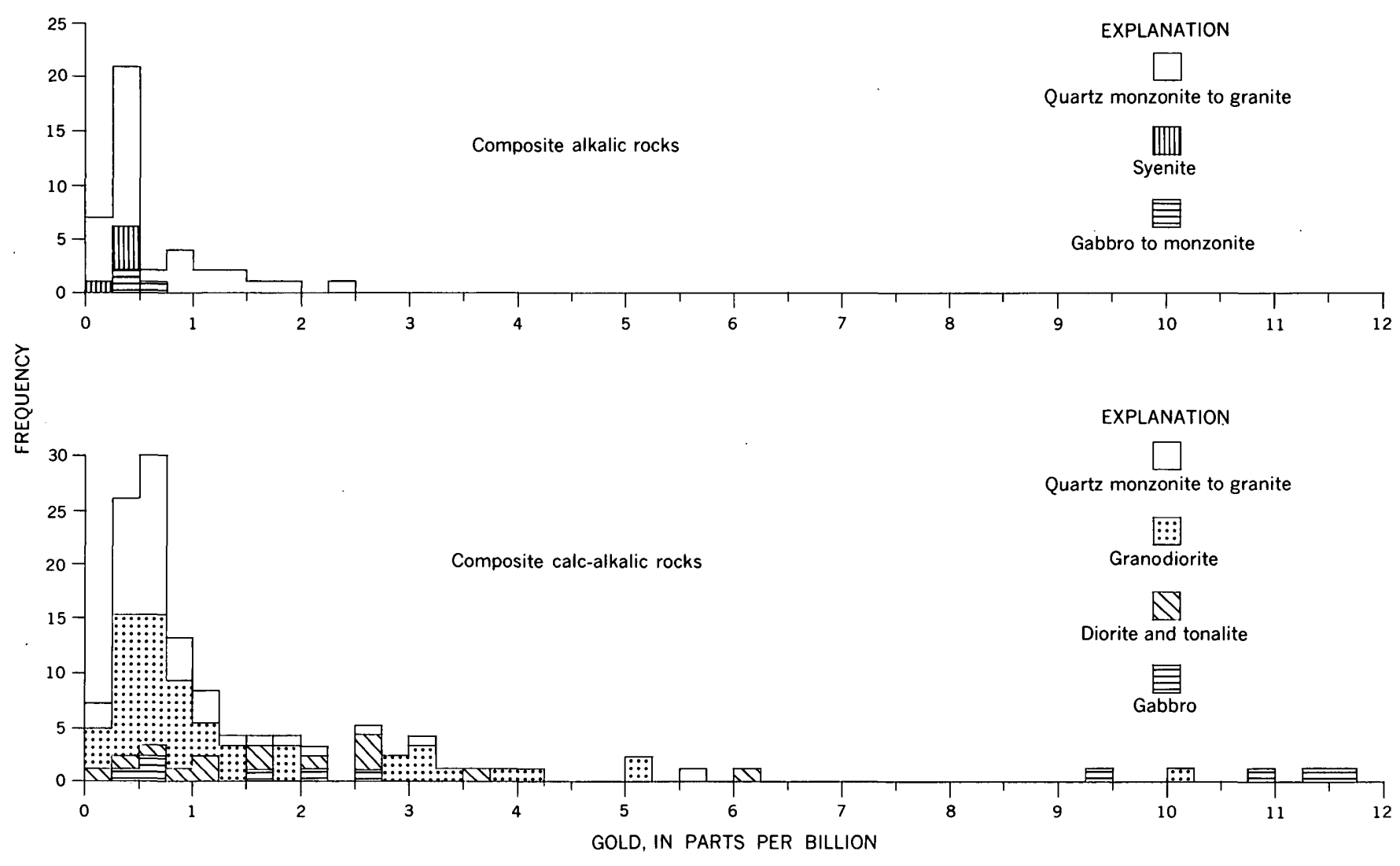

Figure 3.-Composite histograms of gold content of calc-alkalic and alkalic plutonic rocks; provenance not considered. Data from tables 18-25.

content with increasing content of mafic minerals, as suggested by data for individual suites. On the whole, our data are in good accord with the summaries of Phan (1965, table 1.4.1) and Jones (1969, table 5); their summaries are based on values in the literature, principally Russian (for example, Shcherbakov and Perezhogin, 1963, 1964). The question of the mode of occurrence of gold in some calc-alkalic plutonic rocks studied is taken up later.

TABLE 5.-Distribution of gold in calc-alkalic and alkalic plutonic rocks generalized according to rock type regardless of province

[Summarized from data of tables 18-25]

\begin{tabular}{|c|c|c|c|}
\hline Rock type & $\begin{array}{l}\text { Number } \\
\text { of } \\
\text { samples }\end{array}$ & $\begin{array}{l}\text { Range } \\
\text { (ppb) }\end{array}$ & $\begin{array}{l}\text { Average } \\
\text { gold } \\
\text { content } \\
(\text { ppb) }\end{array}$ \\
\hline \multicolumn{4}{|c|}{ Calc-alkalic plutonic rocks } \\
\hline $\begin{array}{l}\text { Gabbro } \\
\text { Diorite and tonalite } \\
\text { Granodiorite } \\
\text { Quartz monzonite to granite }\end{array}$ & $\begin{array}{r}7 \\
19 \\
60 \\
129\end{array}$ & $\begin{array}{r}0.6-11.6 \\
.2-11.3 \\
.1-5.2 \\
1.1-2.7\end{array}$ & $\begin{array}{r}3.9 \\
2.7 \\
1.2 \\
.8\end{array}$ \\
\hline \multicolumn{4}{|c|}{ Alkalic plutonic rocks } \\
\hline $\begin{array}{l}\text { Gabbro to monzodiorite } \\
\text { Syenite } \\
\text { Quartz monzonite to granite }\end{array}$ & $\begin{array}{r}3 \\
5 \\
33\end{array}$ & $\begin{array}{l}0.3-0.7 \\
.2-\quad .4 \\
.2-2.3\end{array}$ & $\begin{array}{r}0.4 \\
.3 \\
.7\end{array}$ \\
\hline
\end{tabular}

1 The value for altered granite $(5.6 \mathrm{ppb})$ from the Southern California batholith is excluded.

\section{ALKALIC PROVINCES}

Our sampling of alkalic plutonic rocks is limited to some rocks from New Hampshire, North Carolina, and South Carolina (table 24 and 25). Nonetheless, the data suggest that gold content for the alkalic rocks studied occurs within a lower and even narrower range than for the calc-alkalic rocks studied and rarely exceeds $1.5 \mathrm{ppb}$ (table 5 and fig. 3). This apparent relationship is also observed for volcanic rocks (p. 19). Our data for alkalic plutonic rocks are insufficient to establish any statistically significant figures on the systematic variation of gold content with rock type, as could be demonstrated for the calc-alkalic rocks.

\section{GOLD CONTENT IN BASALTIC ASSOCIATIONS OCEANIC PROVINCES \\ HAWAIIAN ISLANDS}

Gold content was determined in 33 samples of volcanic rocks representing some of the major petrographic provinces of the Hawaiian Islands (table 6 and fig. 4). Petrochemical characteristics and geologic setting of these suites are well known. (See, 
TABLE 6.-Summary of gold content in basaltic associations [Data from tables 26-33]

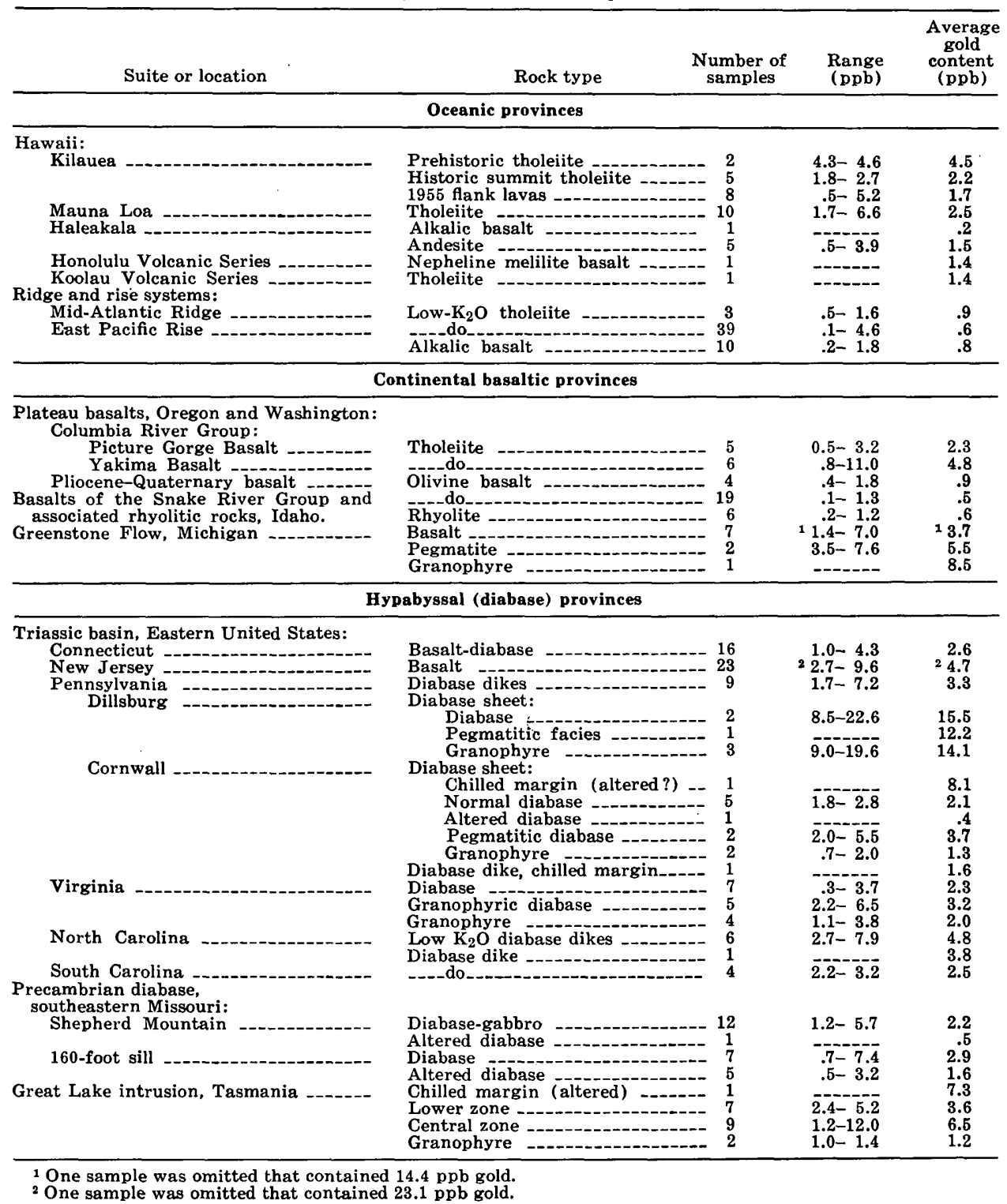

for example, Powers, 1955; Macdonald, 1949 ; Macdonald and Powers, 1946; Macdonald and Eaton, 1964 ; Tilley and Scoon, 1961.) Most of our analyses are on glassy silica-saturated basalts of Kilauea and Mauna Loa which are believed to be fairly representative of magmas that formed the lavas of the primitive shield of each of these volcanoes.

Samples of the tholeiite that erupted from the summits of Kilauea and Mauna Loa (table 26) are quite uniform in gold content and average 2.2 and $2.5 \mathrm{ppb}$, respectively. The values for Mauna Loa basalts agree reasonably well with those obtained by Ehmann, Baedecker, and McKown (1970), who reported an average of $4.2 \mathrm{ppb}$ for three samples, and by Vincent and Crocket (1960b), who obtained a value of $2.6 \mathrm{ppb}$ on a single sample. The moderately fractionated 1955 lavas of the east rift zone and those of the alkalic Haleakala suite appear to have a gold content slightly lower than those of typical Hawaiian tholeiites (table 26).

\section{MID-ATLANTIC RIDGE AND EAST PACIFIC RISE}

The worldwide ridge-and-rise system is one of the prominent features of the ocean floor. Basalt, commonly referred to as oceanic tholeiite, is by far the predominant rock type of this feature. Oceanic tholeiitic basalts are readily distinguished from most continental basalts by their lower potassium content $(<0.3$ percent), unusually low abundances of large ions, such as thorium, uranium, niobium, 

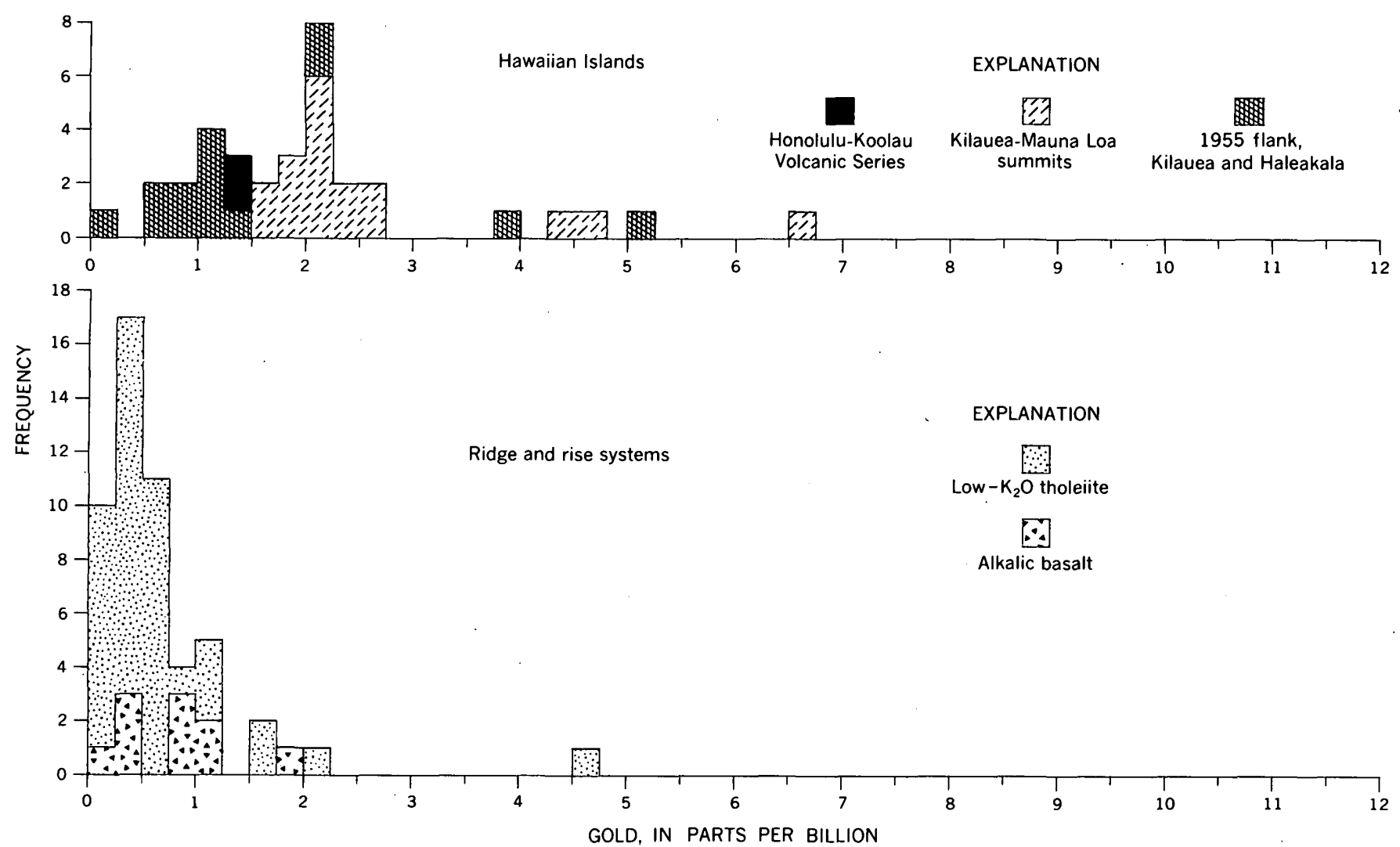

FIGURE 4.-Histograms of gold content of rocks in some basaltic associations from oceanic provinces. Data from tables 26 and 27.

rubidium, barium, and cesium, and high potassiumrubidium and potassium-cesium ratios (Engel and others, 1965; Tatsumoto and others, 1965; Gast, 1965; Gottfried and others, 1968). Alkalic basalts, which make up less than 1 percent of oceanic volcanic rocks, occur on the flanks of the oceanic ridges, on the tops of submarine volcanoes, and on the islands located on the ridge-and-rise system.

Among the 52 samples (table 27) we analyzed are some previously studied by Engel, Engel, and Havens (1965) from widely separated regions as well as a larger number of samples (35) from a restricted segment (Juan de Fuca ridge-Blanco fracture zone) of the East Pacific Rise. Gold content of tholeiitic rocks is rather uniform and averages slightly less than $1 \mathrm{ppb}$; contrary to expectation, the alkalic basalts, which average $0.8 \mathrm{ppb}$ (table 6), have virtually the same gold content as tholeiites.

Previously published values for gold in oceanic tholeiites are few and contradictory. DeGrazia and Haskin (1964) reported 6.3-14 ppb gold for three samples from the Mid-Atlantic Ridge, whereas Ehmann, Baedecker, and McKown (1970) obtained only $0.2-0.3 \mathrm{ppb}$ for the same three samples. and 0.4 ppb for a sample from the East Pacific Rise. Our more extensive data, though still far from adequate considering the vast areas underlain by oceanic ridges, suggest that oceanic tholeiites are characterized by lower gold content than typical tholeiitic basalts from Hawaii or continental regions.

\section{CONTINENTAL PROVINCES}

PLATEAU BASALTS AND ASSOCIATED ROCKS, OREGON AND WASHINGTON

Waters (1961) subdivided the basalts of the Columbia River Group (Miocene and Pliocene) into two types (there do not seem to be any transitional varieties): (1) Picture Gorge type-older, silica content 47-50 percent, approximately 5 percent olivine and (2) Yakima type-younger, silica content 53-54 percent, higher $\mathrm{K}_{2} \mathrm{O}$ and $\mathrm{TiO}_{2}$, little or no olivine. However, gold content observed for these rocks (table 28) does not reflect their differences in chemistry and mineralogy. Because of the limited number of samples analyzed and the wide variation in range of gold values, the differences in average gold content between the Picture Gorge 

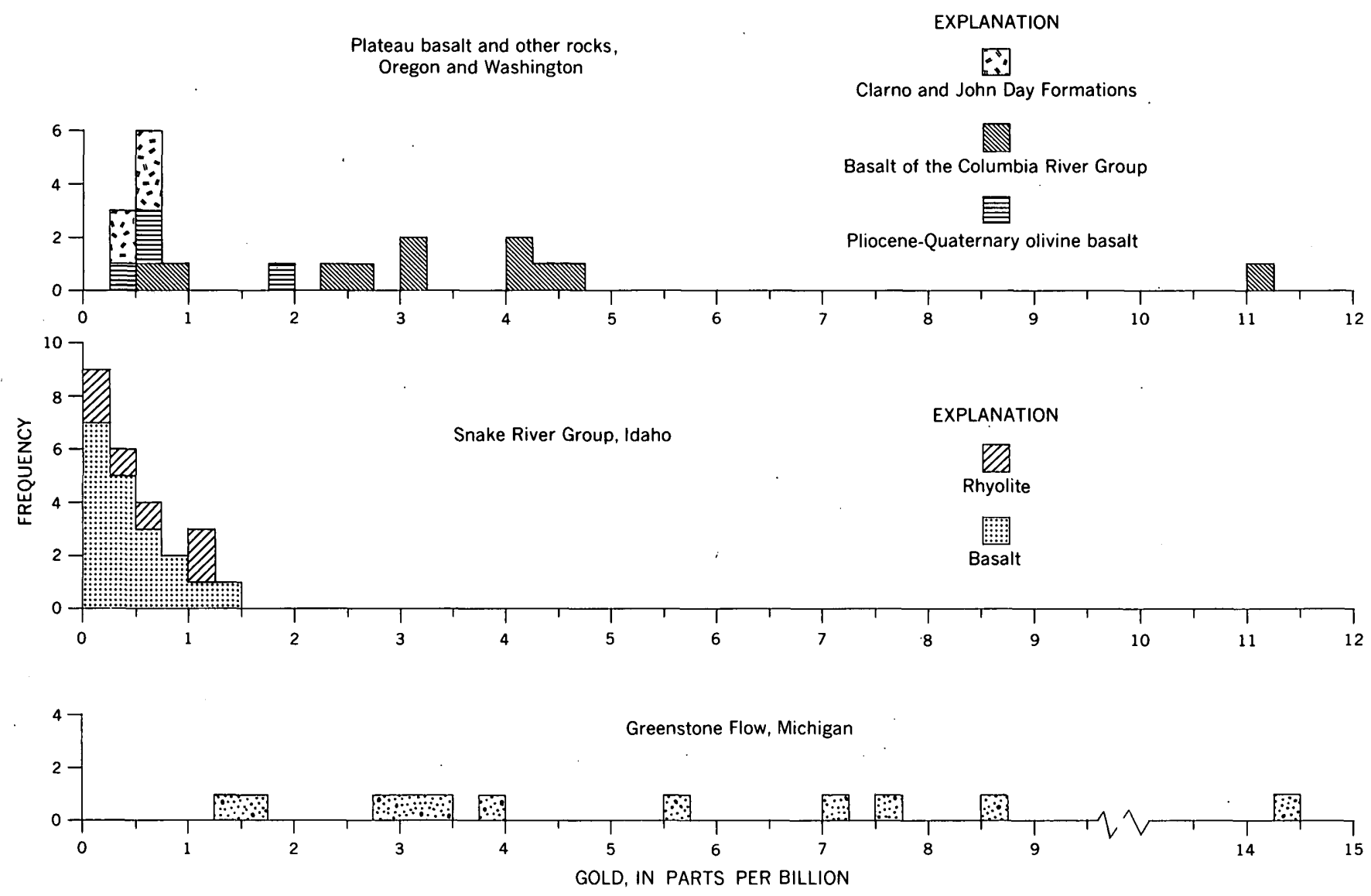

Figure 5.-Histograms of gold content of rocks from some continental basaltic provinces of the United States. Data from tables 28-30.

(2.3 ppb) and Yakima (4.8 ppb) types may not be statistically significant.

The Pliocene-Quaternary basalts differ from the Columbia River basalts in having more plagioclase and olivine and a diktytaxitic texture. Our limited data suggest that gold content in these rocks is lower than that in most Columbia River basalts and comparable to that in the andesites and in the more silicic rocks of the Clarno and John Day. Formations (tables 6 and 28; fig. 5).

\section{BASALTS OF THE SNAKE RIVER GROUP AND ASSOCIATED RHYOLITIC ROCKS, IDAHO}

Powers (1960a) has shown that the Snake River basalts of southern Idaho are lower in $\mathrm{SiO}_{2}$ and richer in $\mathrm{FeO}, \mathrm{TiO}_{2}$, and $\mathrm{P}_{2} \mathrm{O}_{5}$ than basalts of the Columbia Plateau or Cascade Range. The occurrence of strongly alkaline mafic lavas (Powers, 1960b) and alkalic rhyolites and tuffs indicates that Snake River basalts have alkalic affinities. An unusual chemical feature of these rocks is the decrease of the iron-magnesium ratio with an increase in silica, a trend opposite to that for tholeiitic suites. Intermediate rocks such as andesites and dacites are extremely rare in the Snake River Plain, regarded by Hamilton (1965) as a province of bimodal volcanism of olivine basalt and rhyolite.

Of the 19 basalts analyzed, only two exceed $1 \mathrm{ppb}$ in gold (table 29); the rhyolites and basalts have about the same range and mean in gold content (table 6 and fig. 5 ).

\section{GREENSTONE FLOW, MICHIGAN}

Because the Greenstone Flow is the thickest and most differentiated of the Keweenawan flows in the Michigan copper district, it has been studied in considerable detail by Broderick (1935) and by Cornwall (1951a, b, c). The flow is composed of ophitic olivine basalt that contains pegmatitic layers and small granophyre dikes in its upper half. Because of the close spatial relationship of the basaltic flows and copper deposits, the abundance and distribution of copper in the Greenstone and other flows have been well documented by much geologic 
and analytical data (Broderick, 1935; Broderick and Hohl, 1935; Sandell and Goldich, 1943; Cornwall and Rose, 1957). These data suggest that, during magmatic differentiation, copper was concentrated in the pegmatitic facies of the Greenstone Flow.

Gold abundance of the same specimens (table 30) used by Cornwall and Rose (1957) in their spectrographic study shows no close systematic variation with stratigraphic position or copper content but nonetheless fits the gross positive correlation with copper, a chalcophilic element (see fig. 10). Despite some variability probably in part ascribable to varying degrees of alteration (noted by Cornwall, 1951a), gold content of the Greenstone Flow averages $3.7 \mathrm{ppb}$, which is similar to the mean gold abundance of most other basaltic provinces (table 6 ).

\section{hYPABYSSAL (DIABASE) PROVINCES}

In certain continental areas, rocks of basaltic composition occur predominantly as gently dipping or flat, intrusive diabase sheets, though they are also commonly associated with subordinate basaltic flows, plugs, and dikes. We have arbitrarily treated these basaltic or diabase sheets as another manifestation of basaltic volcanism, mainly because the undifferentiated (chilled) magma of these sheets is tholeiitic. Some sheets, especially those which have associated granophyres, are of particular geochemical and petrologic interest in that they provide unequivocal examples of differentiation in place of a given increment of basaltic magma.

\section{TRIASSIC BASIN, EASTERN UNITED STATES}

Basaltic rocks of Late Triassic age near the eastern margin of the United States and Canada occur as flows, small dikes, and thick intrusive sheets in down-faulted basins from Nova Scotia to South Carolina; these rocks underlie approximately 6,000 square miles. Early petrologic studies on samples from the northern part of the province (New Jersey and Pennsylvania) show that the undifferentiated magma (chilled margin) is of the tholeiitic magma type and fairly typical of continental tholeiitic provinces the world over (Walker, 1940; Hotz, 1953). However, recent petrochemical investigations (Ragland and others, 1968) of chilled margins of dikes in North Carolina indicate that, with few exceptions, these rocks more closely resemble oceanic tholeiites. Thus, at least two chemically different basaltic magmas may be represented by the Triassic mafic rocks.
Although the basalt-diabase samples we analyzed range fairly widely in texture and composition, the concentrated level and mean gold content (1.3-4.7 $\mathrm{ppb}$ ) for the various suites show relatively little variation, if the Dillsburg suite and the altered diabase from Cornwall are excluded (table 6 and fig. 6). For example, dike rocks from the North Carolina Piedmont (except for sample JY-1) are low in $\mathrm{SiO}_{2}$ (47-49 percent) and $\mathrm{K}_{2} \mathrm{O}$ (nearly equal to 0.2 percent $)$, are high in $\mathrm{Al}_{2} \mathrm{O}_{3}(\sim 16.9$ percent $)$, and average $4.8 \mathrm{ppb}$ gold; sample JY-1, though higher in $\mathrm{SiO}_{2}$ (52 percent) and $\mathrm{K}_{2} \mathrm{O}$ (0.5 percent), is not significantly different in its gold content $(3.8 \mathrm{ppb})$. Chemical data are not available for dike samples from South Carolina, which average 2.5 ppb gold. Within the Carolinas province, then, the mean gold content varies only within a factor of two, despite much greater differences in chemistry of the magmas. In contrast, and perhaps significantly, gold content in low- $\mathrm{K}_{2} \mathrm{O}$ diabase dikes of North Carolina is about five times that in nearly chemically identical tholeiitic basalts of the oceanic ridge system.

Relative to the other basalt-diabase suites analyzed, the Dillsburg suite (Pennsylvania) is considerably higher in gold content, which ranges from 8.5 to $22.6 \mathrm{ppb}$ and shows no apparent variation with bulk chemistry or stratigraphic position. It should be mentioned, however, that these samples are restricted to about the upper third of the sheet which is believed to be at least 1,000 feet thick; thus, in using the present data, we do not know if the entire sheet is characterized by a high gold content. Nevertheless, the average gold content in 12 samples (table 31 ) from the Cornwall district, Pennsylvania, located only approximately 30 miles to the east of Dillsburg in a similar geologic setting, is significantly lower $(0.4-8.1 \mathrm{ppb})$. The maximum gold content of $8.1 \mathrm{ppb}$ for the Cornwall samples is observed for a sample of the chilled margin, which contains very small sulfide veinlets; the presence of veinlets suggests that this one high value may reflect later introduction, rather than the original amount in the magma. In brief, the gold content in the Cornwall samples is significantly lower than those in petrographically equivalent rocks from the Dillsburg intrusion but is comparable to "background levels" typified by basalts and smaller dikes elsewhere in the Triassic hypabyssal basalt-diabase province.

For comparison with the differentiated diabase sheets at Cornwall and Dillsburg, Pa., gold analyses were made on 16 samples representative of the 

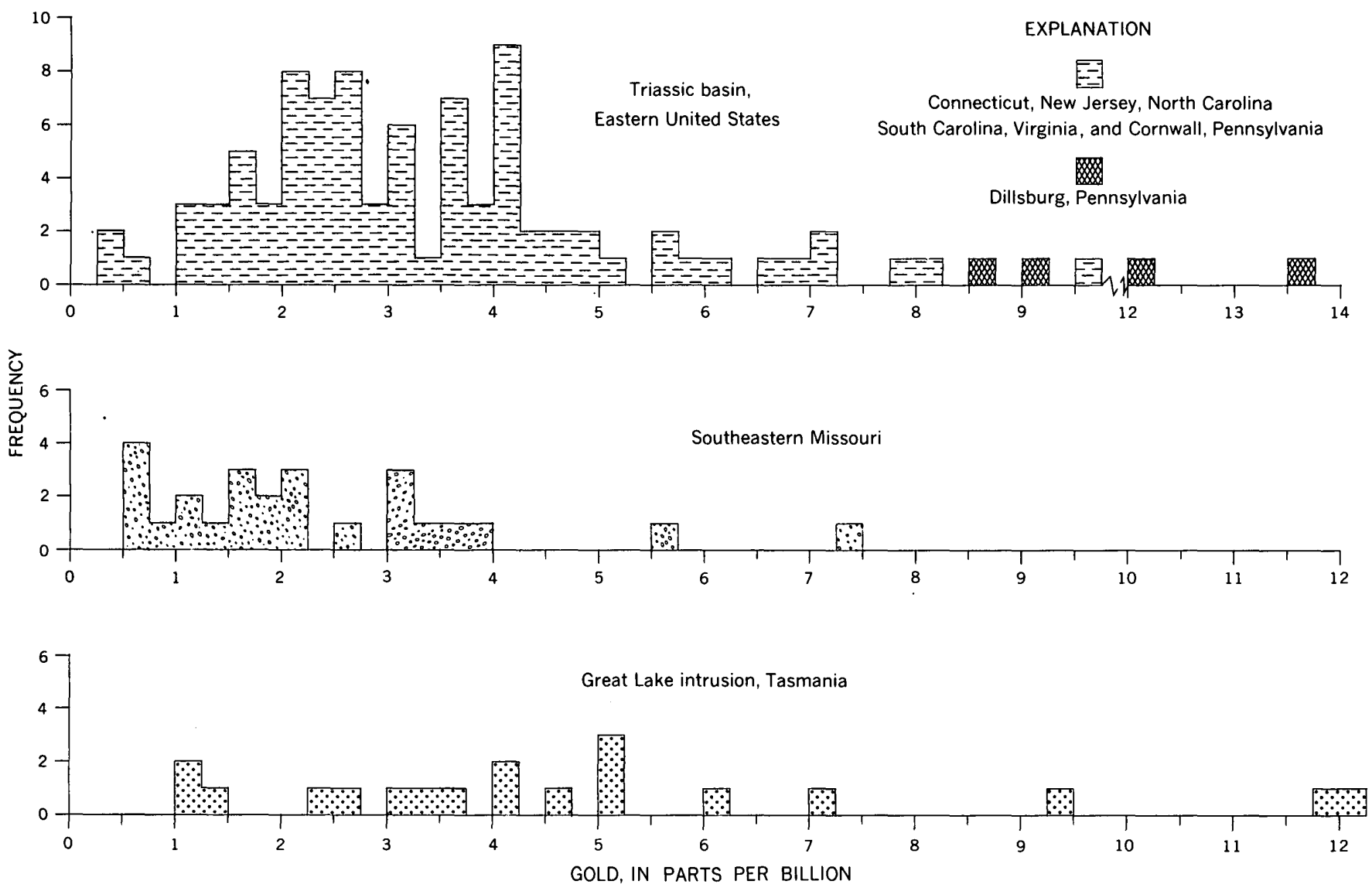

FIGURE 6.- Histograms of gold content of rocks from some hypabyssal (diabase) provinces of the United States and Tasmania. The diagrams for the Triassic basin, United States, does not show a sample from New Jersey, which has 23.1 ppb gold, and two samples from Dillsburg, Pa., which have 19.6 and $22.6 \mathrm{ppb}$ gold. Data from tables 31-33.

diabase-granophyre intrusions in Fairfax County, Va. Here, mineralization is lacking, and, hence, conditions are probably more favorable for establishing the primary gold content of diabasic rocks. Although widely ranging in mineralogic composition, the various phases of the diabase-granophyre association are strikingly uniform in gold content, and the means range only between 2.0 and $3.2 \mathrm{ppb}$ (table 6) ; chemical data are not available for these rocks. Such uniformity suggests that differentiation processes have affected gold content in these samples only minimally and such that the values observed may well be close to those of the parent magma. Vincent and Crocket (1960a) also noted the general constancy of gold content in rocks of the strongly fractionated Skaergaard intrusion in east Greenland.

The close similarity in gold content between the Virginia samples and fresh samples from the dikes and differentiated diabase sheet at Cornwall, $\mathrm{Pa}$, provide indirect evidence that the anomalously high gold content observed for the Dillsburg intrusion reflect postcrystallization alteration rather than primary features. Moreover, inasmuch as both the Cornwall and the Dillsburg intrusions are associated with mineralization, both these areas will be discussed in some detail in connection with the possible effects of alteration on primary gold distribution (p. 27).

\section{PRECAMBRIAN DIABASE, SOUTHEASTERN MISSOURI}

Borehole samples from two small differentiated mafic bodies in southeastern Missouri (table 32) have a gold content typical of other continental basalt-diabase samples; unaltered specimens have a mean gold content of 2.2-2.9 ppb (table 6). The geologic setting and petrologic studies of the specimens we analyzed have been described by Desborough $(1963,1967)$; the least differentiated rock of these bodies is an olivine diabase and is presumed to represent the parent magma. In both the Shepherd Mountain intrusion and the 160-foot sill, the altered rocks seem to have a lower gold content than the fresh (table 32), a tendency suggesting the pos- 

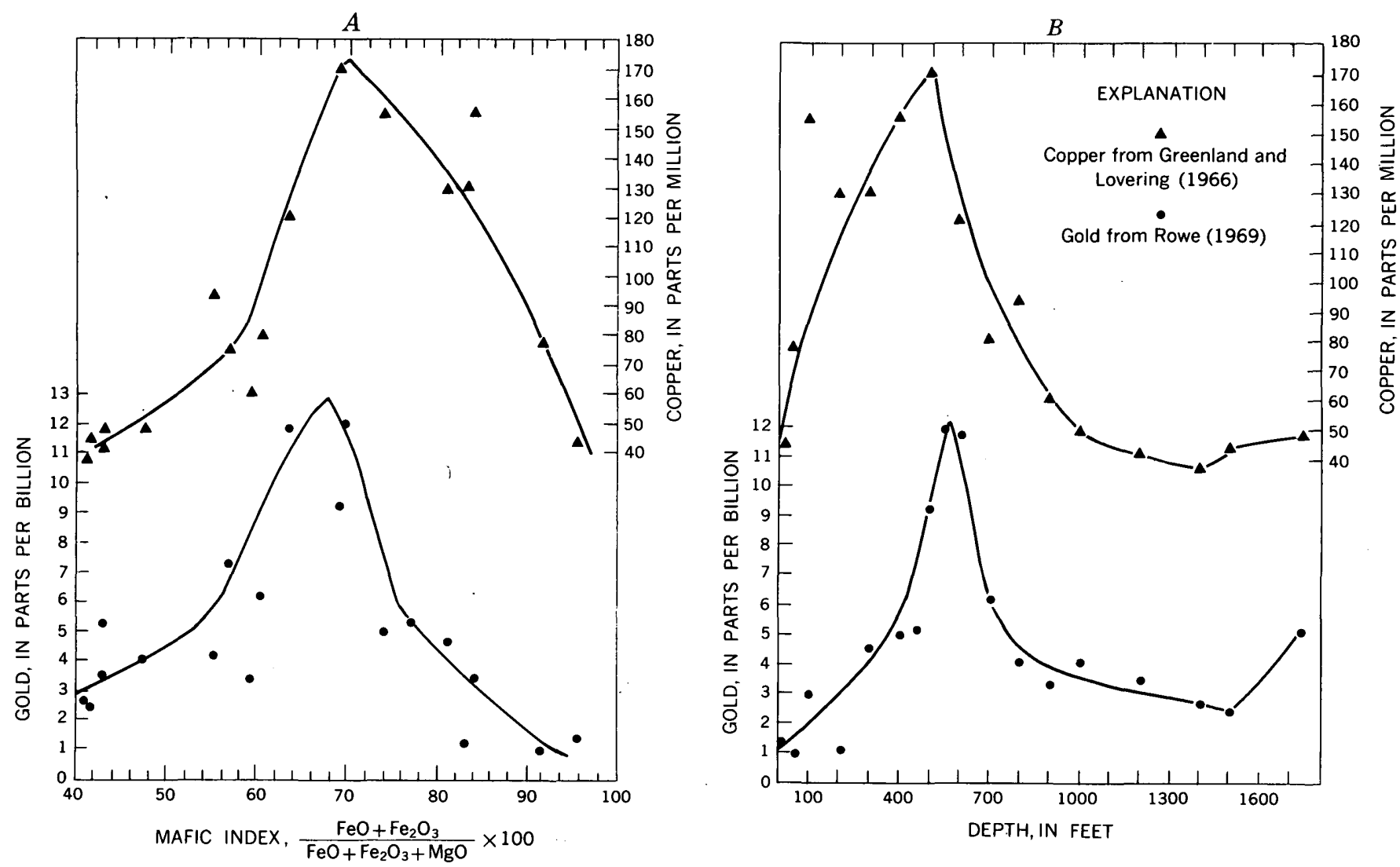

FiguRE 7.-Variation in gold and copper abundance with mafic index $(A)$ and depth $(B)$ of samples from the Great Lake sheet, Tasmania. Data from Greenland and Lovering (1966) and Rowe (1969).

sibility that some gold may have been removed during alteration; in view of the limited number of altered samples (six), this suggestion obviously needs to be tested by much additional data. Despite the fivefold increase in the amount of sulfides with differentiation (Desborough, 1967), our abundance data on gold show no such corresponding variation with total sulfides. From the findings of Vincent and Crocket (1960a) that gabbros rich in copper sulfides have a relatively high content of gold, we anticipated closer correlation between gold and sulfide abundance.

\section{GREAT LAKE INTRUSION, TASMANIA}

On the basis of comparative detailed petrologic, chemical, and mineralogic studies, McDougall (1964) considered the Great Lake intrusion to be an excellent representative of the Tasmanian tholeiitic province, which is Jurassic in age and underlies an area of some 6,000 square miles. In addition to McDougall's comprehensive work, abundant subsequent isotopic and trace-element investigations have been carried out on this intrusion; these studies make it perhaps one of the most extensively documented diabase-granophyre bodies (Heier and others, 1965; Greenland and Lovering, 1966 ; Gottfried and others, 1968).

Analyses for gold (Rowe, 1969) and copper (Greenland and Lovering, 1966) of 19 borehole specimens from the Great Lake sheet, in contrast to previously discussed differentiated diabasic intrusions, demonstrate a remarkably close correlation between gold and copper over the entire range of crystallization (table 33 ; fig. 7 ). The maximum gold content $(12 \mathrm{ppb})$ is in the lower part of the central zone, and the minimum gold content $(1.2 \mathrm{ppb})$ is in the granophyre. The gold content of the lower chilled margin is higher $(7.3 \mathrm{ppb})$ than the average for the intrusion and is probably due to hydrothermal introduction. Significantly, McDougall and Lovering (1963) and McDougall (1962) reported the crystallization of chalcopyrite during the middle stage of crystallization (central zone), which resulted in a strong depletion of copper in the later differentiates (granophyres). This close parallelism of gold and copper variation patterns may in large part reflect the abundance and composition of copper-rich sulfides, for example, chalcopyrite. Pre- 
liminary experimental data of P. B. Barton (in U.S. Geological Survey, 1969, p. A108) indicate that at $650^{\circ} \mathrm{C}$ chalcopyrite can accommodate more than 1.6 weight percent of gold, whereas amounts soluble in pyrite, pyrrhotite, and arsenopyrite are considerably less than 0.1 weight percent. However, Barton stressed that much of the gold is exsolved upon cooling.

The Great Lake sheet may be somewhat unusual (but ideal for study) in that virtually all variation trends of trace elements plot very smooth curves, including the trend for cesium, a highly mobile constituent that responds readily to the slightest postcrystallization disturbance (Gottfried and others, 1968). Moreover, the potassium-cesium ratio and content of volatiles (fluorine and chlorine) also vary systematically with differentiation (Greenland and Lovering, 1966). Collectively, these studies provide convincing evidence that any alteration in the Great Lake intrusion is local, that the degree of alteration is small, and that the observed variation patterns at major and minor elements record responses to changes in the primary crystallization regime. Thus, it is probably not at all fortuitous that the least disturbed diabase-granophyre system should demonstrate such a well-defined copper-gold relationship after undergoing magmatic differentiation.

\section{GOLD CONTENT IN BASALT-ANDESITE-RHYOLITE ASSOCIATIONS}

CAlC-ALKALIC PROVINCES

CASCADE RANGE AND ADJACENT AREAS, OREGON AND CALIFORNIA

Volcanic rocks in the Cascade Range, which extends from southern British Columbia to northern California, are generally grouped into two major sequences: (1) a sequence (Miocene or older) which underlies the Western Cascade Range and consists of folded and locally altered flows and pyroclastic material and (2) a younger sequence (Pliocene to Holocene) which underlies the High Cascades and consists chiefly of undeformed, fresh basaltic and andesitic flows.

Samples from the Western Cascades (Oregon) studied by Peck, Griggs, Schlicker, Wells, and Dole (1964) have an average gold content ranging from 0.9 to $7.2 \mathrm{ppb}$; there is a strong tendency for the basalts and andesites to be higher in gold than the dacites and rhyodacites (table 34). As representatives of the High Cascades and vicinity (California), 26 samples from the Mount Shasta, Lassen, and Medicine Lake regions have been analyzed (table 35). Chemical, mineralogic, and strontiumisotope data on most of these samples have been reported recently (Smith and Carmichael, 1968; Peterman and others, 1970). In general, the range in gold abundance and the mean gold content observed for samples from the Mount Shasta and Lassen regions are greater than the range and mean for samples from the Medicine Lake Highland region (table 7 and fig. 8).

Basalts analyzed from the Medicine Lake Highland range in age from the Pliocene Warner Basalt of Russell (1928) to the very recently erupted Modoc and Hat Creek Basalts of Powers (1932) and Anderson $(1940,1941)$. The Warner Basalt, which is also readily distinguishable from the Modoc Basalt by its significantly lower potassium content, averages slightly higher in gold than the Modoc Basalt, $3.5 \mathrm{ppb}$ as compared with $1.2 \mathrm{ppb}$; both these basalts, however, have more gold than rhyolites $(0.5 \mathrm{ppb})$ from the same region (table 7$)$. Though not from the Cascade volcanic province proper, rhyolitic rocks from Mono County, Calif., are also low in gold; excluding the sample containing $1.9 \mathrm{ppb}$ gold, the remaining seven samples have $0.5 \mathrm{ppb}$ or less gold (table 36 ).

Quartz basalts of the Lassen region have been considered as hybrid products resulting from the contamination of basaltic magma by felsic xenoliths and xenocrysts of dacitic origin (Finch and Anderson, 1930). The gold content of these rocks tends to be relatively high, an average of $11.9 \mathrm{ppb}$ (table 7 ). Because our data indicate that gold content in felsic volcanic rocks is lower than in mafic volcanic rocks in the Cascade province, the initial gold concentration in the host basaltic magma prior to contamination must have been even higher.

\section{JEMEZ MOUNTAINS, N. MEX.}

The Jemez Mountains of north-central New Mexico are composed of a complex volcanic pile that underlies an area of about 1,500 square miles and consists chiefly of lower to upper Pliocene basaltic, andesitic, dacitic, and rhyolitic rocks. The youngest volcanic rocks in the region are Pleistocene rhyolitic ash flows, which preceded caldera collapse, and postcaldera rhyolitic pyroclastics, flows, and domes (Ross and others, 1961; Smith and Bailey, 1968; Smith and others, 1970). Analysis of 46 samples shows the basalts to have distinctly higher gold content (averaging $2.5 \mathrm{ppb)} \mathrm{than} \mathrm{rhyolitic} \mathrm{rocks,}$ which, with very few exceptions, contain only a few tenths part per billion (table 37 ).

Samples of air-fall pumice and associated ashflow tuffs representing the Bandelier Tuff provide 
TABLE 7.-Summary of gold content in basalt-andesite-rhyolite associations [Data from tables 34-44]

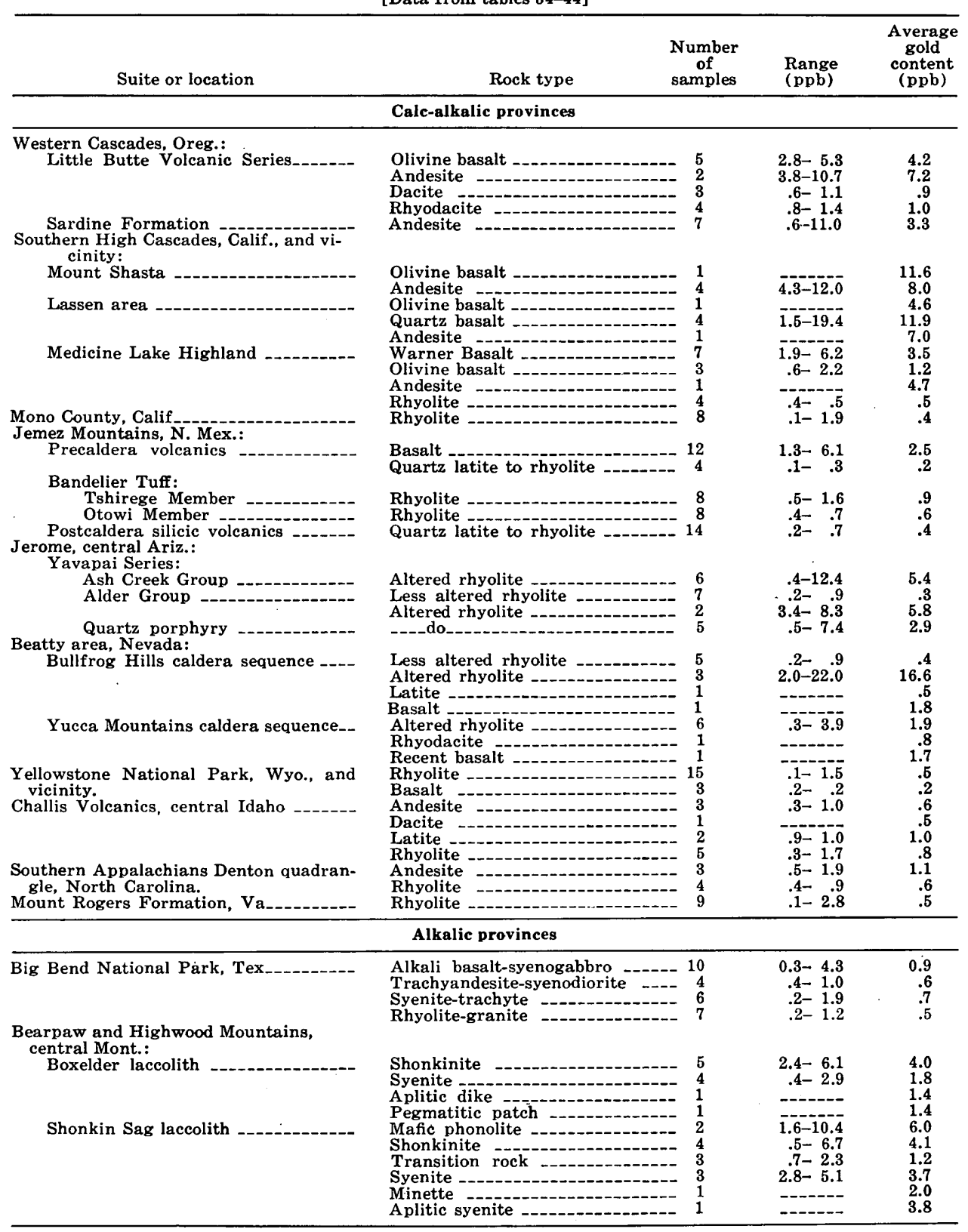

excellent material for tracing the behavior of gold during the course of differentiation of rhyolitic magma. This unit has been divided by Bailey, Smith, and Ross (1969) into two members, the Otowi and Tshirege, which have been dated as 1.4 m.y. (million years) and 1.0 m.y., respectively (Doell and others, 1968). Available data on mineralogy and on major and minor elements for successive flows of each member exhibit systematic variation trends which reflect corresponding physicochemical changes in their respective magma chambers (Smith and Bailey, 1966). The striking uniformity of gold con- tent within each member of the Bandelier Tuff suggests that, within the limits of analytical uncertainty, processes which produced wide variations in the lithophilic trace elements do not affect gold distribution. For the same samples, data on niobium, tantalum, thorium, uranium, rubidium, and cesium content (Smith and Bailey, 1966; Gottfried and others, unpub. data) shows a threefold to fourfold decrease from the first (most silicic) to the last (most mafic) erupted material, whereas gold content remains virtually constant (table 7 and fig. 8) ; similarly, the postcaldera rhyolites are uniformly 
low in gold content and exhibit no correlation with eruptive sequence or petrochemical features (table 37).

\section{YELLOWSTONE NATIONAL PARK, WYO., AND VICINITY}

Rhyolites of Pliocene and Quaternary age of the Yellowstone plateau underlie some 2,000 square miles in Yellowstone National Park (Boyd, 1961) and extend into adjacent parts of Montana and Idaho. They tend to occur as voluminous ash-flow sheets associated with calderas and lava flows (R. L. Christiansen and H. R. Blank, Jr., in U.S. Geological Survey, 1969, p. A37). Hamilton (1959, 1963) noted that these rhyolites, in terms of major element chemistry, are restricted to a very narrow range and, in general, are distinctly more alkalic than those of the orogenic basalt-andesite-rhyolite associations.

Gold content of randomly collected rhyolites (tuffs and flows) from the Yellowstone plateau is characteristically low; it ranges from $0.1 \mathrm{ppb}$ to $1.3 \mathrm{ppb}$ and averages $0.5 \mathrm{ppb}$ (table 38 ). The three samples of basalt, whose abundance is greatly subordinate to rhyolite in the region, have a relatively low gold content $(0.2 \mathrm{ppb}$, table 38$)$ and, in this respect, are similar to those of the Snake River Plain (table 6), even though the Snake River basalts are more alkalic (Hamilton, 1965).

\section{PRECAMBRIAN METAVOLCANIC ROCKS, CENTRAL ARIZONA}

Dacites, rhyolites, and quartz porphyries composing about one-third of the Yavapai Series (Precambrian) have been metamorphosed to the greenschist facies and then subsequently hydrothermally altered (Anderson, 1968). Analysis of 20 samples of these rocks, for which chemical, petrographic, and geologic data have been given by Anderson (1968), indicate gold content of rhyolites in the Ash Creek Group tends to be more variable (0.4-12.4 ppb) and higher (averaging $5.4 \mathrm{ppb}$ ) than in most rhyolites of the Alder Group (table 7). On the whole, the Alder rocks are less altered than the Ash Creek rocks and, with the exception of two strongly altered samples (nos. 18 and 19, table 39), have a gold content (0.2-0.9 ppb) typical of unaltered rhyolites from other provinces of the Western United States (table 7 and fig. 8). Similarly, the quartz porphyry tends to be more altered and have a relatively higher gold abundance (0.5-7.4 ppb) than samples of the Alder Group.

Differences in gold content of the samples analyzed can be related to chemical variations of major elements arising from alteration effects. This aspect is treated in more detail in connection with primary gold abundance and its bearing on gold mineralization (p. 28).

\section{BEATTY AREA, NEVADA}

Rhyolitic ash flows, tuffs, and lavas near Beatty, Nye County, Nev., are divided into two sequences: an older suite of probable Miocene age and a younger suite of probable Pliocene age (Cornwall, 1962). Ash flows of the older and younger suites are compositionally similar and believed to have been derived from two calderas, the Bullfrog Hills and Yucca Mountains calderas, respectively; volumetrically smaller flows of latite, rhyodacite, and basalt are associated with both calderas. Very few, if any, of the rhyolitic rocks are entirely unaltered, and some are locally intensely altered. Data on major and minor elements and geologic setting of the samples we analyzed for gold are given by Cornwall (1962) and Cornwall and Kleinhampl (1964).

The largest concentration of gold $(2.0-22 \mathrm{ppb})$ is in highly altered samples of the Bullfrog Hills caldera; the values of the less altered rhyolites are lower in gold and range from 0.2 to $0.9 \mathrm{ppb}$ (table $40)$. However, altered rhyolites of the Yucca Mountains caldera suite are only slightly enriched in gold (0.3-3.9 ppb), as compared with values typically observed for fresh rhyolite, that is, less than $1 \mathrm{ppb}$ (table 7). Two samples of basalt from the Beatty area, which have somewhat alkalic tendencies, contain 1.7 and $1.8 \mathrm{ppb}$ gold.

\section{CHALLIS VOLCANICS, CENTRAL IDAHO}

Recent studies by B. F. Leonard (in U.S. Geological Survey, 1968, p. A27) suggest that, even within a small area (Thunder Mountain caldera), the age of the Challis Volcanics can vary from Eocene to latest Oligocene or earliest Miocene, the same time span (Eocene? to Miocene?) generally accepted for the Challis on a regional scale. Limited sampling and analysis (table 41) indicate that rhyolite, dacite, latite, and andesite of the Challis Volcanics have a relatively low gold content (0.3-1.7 $\mathrm{ppb}$ ) that is typical of unaltered felsic and intermediate volcanic rocks of the Western United States (table 7 and fig. 8).

\section{SOUTHERN APPALACHIANS, VIRGINIA AND NORTH CAROLINA}

Lower Paleozoic calc-alkalic volcanic rocks, which range in composition from basalt to rhyolite and underlie a large part of the Carolina slate belt, have 
been metamorphosed to the lower greenschist facies (Butler and Ragland, 1969; Stromquist and Sundelius, 1969). Gold deposits in various parts of the southern Piedmont are spatially associated with felsic volcanic rocks (Pardee and Park, 1948), and recent studies by Bell (1969) indicate that the mineralization is related to early Paleozoic volcanism. Gold content of some samples from the area mapped by Stromquist (1966) in North Carolina is less than $1 \mathrm{ppb}$ except for one sample of andesite (table 42). These volcanic rocks have a gold con- tent much like that of plutonic rocks from the same general region (table 25).

Rhyolitic rocks of the Mount Rogers Formation are part of the Blue Ridge belt of the southern Appalachians. Uranium-lead isotopic ages on zircons from a few of these rhyolites indicate they are of late Precambrian age (Rankin and others, 1969). Gold abundance of petrographically diverse rhyolites from the Mount Rogers Formation, the geologic setting of which was given by Rankin (1970), is $0.5 \mathrm{ppb}$ or less, except for one sample (table 42 ).
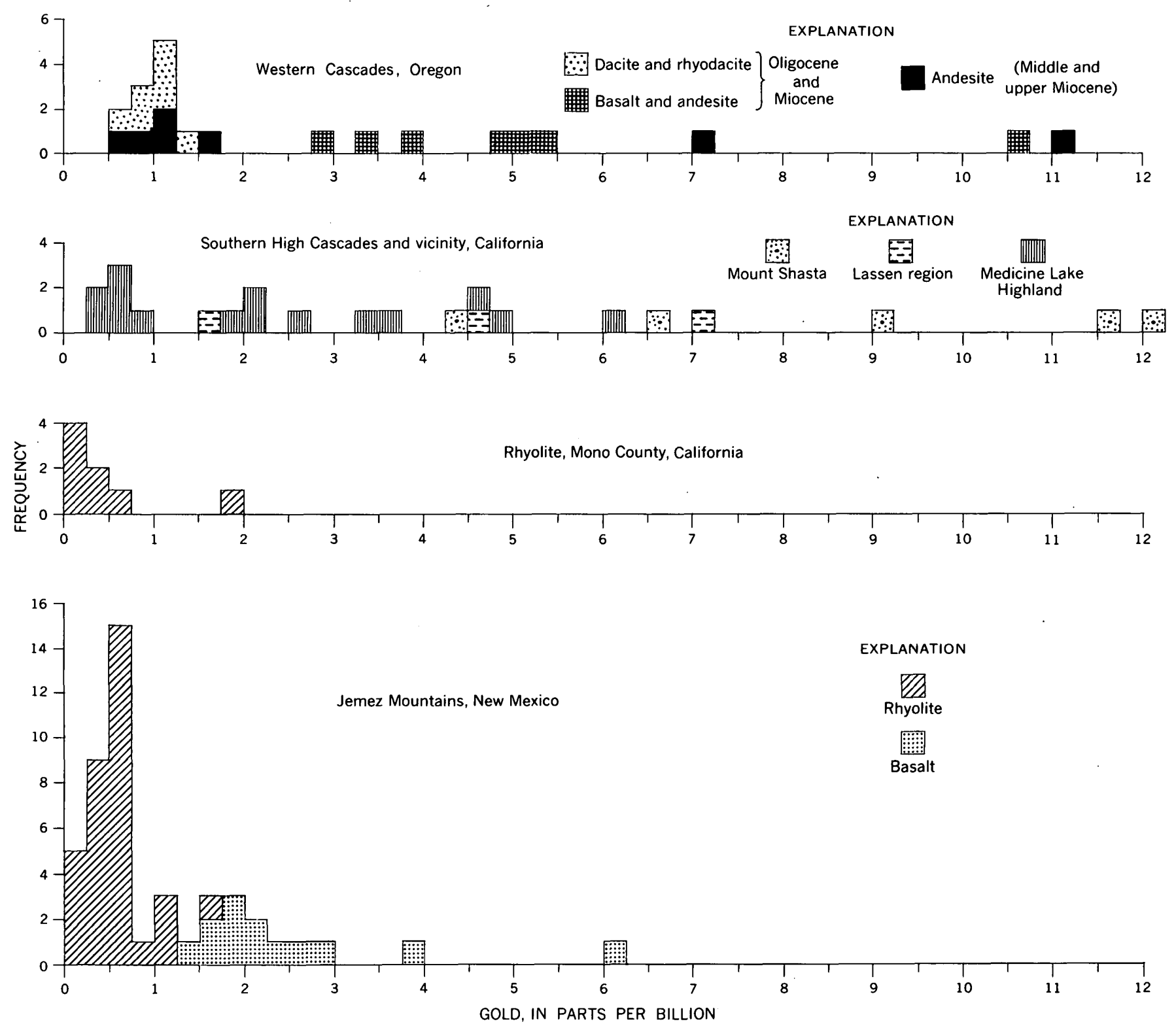

Figure 8.-Histograms of gold content of rocks from some calc-alkalic and basalt-andesite-rhyolite associations. The histogram for the southern High Cascades, Calif., does not show two samples from the Lassen region which have 14.1 and $19.4 \mathrm{ppb}$ gold. Data from tables 34-42. 
The gold content (table 42) in these Paleozoic and Precambrian felsic volcanic rocks from the southern Appalachians supports our previous generalization (Gottfried and others, 1969), based on fewer data, that the gold content of unaltered rhyolitic rocks, regardless of differences in composition, age, or provenance, is characterized by a very narrow and low range.

\section{ALKALIC PROVINCES}

BIG BEND NATIONAL PARK, TEX.

Igneous rocks from the Big Bend National Park area, which range from alkalic basalt to extremely $\mathrm{CaO}$-poor riebeckite rhyolite and granite, represent one of several alkalic subprovinces extending from Montana to Texas along the front of the Rocky Mountains. The Big Bend suite consists of highly alkaline extrusive and hypabyssal rocks, and sodium is slightly dominant relative to potassium. The petrology and geologic setting of these rocks have been given in abstracts by Lonsdale and Maxwell (1949) and Maxwell and Lonsdale (1949); partial chemical data on the rocks we analyzed for gold have been published elsewhere (Gottfried and others, 1962).

Despite the wide diversity of petrographic types, the ranges and averages of gold content are very nearly the same (table 43 and fig. 9) for all rocks
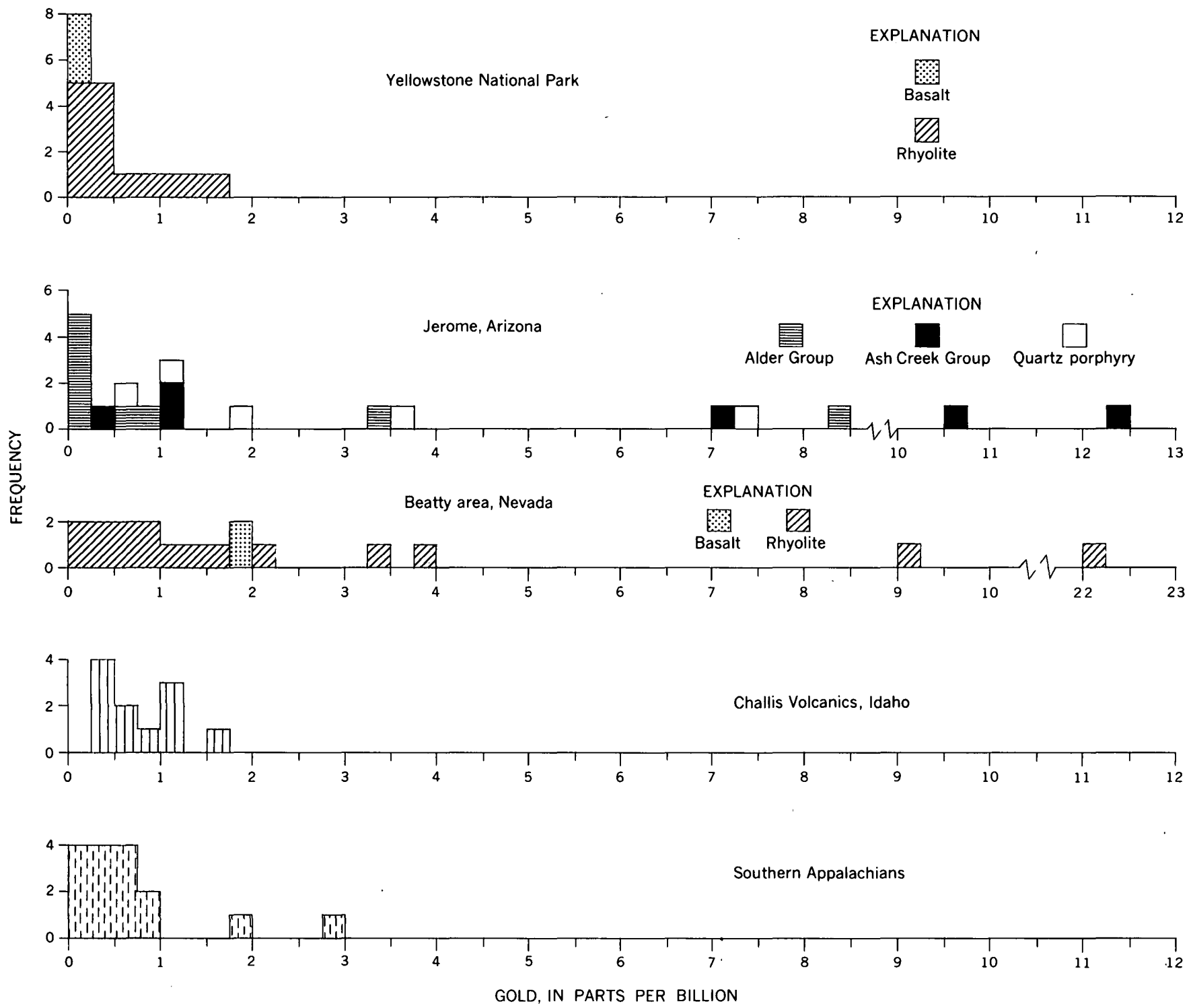

Figure 8.-Continued 


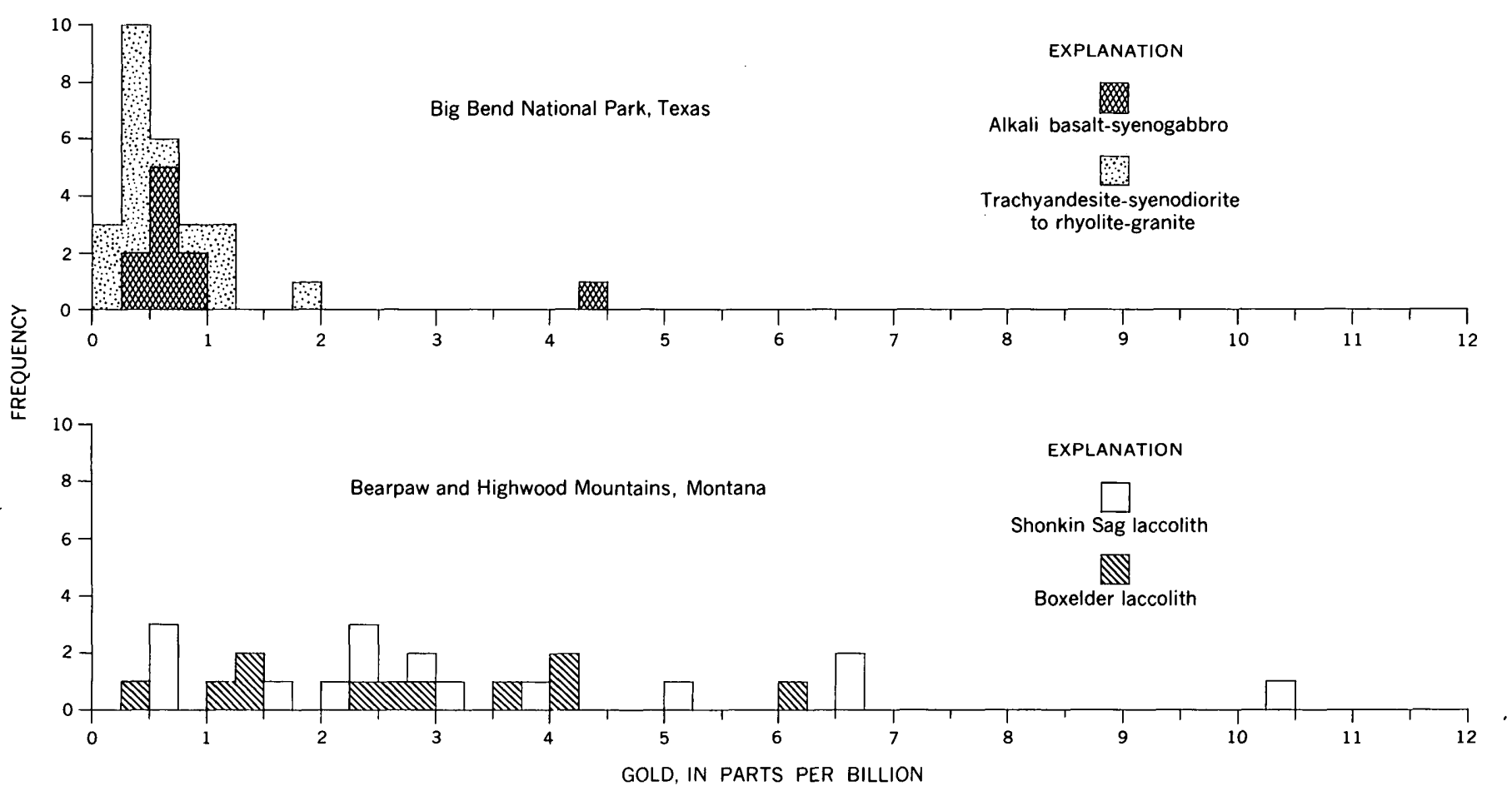

FIGURE 9.-Histograms of gold content of rocks from some alkalic provinces. Data from tables 43 and 44.

in the park. Except for three out of 27 samples, the rocks contain $1 \mathrm{ppb}$ or less gold and hence are similar in gold abundance to corresponding rock types of the moderately alkalic White Mountain Plutonic Series (table 24).

\section{BOXELDER AND SHONKIN SAG LACCOLITHS, MONTANA}

The differentiated Boxelder and Shonkin Sag laccoliths in the Bearpaw and Highwood Mountains, respectively, contain nearly the entire range of rock types found in the subsilicic-alkalic subprovince of central Montana described by Larsen (1940). The Boxelder laccolith (Pecora, 1941) is larger and grossly similar to the Shonkin Sag laccolith (Hurlbut, 1939), except that in the Boxelder the shonkinite and syenite contain plagioclase. Most of the rocks in both these bodies represent in place differentiation of shonkinitic magma to yield syenitic rocks. Chemically, these rocks are unusually high in $\mathrm{K}_{2} \mathrm{O}$ (4-9 percent) for rocks low in $\mathrm{SiO}_{2}$ (45-50 percent) and rich in $\mathrm{CaO}$ (2-11 percent).

Analyses for gold (table 44 and fig. 9) show that nearly all the shonkinitic rocks of both laccoliths are distinctly higher in gold than are the alkalic basalts from other petrographic provinces (compare tables 44 and 7 ). In the Boxelder laccolith, gold content decreases systematically from an average of $3.5 \mathrm{ppb}$ for the shonkinitic rocks to $1.4 \mathrm{ppb}$ for the late aplitic and pegmatitic phases (table 44), an indication of progressive depletion of gold in the magma as differentiation proceeded. In contrast, gold variation in the Shonkin Sag laccolith is more irregular. The basal mafic phonolite, which should represent the initial gold content of the magma, has a higher gold content (10.4 ppb) than any rock in the laccolith. Replicate analyses on this sample rule out the possibility that this anomalously high value stems from analytical error. Another mafic phonolite is unusually low in gold $(1.6 \mathrm{ppb})$. Hurlbut (1939) noted the presence of carbonate and zeolites in these mafic phonolites as well as in some other rocks of the laccolith, and it is possible that these rather extreme variations in gold content may to some extent reflect postcrystallization alteration processes.

\section{SUMMARY DISCUSSION OF GOLD IN VOLCANIC ASSOCIATIONS}

From the preceding discussions of gold in volcanic series from region to region (tables 26-44 and figs. 4-9), several. important generalizations emerge and are summarized briefly below:

1. Excluding all samples known, or suspected, to have undergone postmagmatic alteration, grand averages, calculated from group aver- 
ages for some 400 samples from diverse regions show the general tendency for mafic volcanic rocks to be higher in gold than felsic varieties (table 8 ). This tendency is also noted for the plutonic rocks we analyzed (see table $5)$. Our summary of mean gold abundances for volcanic rocks is in general accord with summaries of previous workers (for example, Phan, 1965; Shcherbakov and Perezhogin, 1964), there being one notable exception. The summary by Jones (1969, table 5), based on scanty data, gives the average gold content for rhyolite as $12 \mathrm{ppb}$, which is larger than our value of $0.7 \mathrm{ppb}$ by almost a factor of 20 . We believe that the apparent relationship noted by Jones (1969) - gold content is inversely proportional to rock basicity in volcanic rocks but directly proportional in plutonic rocks-is not supported by the vastly increased volume of data now available and probably is a result of "selective sampling," as he had suggested.

TABLE 8.-Average gold content in selected rocks representative of different volcanic associations

[Based on data from tables 6 and 7]

\begin{tabular}{|c|c|c|}
\hline Rock type & $\begin{array}{l}\text { Number of } \\
\text { samples }\end{array}$ & $\begin{array}{c}\text { Average } \\
\text { gold } \\
\text { content } \\
\text { (ppb) }\end{array}$ \\
\hline \multicolumn{3}{|l|}{ Basalt: } \\
\hline $\begin{array}{l}\text { Hawaiian tholeiite } \\
\text { Oceanic tholeiite }\end{array}$ & 26 & 2.3 \\
\hline $\begin{array}{l}\text { Continental tholeiite } \\
\text { Conte }\end{array}$ & $\begin{array}{r}42 \\
149\end{array}$ & 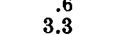 \\
\hline Circumpacific basalt & 21 & 5.4 \\
\hline \multirow{2}{*}{\multicolumn{3}{|c|}{ Andesite: }} \\
\hline & & \\
\hline Alkalic associations & $\begin{array}{r}21 \\
5\end{array}$ & $\begin{array}{l}4.6 \\
1.5\end{array}$ \\
\hline Dacite to rhyodacite & $\begin{array}{c}5 \\
9\end{array}$ & $\begin{array}{l}1.0 \\
.8\end{array}$ \\
\hline Quartz latite to rhyolite & 77 & .7 \\
\hline Trachyandesite to trachyte & 10 & .6 \\
\hline Shonkinite-phonolite to syenite & & \\
\hline
\end{tabular}

2. For those undifferentiated samples generally believed to represent parent magmas, the data indicate a strikingly limited range of gold content, even though a nearly complete spectrum of basaltic magma types in diverse geologic settings is represented. When the samples that show evidence of alteration are omitted, this range is from about 0.5 to $5.0 \mathrm{ppb}$ gold, that is, a factor of only 10 . However, within this range, differences in gold content on a provincial or regional scale are discernible and can sometimes be related to bulk chemical composition and perhaps tectonic setting. While gold content tends to decrease in abundance from tholeiitic to alkalic basalts in the Hawaiian province, it is significantly lower in the low- $\mathrm{K}_{2} \mathrm{O}$ tholeiitic basalts of the ridge-and-rise system than in the chemically equivalent (except for $\mathrm{TiO}_{2}$ ) diabase dikes in the Triassic basin in the Piedmont of North Carolina. The recent study of MacGregor (1969) suggested that the geographic distinction between oceanic island basalts and circumoceanic basalts more likely reflects "tectonic setting" than "regional geochemical variations." That the oceanic tholeiites and alkalic basalts, which represent the opposite extremes in terms of abundance of lithophilic major and trace elements, have virtually the same gold content also clearly indicates that chemical data on major elements alone provide no universal guides in predicting gold content.

3. In differentiated diabase-granophyre sheets from regions devoid of mineralization and alteration, gold either is distributed uniformly over the range of rock types analyzed (for example, the suite from Virginia, table 31) or increases to a maximum in rocks representing the intermediate stages of differentiation (for example, the Great Lake sheet, Tasmania, table 33). The first pattern is similar to that for the Skaergaard intrusion in east Greenland (Vincent and Crocket, 1960a) ; the second, to that for the Anakita intrusion in the Siberian platform (Shcherbakov and Perezhogin, 1964). Thus, in none of the differentiated suites studied to date is there any evidence that gold becomes highly concentrated in the final products of magmatic crystallization.

4. Gold shows chalcophilic tendencies. Data for a single suite from the Great Lake intrusion unequivocably demonstrate this tendency ( $p$. 14), which is also expressed by the gross positive correlation between gold and copper content in extrusive and hypabyssal rocks of several petrochemically distinct suites taken collectively (fig. 10). The greater scatter of gold and copper content observed for the Dillsburg intrusion and the Greenstone Flow is due to alteration effects (p. 11, 12). Moreover, the general tendency for gold abundance to decrease from tholeiite to alkalic basalt in the Hawaiian province is matched by a decrease in copper content (data of Herliska in Macdonald, 1969) in corresponding rocks in the Hawaiian province. Finally, in the Apollo 11 lunar basalts, the surprisingly low gold content, averaging $0.04 \mathrm{ppb}$, is accompanied by low copper content, averaging $7.5 \mathrm{ppm}$ (Keays and others, 1970). 


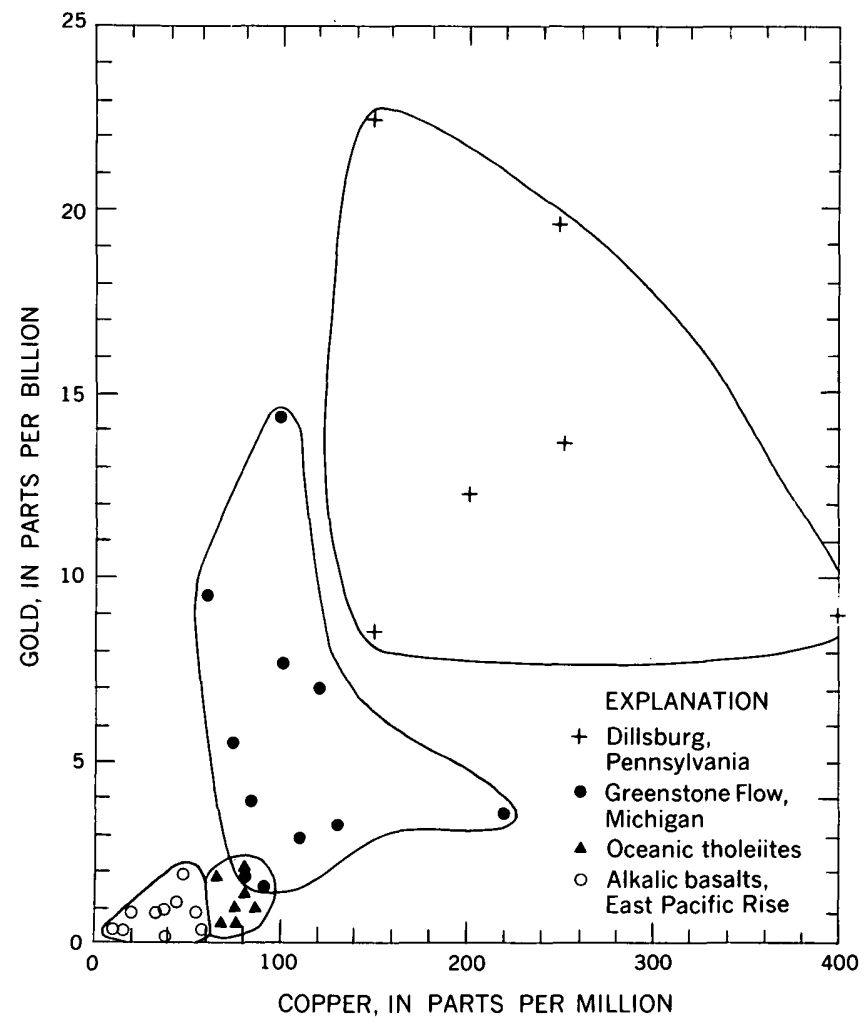

Figure 10.-Variation of gold abundance with copper abundance in samples from four basaltic suites. Data from tables 27,30 , and 31 .

5. The highest gold content generally occurs in the basaltic and andesitic members of the calcalkalic associations of the circumpacific (orogenic) belt; this association occurs along the margin of the Western United States as well as in the continental interior (Rocky Mountain province). The mafic rocks of the orogenic belts tend to be somewhat higher in gold content than those of the more stable cratonic regions or the primitive basalts of the $\mathrm{Ha}$ waiian Islands (table 7). Rhyolitic rocks of calc-alkalic series as well as those of alkalic affinities are uniformly low in gold, regardless of geologic setting. Our data, however, do not preclude the possible existence of regional or provincial variations in gold content in the rhyolites because the overall uncertainty of the analytical determinations (p. 3) may mask statistically significant differences in the concentration range of 0.1-1.0 ppb.

6. In alkalic provinces all rock types, regardless of composition, are low in gold. An example of such rocks, characterized by a low-CaO and relatively high sodium content, is the suite from the Big Bend area (table 43 and p. 19).
However, the subsilicic-alkalic rocks from central Montana (table 44), characterized by unusually high potassium but also high $\mathrm{CaO}$ content, have a distinctly higher gold content than low-CaO alkalic rocks. Moreover, the progressive decrease in gold content from mafic shonkinite to late syenitic differentiates in samples from the Boxelder laccolith, Bearpaw Mountains, Mont., suggests that gold decreases with magmatic differentiation, a fact observed for many of the plutonic suites we studied (p. 6).

\section{MODE OF OCCURRENCE OF GOLD IN IGNEOUS ROCKS}

Gold-abundance data on igneous rocks suggest at least the gross correlation that the more mafic the rock, the more likely it is to have a relatively higher gold content. This, of course, implies some sort of mineralogic (hence, chemical) control and raises the question: How is gold distributed in a rock or, for that matter, in its constituent minerals? Unfortunately, only few quantitative data can be marshaled to attempt to answer this question and others related to the mode of occurrence of gold in unaltered igneous rocks (at the parts-per-billion level). Reliable determinations of gold in minerals common in igneous rocks are few indeed and have been summarized by Phan (1965) and more recently by Jones and Fleischer (1969). Most of the published values of gold in minerals relate to samples outside the United States; only the data of Mantei and Brownlow (1967) and, to a much lesser extent, of Vincent and Crocket $(1960 \mathrm{~b})$ pertain to samples within the United States.

To interpret our rock data better and in hopes of gaining some insight into the distribution of gold in rocks, we selected several rocks representative of several batholiths for detailed study. The principal minerals from these rocks were separated by a combination of heavy-liquid and magnetic techniques and analyzed for gold. All mineral separates examined optically and (or) by X-ray are estimated to be 98 percent or better in purity.

\section{ABUNDANCE LEVEL IN MINERALS}

Gold content of the minerals we analyzed (tables 9-13) appears to be lower than published values by Phan (1965) and Jones (1969) for comparable mineral groups. The apparent levels are even more striking if we compare our results with those of Mantei and Brownlow (1967), who studied samples from the Marysville stocks; this igneous body is a satellitic pluton of the Boulder batholith, Mon- 
tana, and the host rock for several important gold mines (Barrell, 1907; Knopf, 1913, 1950). The reasons for the apparent gross differences between our data and available published data are not known, but certainly the possibilities of analytical error and variations in sample purity must be considered. Nonetheless, despite these differences in absolute concentration levels, our data on minerals exhibit the general relative relationship noted by previous workers: sulfides tend to be highest in gold whereas mafic silicates and iron and titanium oxides tend to be relatively higher in gold than are such salic minerals as feldspar and quartz. These observations, together with the positive correlation of gold abundance and abundance of mafic minerals in a rock, led us to suggest previously (Gottfried and others, 1969) that gold becomes depleted in the residual melt as magmatic differentiation proceeds. This generalization appears to be valid for most calc-alkalic suites but not necessarily for suites of other petrochemical affinities.

\section{DISTRIBUTION OF GOLD BETWEEN MINERALS IN A ROCK}

In order to assess the contribution of each principal mineral to the overall gold budget and at the same time check the analytical consistency of rock and mineral data, we calculated material balances for several samples (tables 9-13). Several features of these calculations are noteworthy:

1. The agreement between total gold in a rock by the sum of minerals and that actually measured is fairly good, considering the analytical and sampling uncertainties discussed earlier (p. 3). For plutonic rocks we consider the agreement to be acceptable if the measured and summed values are within a factor of two. Furthermore, these calculations suggest an internally consistent data set and the lack of systematic bias in the precision of the determinations.

2. Although the mafic minerals, on the average, tend to be higher in gold than the salic minerals, in many of the samples the salic minerals contribute as much or more gold to the total rock values than do the mafic minerals. This is shown particularly well by highly felsic rocks (for example, sample $62 \mathrm{~K}-00$, table 10 , and sample El 38-167, table 9), in which the quartz-plus-feldspar fraction contributes more than 90 percent of the measured rock gold.

3. Except for sample $6 \mathrm{~K}-306$ in table 10 , the calculations show that either the material bal- ances are in virtual agreement (by factor of two) or the total gold by the sum of minerals is lower than gold measured directly in rock; in some samples, (BP-1 and Mo-1c, table 11) the total gold is considerably lower. Low-total gold by sum of minerals may be the result of any (or a combination) of the following factors:

(a) Not all the material that contributes to the total rock gold has been considered in the material-balance computations. Inasmuch as the mineral separates we analyzed were prepared from crushed rock coarser than 200 mesh, a strong possibility exists that the fraction of the rock finer than 200-mesh may contain a finite amount of gold, be it associated with some minor mineral phase or even present in the native state.

(b) The final mineral separates analyzed may be "over-purified" for materialbalance calculations for gold. Most of the mineral separates were prepared originally in connection with other petrologic and geochemical studies, which required that separates be free of inclusions (generally oxides and sulfides). However, the "impure" (inclusion-rich) mineral fractions that were not analyzed might have contributed significantly to the total gold budget.

(c) Systematic analytical bias may exist between rock and mineral values. This possibility, though it is not in the least suggested by the data and we feel it is probably remote, nonetheless cannot be dismissed entirely.

Because we wanted another test of material balance and, at the same time, wanted to minimize the possible effects of the previously listed factors, we analyzed four samples of the Butte Quartz Monzonite from underground workings (table 13). These samples are hydrothermally altered to varying degrees. Sample 733 is the least altered and shows only a small degree of sericitization of feldspar, slight alteration of mafic silicates, and trace amounts of pyrite and other sulfides; sample 731 is the most altered and contains the greatest amounts of sulfides. To minimize possible bias related to sample preparation, the samples were disaggregated, but not sized, and separated into three density fractions by heavy-liquid separation techniques. The data on 
TABLE 9.-Distribution of gold in minerals of some rocks from the Southern California batholith

[Abundance: Calculated from volume-percent mode assuming appropriate density for constituent mineral. Gold in rock, by mineral: Abundance of mineral, expressed in weight percent divided by 100, multiplied by amount of gold in mineral (ppb). ND, no data]

\begin{tabular}{|c|c|c|c|c|c|c|c|c|c|}
\hline \multirow[b]{3}{*}{ Mineral } & \multirow{2}{*}{\multicolumn{3}{|c|}{ El 38-167 Quartz monzonite }} & \multicolumn{6}{|c|}{ Tonalite } \\
\hline & & & & \multicolumn{3}{|c|}{$60-2$} & \multicolumn{3}{|c|}{66 GSC-18 } \\
\hline & $\begin{array}{c}\text { Abundance } \\
\text { (weight } \\
\text { percent) }\end{array}$ & $\begin{array}{c}\text { Gold } \\
(\mathrm{ppb})\end{array}$ & $\begin{array}{l}\text { Gold in } \\
\text { rock, by } \\
\text { mineral } \\
(\text { ppb })\end{array}$ & $\begin{array}{c}\text { Abundance } \\
\text { (weight } \\
\text { percent) }\end{array}$ & $\begin{array}{r}\text { Gold } \\
\text { (ppb) }\end{array}$ & $\begin{array}{l}\text { Gold in } \\
\text { rock, by } \\
\text { mineral } \\
(\text { ppb })\end{array}$ & $\begin{array}{c}\text { Abundance } \\
\text { (weight } \\
\text { percent) }\end{array}$ & $\begin{array}{c}\text { Gold } \\
(\mathrm{ppb})\end{array}$ & $\begin{array}{l}\text { Gold in } \\
\text { rock, by } \\
\text { mineral } \\
(\mathrm{ppb})\end{array}$ \\
\hline \multirow{7}{*}{ 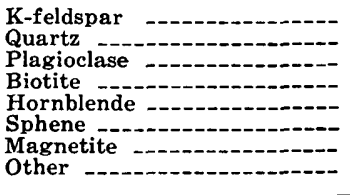 } & 32.0 & $1.0^{\circ}$ & 0.32 & $-0-$ & & $-\pi$ & & $-\pi$ & --- \\
\hline & 32.0 & .6 & $.20\}$ & $\overline{770}$ & $\overline{2}$ & $\overline{0.15}$ & $\overline{777}$ & 0.3 & $\overline{0.23}$ \\
\hline & 33.0 & 3.4 & $1.12\}$ & 77.0 & 0.2 & 0.15 & 77.7 & 0.3 & 0.23 \\
\hline & 2.0 & 5.3 & .11 & 13.0 & 1.2 & .16 & 5.3 & .1 & $\begin{array}{l}.00 \\
.03\end{array}$ \\
\hline & $\begin{array}{r}1.0 \\
-\end{array}$ & & .00 & $\begin{array}{r}7.0 \\
----\end{array}$ & $\begin{array}{l}1.3 \\
---\end{array}$ & $\begin{array}{r}.09 \\
----\end{array}$ & $\begin{array}{r}16.4 \\
.2\end{array}$ & .2 & $\begin{array}{l}.03 \\
.00\end{array}$ \\
\hline & .5 & 49.3 & .25 & & & & & & \\
\hline & $-\cdots$ & $\cdots$ & ---- & 3.0 & ND & ---- & .4 & ND & --- \\
\hline \multirow{3}{*}{$\begin{array}{l}\text { Total gold (by sum of } \\
\text { minerals) } \\
\text { Total gold in bulk rock } \\
\text { (measured) }\end{array}$} & --.-- & ---. & 2.0 & -.-- & --- & .4 & ---- & --- & .3 \\
\hline & 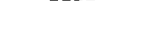 & & - & & & 25 & & & 7 \\
\hline & --- & --- & 1.9 & --- & -- & 2.6 & $\cdots$ & -- & .7 \\
\hline
\end{tabular}

TABLE 10.-Distribution of gold in minerals of some rocks from the Boulder batholith, Montana

[Abundance: Calculated from volume-percent mode assuming appropriate density for constituent mineral. Gold in rock, by mineral: Abundance of mineral, expressed in weight percent divided by 100, multiplied by amount of gold in mineral (ppb). ND, no data; Tr., trace]

\begin{tabular}{|c|c|c|c|c|c|c|c|c|c|}
\hline \multirow[b]{2}{*}{ Mineral } & \multicolumn{3}{|c|}{ Alaskite $62 \mathrm{~K}-00$} & \multicolumn{3}{|c|}{ Quartz monzonite $6 \mathrm{~K}-306$} & \multicolumn{3}{|c|}{ Granodiorite $2 \mathrm{~T}-1065$} \\
\hline & $\begin{array}{c}\text { Abundance } \\
\text { (weight } \\
\text { percent) }\end{array}$ & $\begin{array}{l}\text { Gold } \\
(\mathrm{ppb})\end{array}$ & $\begin{array}{l}\text { Gold in } \\
\text { rock, by } \\
\text { mineral } \\
(\text { ppb })\end{array}$ & $\begin{array}{c}\text { Abundance } \\
\text { (weight } \\
\text { percent) }\end{array}$ & $\underset{\text { (pold }}{\text { Gpb) }}$ & $\begin{array}{l}\text { Gold in } \\
\text { rock, by } \\
\text { mineral } \\
(\text { ppb })\end{array}$ & $\begin{array}{c}\text { Abundance } \\
\text { (weight } \\
\text { percent) }\end{array}$ & $\begin{array}{l}\text { Gold } \\
\text { (ppb) }\end{array}$ & $\begin{array}{l}\text { Gold in } \\
\text { rock, by } \\
\text { mineral } \\
(\mathrm{ppb})\end{array}$ \\
\hline $\begin{array}{l}\text { K-feldspar } \\
\text { Quartz and plagioclase } \\
\text { Biotite } \\
\text { Hornblende } \\
\text { Magnetite } \\
\text { Sphene } \\
\text { Other }\end{array}$ & $\begin{array}{r}42.6 \\
53.4 \\
1.7 \\
-1.0 \\
1.3\end{array}$ & $\begin{array}{r}1.4 \\
.2 \\
2.2 \\
13.5 \\
\mathrm{ND}\end{array}$ & $\begin{array}{r}0.60 \\
.11 \\
.04 \\
-.-\overline{1} \\
.14 \\
----\end{array}$ & $\begin{array}{r}21.2 \\
60.9 \\
8.5 \\
5.8 \\
1.9 \\
.3 \\
\mathrm{Tr} .\end{array}$ & $\begin{array}{r}0.1 \\
.3 \\
15.8 \\
1.2 \\
8.6 \\
34.6 \\
----\end{array}$ & $\begin{array}{r}0.02 \\
.18 \\
1.34 \\
.01 \\
.16 \\
.10 \\
-.--\end{array}$ & $\begin{array}{r}17.0 \\
67.8 \\
5.3 \\
6.7 \\
2.7 \\
-.5\end{array}$ & $\begin{array}{r}0.5 \\
.2 \\
.8 \\
.9 \\
5.1 \\
\mathrm{ND}\end{array}$ & $\begin{array}{r}0.09 \\
.14 \\
.04 \\
.06 \\
.14 \\
-.--\end{array}$ \\
\hline $\begin{array}{l}\text { Total gold (by sum of } \\
\text { minerals) } \\
\text { Total gold in bulk rock } \\
\text { (measured) }\end{array}$ & --- & --- & $\begin{array}{l}.9 \\
.7\end{array}$ & --- & --- & $\begin{array}{r}1.8 \\
.8\end{array}$ & $--\infty$ & --- & 1.0 \\
\hline
\end{tabular}

1 Another determination on the hornblende gave a spurious value of $131.7 \mathrm{ppb}$.

TABLE 11.-Distribution of gold in minerals of some rocks from the Sierra Nevada batholith and Coast Range plutons, California [Abundance: Calculated from volume-percent mode assuming appropriate density for constituent mineral. Gold in rock, by mineral: Abundance of mineral, expressed in weight percent divided by 100, multiplied by amount of gold in mineral (ppb). ND, no data; Tr., trace]

\begin{tabular}{|c|c|c|c|c|c|c|c|c|c|c|c|c|c|c|c|c|c|c|}
\hline \multirow[b]{3}{*}{ Mineral } & \multicolumn{12}{|c|}{ Sierra Nevada batholith } & \multicolumn{6}{|c|}{ Coast Range plutons } \\
\hline & \multicolumn{3}{|c|}{ MG-1 } & \multicolumn{3}{|c|}{ CL -1} & \multicolumn{3}{|c|}{ SL-18 } & \multicolumn{3}{|c|}{ BP-1 } & \multicolumn{3}{|c|}{ Dr-510 } & \multicolumn{3}{|c|}{ Mo-1c } \\
\hline & 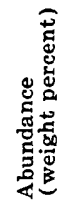 & $\begin{array}{l}0 \\
0 \\
0 \\
0 \\
0 \\
0\end{array}$ & 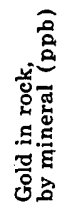 & 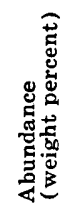 & 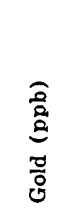 & 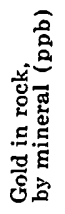 & 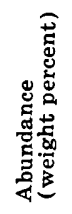 & 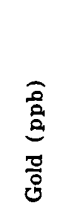 & 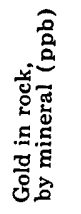 & 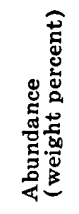 & 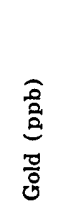 & 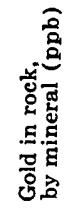 & 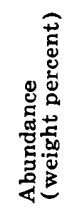 & 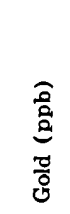 & 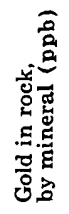 & 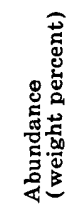 & 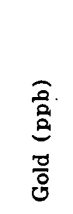 & 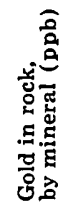 \\
\hline \multirow{3}{*}{$\begin{array}{l}\text { K.-feldspar } \\
\text { Quartz and plagio- } \\
\text { clase } \\
\text { Biotite } \\
\text { Hornblende- } \\
\text { Hypersthene - } \\
\text { Magnetite - } \\
\text { Other }\end{array}$} & 16.8 & 0.1 & 0.02 & --- & --- & --- & 13.1 & 0.1 & 0.01 & 15.9 & 0.2 & 0.03 & Tr. & ND & --- & 18 & .02 & 0.04 \\
\hline & $\begin{array}{r}63.2 \\
9.2 \\
8.8\end{array}$ & $\begin{array}{l}.1 \\
.8 \\
.4\end{array}$ & $\begin{array}{l}.06 \\
.07 \\
.04\end{array}$ & $\begin{array}{r}62.8 \\
3.3 \\
21.3\end{array}$ & $\begin{array}{r}0.1 \\
\text { ND } \\
.3\end{array}$ & $\begin{array}{r}0.06 \\
\hdashline .06\end{array}$ & $\begin{array}{r}66.3 \\
13.7 \\
5.3\end{array}$ & $\begin{array}{l}.1 \\
.6 \\
.4\end{array}$ & $\begin{array}{l}.07 \\
.08 \\
.02\end{array}$ & $\begin{array}{r}64.2 \\
4.9 \\
10.7\end{array}$ & $\begin{array}{r}.2 \\
.5 \\
1.2\end{array}$ & $\begin{array}{l}.13 \\
.02 \\
.13\end{array}$ & $\begin{array}{l}69 \\
15 \\
16\end{array}$ & $\begin{array}{r}0.1 \\
.9 \\
.5\end{array}$ & $\begin{array}{r}0.07 \\
.14 \\
.08\end{array}$ & $\begin{array}{r}76 \\
6 \\
---\end{array}$ & $\begin{array}{r}.1 \\
.4 \\
-.-\end{array}$ & $\begin{array}{r}.08 \\
.02 \\
-\end{array}$ \\
\hline & $\begin{array}{r}-1.3 \\
.7\end{array}$ & $\begin{array}{r}-4 \\
-.4 \\
\text { N }\end{array}$ & .005 & $\begin{array}{r}10.0 \\
2.6 \\
\end{array}$ & $\begin{array}{r}.3 \\
\text { ND } \\
---\end{array}$ & \begin{tabular}{c}
.03 \\
\hdashline-0. \\
$-\cdots$
\end{tabular} & $\begin{array}{r}.4 \\
1.2\end{array}$ & 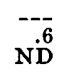 & .002 & $\begin{array}{l}2.6 \\
1.7\end{array}$ & $\begin{array}{r}-\overline{.5} \\
\mathrm{ND}\end{array}$ & $-. \overline{01}\}$ & Tr. & ND & ---- & $\begin{array}{l}-- \\
\text { Tr. }\end{array}$ & $\overrightarrow{\mathrm{ND}}$ & ---- \\
\hline $\begin{array}{l}\text { Total gold (by } \\
\text { sum of min- } \\
\text { erals) } \\
\text { Total gold in }\end{array}$ & --- & --- & .2 & --- & --- & .2 & --- & -- & .2 & ---- & --- & .3 & --- & -- & .3 & --- & --- & .1 \\
\hline (measured) -- & -..- & --- & .5 & ---- & --- & 1.6 & --- & --- & .9 & ---- & --- & 6.0 & --- & --- & .8 & -- & --- & 6.0 \\
\hline
\end{tabular}


these fractions clearly indicate that the material balance is better than most observed for those samples sized for mineral separation (tables 9-12). Moreover, the sulfide-predominant fraction (specific gravity $>3.3$ is clearly the principal contributor of gold. It should be noted the balances are good over a wide range (1.5-65 ppb) of rock gold abundance. As might be expected, the sample for which the heaviest (sulfide-bearing) fraction was inadvertently lost shows the worst material balance.

TABLE 12.-Distribution of gold in minerals of a sample of the Silver Plume Granite (G-78), Silver Plume, Colo.

[Abundance: Calculated from volume-percent mode assuming appropriate density for constituent mineral. Gold in rock, by mineral: Abundance of mineral, expressed in weight percent divided by 100 , multiplied by amount of gold in mineral ( $p p b)$. ND, no data]

\begin{tabular}{|c|c|c|c|}
\hline Mineral & $\begin{array}{c}\text { Abundance } \\
\text { (weight } \\
\text { percent) }\end{array}$ & $\begin{array}{c}\text { Gold } \\
(\mathrm{ppb})\end{array}$ & $\begin{array}{c}\text { Gold in rock, } \\
\text { by mineral } \\
(\mathrm{ppb})\end{array}$ \\
\hline $\begin{array}{l}\text { Quartz and feldspar } \\
\text { Biotite } \\
\text { Muscovite } \\
\text { Magnetite } \\
\text { Pyrite } \\
\text { Other }\end{array}$ & $\begin{array}{r}83.0 \\
9.0 \\
5.0 \\
.5 \\
.1 \\
2.4\end{array}$ & $\begin{array}{r}0.3 \\
.3 \\
\mathrm{ND} \\
1.2 \\
70 \\
\mathrm{ND}\end{array}$ & $\begin{array}{r}0.25 \\
.03 \\
-.0 \overline{1} \\
.07 \\
----\end{array}$ \\
\hline $\begin{array}{l}\text { Total gold (by sum of } \\
\text { minerals) } \\
\text { Total gold in bulk rock } \\
\text { (measured) }\end{array}$ & $\cdots$ & $\cdots$ & .4 \\
\hline
\end{tabular}

In summary, our material balances indicate that, in most igneous rocks, even the very freshest, the gold measured in the rock tends to be greater than that indicated by the summation of gold contribution from the principal rock-forming minerals. This implies that some of the gold may reside elsewhere in the rock, possibly in phases volumetrically small but comparatively rich in gold (for example, sulfides) or even as intergranular native gold. To the best of our knowledge, the nature of the form or forms taken by gold in rocks and minerals is still unknown. Questions of the extent to which gold is isomorphously taken into mineral structures, the proportion of gold fixed in minerals (either isomorphously or simply as included material) to that in interstices of the rock, the amount and mode of transport of gold, and so on, are beyond the scope of the present study.

\section{BEARING OF PRIMARY GOLD ABUNDANCE ON GOLD MINERALIZATION}

Abundance data clearly establish the generally low concentration levels of gold in unaltered igneous rocks ("background levels") of widely differing composition and geologic setting. Of more direct economic importance, however, is the crucial question: how do these "background levels" of gold relate, if at all, to gold mineralization? Some previous investigators (for example, Mantei and Brownlow, 1967; Voskresenskaya and Zvereva, 1968) have linked gold mineralization to a high gold content in the magma forming the host rock. Such an association or its antithesis (that is, a low metal content in the host rock because of the mineralization) has commonly been invoked by economic geologists to account for the concentration of metals. This vexing problem and contradictory answers to it have been discussed and evaluated by Krauskopf (1967). As stated at the outset, it is not our purpose to treat any region of gold mineralization in detail; nonetheless, in order to support some generalizations and to show how our data bear on the relationship between primary gold abundance of host rock and gold mineralization, we shall make reference to a few selected examples.

\section{BOULDER BATHOLITH REGION, MONTANA}

The Butte Quartz Monzonite and related rocks, which form about 70 percent of the exposed Boulder batholith, contain nearly all the metallic deposits of any economic consequence in the region; comparatively, the other plutons of the batholith are virtually barren in terms of metallic mineralization.

TABLE 13.-Distributions of gold in different density fractions of some samples of Butte Quartz Monzonite from underground workings

[Rock samples provided by E. C. Robertson. U.S. Geol. Survey. Abundance: Calculated from volume-percent mode assuming appropriate density for constituent mineral. Gold in rock, by mineral: Abundance of mineral, expressed in weight percent divided by 100, multiplied by amount of gold in mineral $(\mathrm{ppb})]$

\begin{tabular}{|c|c|c|c|c|c|c|c|c|c|c|c|c|}
\hline \multirow[b]{2}{*}{$\begin{array}{l}\text { Density } \\
\text { fraction }\end{array}$} & \multicolumn{3}{|c|}{ Sample 731} & \multicolumn{3}{|c|}{ Sample 733} & \multicolumn{3}{|c|}{ Sample 725} & \multicolumn{3}{|c|}{ Sample 720} \\
\hline & $\begin{array}{c}\text { Abundance } \\
\text { (weight } \\
\text { percent) }\end{array}$ & $\begin{array}{c}\text { Gold } \\
(\mathrm{ppb})\end{array}$ & $\begin{array}{c}\text { Gold in } \\
\text { rock, by } \\
\text { mineral } \\
(\mathrm{ppb})\end{array}$ & $\begin{array}{c}\text { Abundance } \\
\text { (weight } \\
\text { percent) }\end{array}$ & $\begin{array}{c}\text { Gold } \\
(\mathrm{ppb})\end{array}$ & $\begin{array}{l}\text { Gold in } \\
\text { rock, by } \\
\text { mineral } \\
(p p b)\end{array}$ & $\begin{array}{c}\text { Abundance } \\
\text { (weight } \\
\text { percent) }\end{array}$ & $\begin{array}{l}\text { Gold } \\
(\mathrm{ppb})\end{array}$ & $\begin{array}{c}\text { Gold in } \\
\text { rock, by } \\
\text { mineral } \\
(p p b)\end{array}$ & $\begin{array}{c}\text { Abundance } \\
\text { (weight } \\
\text { percent) }\end{array}$ & $\begin{array}{c}\text { Gold } \\
(\mathrm{ppb})\end{array}$ & $\begin{array}{c}\text { Gold in } \\
\text { rock, by } \\
\text { mineral } \\
(p p b)\end{array}$ \\
\hline \multirow{3}{*}{$\begin{aligned} & \text { Sp gr }<2.8 \\
& \text { Sp } \text { gr }>2.8<3.3 \\
& \text { Sp gr }>3.3 \\
& \text { Total gold (by sum } \\
& \text { of fractions) }-\overline{-} \\
& \text { Total gold in bulk } \\
& \text { rock (measured) }\end{aligned}$} & $\begin{array}{r}85 \\
10 \\
5\end{array}$ & $\begin{array}{r}24 \\
113 \\
707\end{array}$ & $\begin{array}{l}20 \\
11 \\
35\end{array}$ & $\begin{array}{r}97.5 \\
1.3 \\
1.2\end{array}$ & $\begin{array}{c}0.7 \\
5.4 \\
22\end{array}$ & $\begin{array}{r}0.7 \\
.1 \\
.3\end{array}$ & $\begin{array}{r}86 \\
9 \\
5\end{array}$ & $\begin{array}{r}8.9 \\
63.0 \\
(1)\end{array}$ & $\begin{array}{c}7.6 \\
5.7 \\
---\end{array}$ & $\begin{array}{r}91.0 \\
6.7 \\
2.3\end{array}$ & $\begin{array}{r}16 \\
60 \\
152\end{array}$ & $\begin{array}{r}14.6 \\
4.0 \\
3.5\end{array}$ \\
\hline & --- & --- & 66 & $\cdots$ & --- & 1.1 & -- & --- & ${ }^{2} 13$ & --- & -- & 22 \\
\hline & --- & --- & $\begin{array}{c}65 \\
3(42)\end{array}$ & ---- & --- & $\begin{array}{c}1.5 \\
3(.9)\end{array}$ & -- & --- & $\begin{array}{c}36 \\
3(36)\end{array}$ & $-\cdots$ & -- & $\begin{array}{c}20 \\
8(20)\end{array}$ \\
\hline
\end{tabular}

Material lost during fire assay.
2 Contribution of only those fractions whose specific gravity was less than 3.3 .

6 months previous to the experiment to determine gold concentration

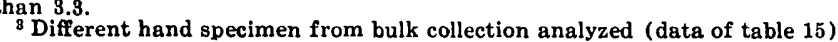
according to density fractions. The agreement is good, in view of the according to density fractions. The
heterogeneous nature of these samples. 
Perhaps the Butte Quartz Monzonite is best known as the host rock for the rich copper deposits in the Butte district, which have yielded 2,506,253 ounces of gold as a byproduct through 1964 (Meyer and others, 1968, p. 1376).

Fresh samples of Butte Quartz Monzonite collected very near mineralized zones are no higher in gold (typically less than $1 \mathrm{ppb}$ and averaging 0.6 $\mathrm{ppb}$ ) than fresh samples collected from exposure areas nearly devoid of mineralized zones (table 21 ). For example, fresh samples from a 4,000-foot borehole in the midst of the Butte district proper and within tens of feet of intensely mineralized zones have no more than $2.5 \mathrm{ppb}$ gold; values equal to or greater than $0.7 \mathrm{ppb}$, except for sample 2650, are associated with a copper content four times higher than the average for the entire core and reflect the presence of a few thin sulfide veinlets $(0.5-1.5 \mathrm{~mm}$ in width) (table 14). Furthermore, a gold content in excess of $5 \mathrm{ppb}$ is observed only for strongly hydrothermally altered samples of Butte Quartz Monzonite from underground workings (table 15).

TABLE 14.-Distribution of gold and copper in a drill core (DDH-B-3) in Butte Quartz Monzonite, Butte district, Silver Bow County, Mont.

[Samples provided by David D. Blackwell, Southern Methodist Univ. and E. C. Robertson, U.S. Geol. Survey. Spectrographic analyses for copper by Sol
Berman, U.S. Geol. Survey]

\begin{tabular}{ccc}
\hline Depth (feet) & Au (ppb) & Cu (ppm) \\
\hline 850 & 0.6 & 32 \\
950 & .3 & 19 \\
1,050 & .3 & 87 \\
1,150 & .2 & 52 \\
1,350 & .3 & 20 \\
1,850 & .5 & 67 \\
2,150 & .3 & 91 \\
2,250 & .1 & 13 \\
2,430 & .7 & 350 \\
2,550 & .5 & 59 \\
2,650 & 1.3 & 24 \\
2,750 & .3 & 16 \\
2,850 & .4 & 17 \\
2,950 & .6 & 20 \\
3,050 & 2.4 & 320 \\
1,050 & 0.6 & 32 \\
3,160 & .5 & 32 \\
3,500 & .5 & 7 \\
3,550 & .6 & 380 \\
3,995 & 1.2 & 85 \\
& .6 &
\end{tabular}

TABLE 15.-Distribution of gold and copper in some samples of Butte Quartz Monzonite from underground workings in the Butte district, Montana

[Samples collected by E. C. Robertson, U.S. Geol. Survey. The samples vary considerably in degree of hydrothermal alteration and sulfide content.
Spectrographic analysis of copper by Sol Berman, U.S. Geol. Survey]

\begin{tabular}{|c|c|c|c|c|}
\hline Sample No. & Mine & Depth (feet) & $\mathrm{Au}(\mathrm{ppb})$ & $\mathrm{Cu}(\mathrm{ppm})$ \\
\hline 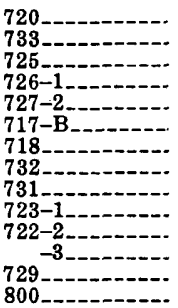 & 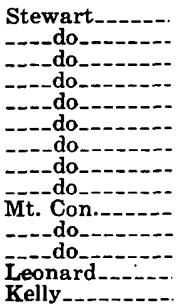 & $\begin{array}{l}3,400 \\
3,800 \\
3,900 \\
4,000 \\
4,000 \\
4,100 \\
4,100 \\
4,200 \\
4,400 \\
4,200 \\
5,000 \\
5,000 \\
2,000 \\
4,600\end{array}$ & $\begin{array}{r}19.8 \\
.9 \\
36.5 \\
21.0 \\
5.1 \\
10.3 \\
1.6 \\
4.8 \\
42.2 \\
11.0 \\
.2 \\
1.9 \\
4.5 \\
4.3\end{array}$ & $\begin{array}{r}4,600 \\
78 \\
1,900 \\
4,100 \\
1,700 \\
2,700 \\
370 \\
740 \\
800 \\
2,400 \\
92 \\
52 \\
580 \\
2,300\end{array}$ \\
\hline
\end{tabular}

This apparent relation between higher than average gold content and degree of alteration as qualitatively indicated by copper concentration is well demonstrated in figure 11, which shows the very restricted field occupied by fresh samples in contrast to the large scatter and high gold and copper values found for the altered samples.

Thus, we conclude that the primary abundance of gold in the Butte Quartz Monzonite was low and typical of the "background levels" for unaltered igneous rocks. We infer further that the concentration of gold to exploitable levels is because of postcrystallization (secondary) introduction and has no direct, simple connection to the abundance of gold initially present in the magma which formed the Butte Quartz Monzonite. Paley, Murovtsev, and Borozenets (1967) reached a similar conclusion regarding gold abundance in two intrusions in Uzbekistan-that is, high gold abundances reflect secondary alteration and remobilization, not primary magmatic concentrations; in particular, a plot of amount of secondary sericite against gold content shows a well-defined positive correlation (fig. 12).

Data presented in this report bear on the conclusions reached by Mantei and Brownlow (1967) with reference to gold mineralization in the Marysville stock, a satellitic pluton of the Boulder batho-

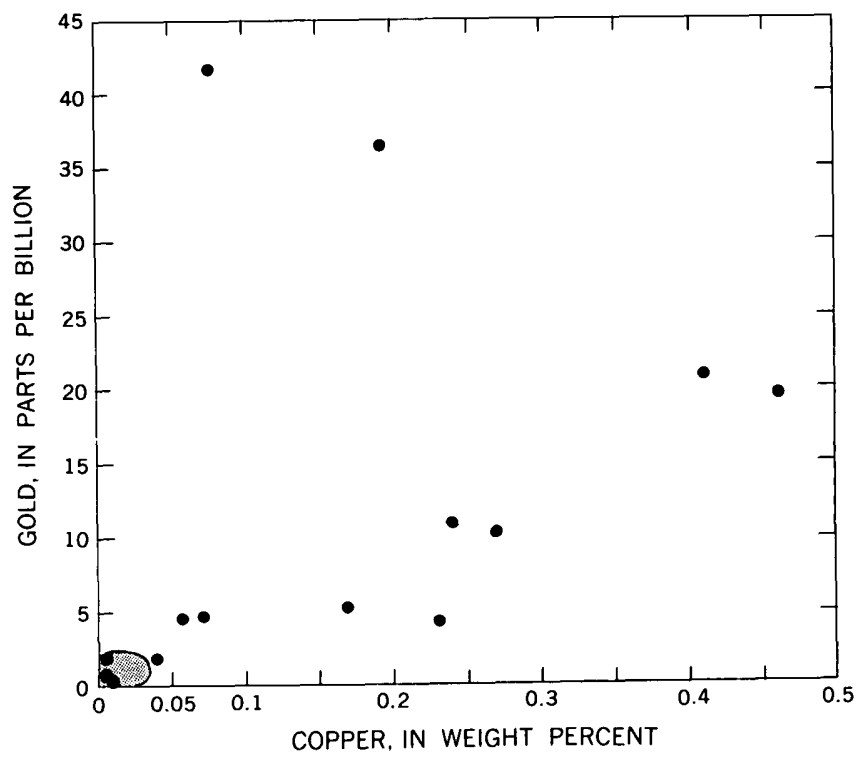

FigURE 11.-Variation of gold content with copper content in altered samples of Butte Quartz Monzonite from underground workings, Butte district, Montana (table 15). The patterned area represents unaltered samples of Butte Quartz Monzonite within the Butte district and elsewhere (tables 14 and 21). 


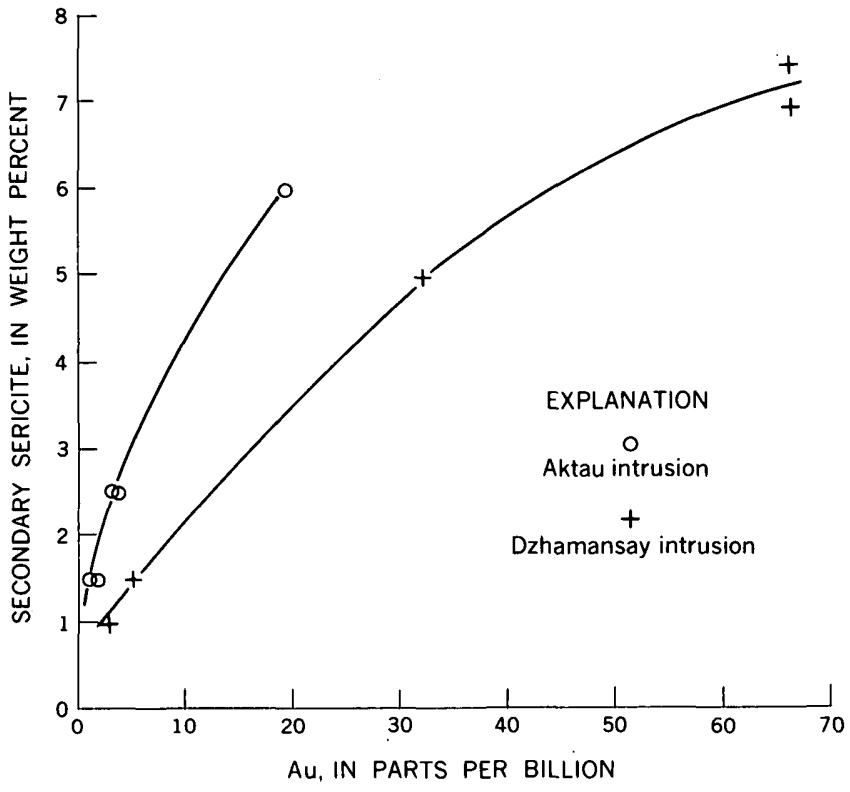

FIGURE 12.-Positive correlation of secondary sericite with gold abundance for samples from two intrusions in Uzbekistan, U.S.S.R. Data from Paley, Murovtsev, and Borozenets (1967).

lith that has yielded $1,145,800$ ounces of lode gold through 1959 (Koschmann and Bergendahl, 1968, p. 156). Mantei and Brownlow (1967, p. 234) concluded: “* ** gold of a crystallizing magma tends to be concentrated in the residual fluids $* * *$ to the extent of forming the ore veins at the edge of the stock." The extensive data now available clearly suggest to us that, if anything, gold tends to become depleted in the residual fluid as crystallization proceeds (p. 6).

Mantei and Brownlow, aware that the Marysville case may not be typical, suggested that "apparent concentration" of gold took place in the Marysville magma, but not in the Skaergaard intrusion of east Greenland (Vincent and Crocket, 1960a), because of a higher original content of gold. However, we have shown, from the preceding comparison of gold content in fresh versus hydrothermally altered Butte Quartz Monzonite, that low initial gold content in the rock is no deterrent to gold mineralization. Moreover, gold content for the five Marysville rocks analyzed by Mantei and Brownlow (1967) ranges between 4 and $89 \mathrm{ppb}$ and averages $34 \mathrm{ppb}$; hence, their values are anomalously high relative to values typical of unaltered plutonic rocks, that is, a general average of $2 \mathrm{ppb}$ or less (table 4 and fig. 3). We suggest that the samples studied by Mantei and Brownlow very likely have undergone alteration, such that the data do not permit estimates of the "original" gold content of the Marysville magma. ${ }^{3}$ To further complicate matters, though isotopic (potassium-argon) age data indicate that the Marysville stock (78 m.y., Baadsgaard and others, 1961) was emplaced within the same time span (68-78 m.y.) as the Boulder batholith (Tilling and others, 1968), the relation of the gold veins to the stock remains uncertain, and we cannot dismiss the possibility that gold mineralization at Marysville is not related to the stock at all, but rather to poststock (Miocene?) volcanism (Knopf, 1950). Thus, the relatively high gold abundance determined by Mantei and Brownlow (1967) for rocks and minerals of the Marysville stock can alternatively be interpreted as reflecting introduction by postmagmatic processes that may well have occurred considerably later than, and completely unrelated to, stock emplacement.

\section{DILLSBURG AND CORNWALl DISTRICTS, PENNSYLVANIA}

The Dillsburg and Cornwall intrusions are mineralogically and chemically similar and show ironenrichment differentiation trends, the degree of enrichment being greater in the Dillsburg sheet (Lapham, 1968). In addition to the magnetite deposits (limestone replacement) associated with both these intrusions, the only gold produced in any significant quantity in Pennsylvania (37,459 ounces through 1959) comes from the Cornwall mine; the gold is recovered from copper concentrates (chalcopyrite) associated with the magnetite ore (Koschmann and Bergendahl, 1968, p. 231). Hotz (1953) believed that the magnetite ore at Dillsburg was derived directly from the adjacent diabase sheet by volatile-rich, iron-bearing fluids being expelled just before the sheet consolidated at its present level. However, Lapham (1968) has summarized geologic evidence supporting the thesis that, at Cornwall, ore mineralization occurred a finite, but unknown, interval of time after the solidification of the chilled margin of the diabase sheet; he has postulated that ore fluids, rather than being derived from the crystallizing diabase at its present level, originated by fractionation from the diabase magma as it differentiated in a deeper seated source area. In any case, mineralization in both areas is linked in some manner to the magma which produced the diabase-granophyre intrusions.

The Dillsburg intrusion has had a complex petrologic history, and one of its unusual petrochemical

${ }^{3}$ Recently completed geochemical profiles across many veins in the Marysville stock show anomalies in metal content over the immediate vicinity of the veins, but away from the zones of mineralization, gold abundance in the rock can be as low as the value for unaltered plutonic rocks, that is, in the range of 1-2 ppb (Mantei and others, 1970). 
features, as compared with the Cornwall and other diabase-granophyre suites, is the abnormally high degree of iron enrichment characteristic of rocks formed during the intermediate stages of crystallization. Hotz (1953) suggested that during this stage volatile-rich fluids, generated lower in the crystallizing sheet, were apparently capable of mobilizing iron and ultimately depositing magnetite in the overlying sedimentary strata; the development of late hydrous silicates (at the expense of pyroxene) and of other alteration products, Hotz postulated, also mark the passage of hydrothermal fluids through the system. Davidson and Wyllie (1968), utilizing detailed optical observations and electronprobe analyses, have demonstrated the breakdown of primary iron and titanium oxides in many rocks of the Dillsburg intrusion; this breakdown leaves skeletal ilmenite and forms a second-generation, low-titanium magnetite; Davidson and Wyllie attributed the origin of secondary hydrous minerals to the same alteration process.

We have shown (p. 12) that gold content for the Dillsburg intrusion and the one chilled margin sample from Cornwall is distinctly higher relative to other samples of chilled margins of dikes in the same area; gold content is also higher than in other suites from the Triassic basin of the Eastern United States, not to mention compositionally similar rocks elsewhere. These high concentrations, we suggest, reflect alteration effects, not primary features. It is significant to note that the high gold content of the Dillsburg rocks is matched by a high copper content (fig. 10). Although the mechanism contributing to these anomalously high gold content is obscure, available geologic and petrographic evidence indicate that ample opportunity existed for the redistribution and concentration of gold by late-stage fluids, which caused alteration and replacement of primary oxide and silicate minerals and which resulted in the magnetite deposits. Moreover, the Cornwall intrusion represents another example of gold production from a mineralization associated with a host rock whose primary gold ábundance is not significantly higher or lower than "background levels" for the province as a whole.

\section{JEROME DISTRICT, CENTRAL ARIZONA}

Because of its close association with sulfides, gold is economically important in all the mines of the Jerome district; approximately 1,890,000 ounces of byproduct gold have been produced from the area, principally from the United Verde and United Verde extension copper mines (Anderson and
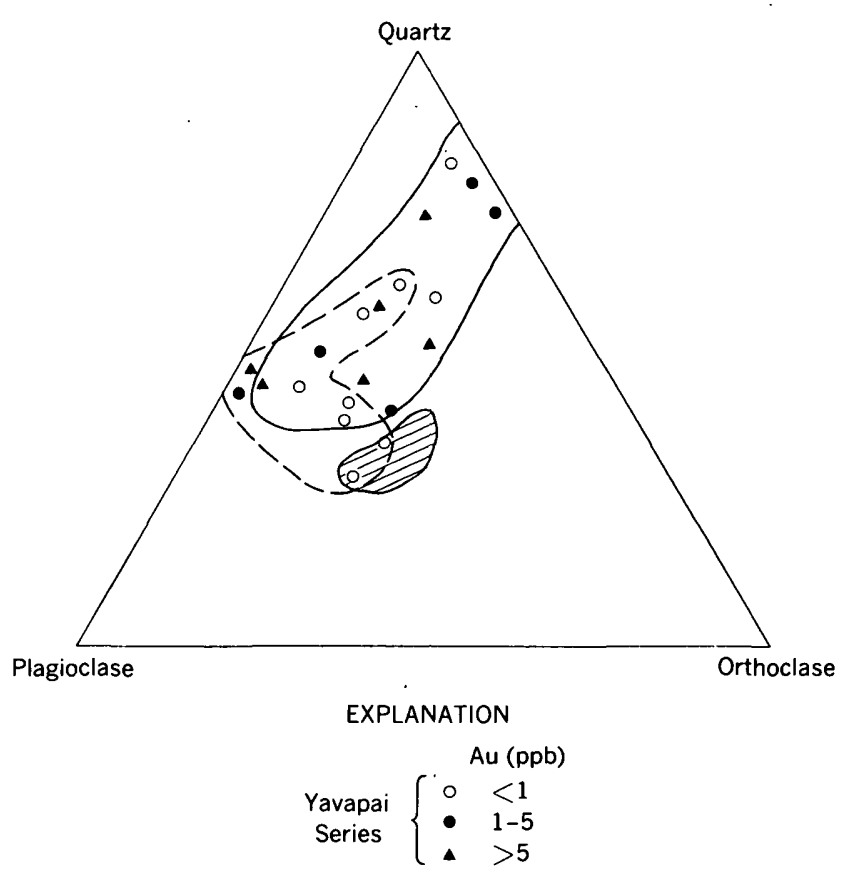

FigURE 13.-Normative plagioclase, orthoclase, quartz, and variation in gold content of Precambrian rhyolites and quartz porphyry of the Yavapai Series, central Arizona. Solid line encloses field for samples of quartz porphyry and of the Ash Creek Group; dashed line encloses field for samples of the Alder Group. Patterned area represents young unaltered glassy rhyolitic rocks from Wyoming and California, all of which contain less than $1 \mathrm{ppb}$ gold. Normative data from Anderson (1968, fig. 6) ; goldabundance data from table 39 .

Creasey, 1958). Anderson (1968) has ably documented the complex relationships between metamorphism, metasomatism, and hydrothermal alteration of the silicic volcanic rocks of the Yavapai Series (Precambrian).

As noted by Anderson (1968), chemical data indicate that the rhyolites as a group are characterized by a low total-alkali content and highly variable ratios of sodium to potassium, as compared with fresh rhyolitic obsidians from elsewhere in the Western United States (fig. 13). In addition, Anderson demonstrated that iron-magnesium metasomatism (iron and magnesium were probably derived from older basaltic rocks) has affected some of the rhyolites. Rocks of the Alder Group are more uniform in alkali content (expressed in terms of normative feldspars) than those of the Ash Creek Group or of the quartz porphyry (Anderson, 1968, fig. 6). Gold content of samples of the Alder Group is less than $1 \mathrm{ppb}$ except for two samples (fig. 13); significantly, those two samples have an anomalously low potassium (hence, normative Or) content, less than 0.22 percent $\mathrm{K}_{2} \mathrm{O}$ rather than the range of 
1.6-4.0 percent for the other samples of the group (Anderson, 1968, table 3).

Rhyolites of the Ash Creek Group tend to have not only a higher iron content than those of the Alder Creek but also a more variable and lower alkali content. Not too surprisingly, gold content in these rocks is likewise extremely variable but, on the whole, much higher. The highest gold values observed for the Ash Creek Group are for two chloritized samples (table 39, Nos. 4 and 5) underlain by basalt. Similarly, the quartz porphyry is characterized by a variable alkali content and, accordingly, a variable but relatively high gold content (table 39 and fig. 13).

Thus, we conclude from our data and those of Anderson (1968) that a gross correlation exists between variable but relatively high gold content and variable and lower alkali content (also higher iron content). In other words, these results strongly suggest that gold enrichment in these rocks is related to secondary processes, which caused loss of alkalis and apparent gain of iron and magnesium, and therefore has no direct relationship to variations in primary gold abundance.

\section{BULLFROG DISTRICT, NYE COUNTY, NEV.}

Gold production from the Bullfrog district through 1959 was 120,400 ounces (Koschmann and Bergendahl, 1968, p. 191). According to Cornwall and Kleinhampl (1964), most of the gold and silver deposits are in fissures and veins related to normal faults; these faults occur either near the rim of the Bullfrog Hills caldera or near the contact between the central domal uplift, where basement rocks are exposed, and the Tertiary pyroclastic material within the caldera. Cornwall and Kleinhampl suggested that the ore-bearing solutions were probably derived from a magma chamber beneath the present location of the caldera. Except for the three closely associated altered samples (2.0-22 ppb gold, table 40) thought to be part of the lower part of the caldera, the rhyolites, latites, and basalts associated with the caldera do not contain any more gold than their unaltered counterparts from elsewhere in the Western United States (table 7). Again, we suggest the occurrence of gold mineralization in this region is not obviously, if at all, related to primary gold abundances in the host rocks. It is perhaps worthwhile to note that our interpretation of data for gold mineralization in the Bullfrog district, which is underlain by Tertiary volcanic rocks, does not differ in principle for mineralization of the Jerome district, Arizona, which is underlain in large part by Precambrian volcanic rocks of grossly similar lithology.

\section{THE MOTHER LODE, CALIFORNIA}

The Mother Lode of California, a belt about 120 miles long and 1-4 miles wide in the western foothills of the Sierra Nevada, has yielded through 1959 about 13,300,000 ounces of lode and byproduct gold, that is, roughly a third of total lode and byproduct production from California (from data compiled by Koschmann and Bergendahl, 1968). The host rocks for the ore deposits are metamorphic rocks (slates, schists, and greenstones) of Jurassic and Carboniferous age which have been intruded by plutonic rocks ranging in composition from peridotite (serpentinized) to granodiorite.

Many of the world's largest primary gold deposits occur within granite-greenstone terranes similar to that hosting the Mother Lode. From studies mainly on such deposits in Precambrian greenstone belts of Canada and South Africa, many previous investigators have advocated the hypothesis that the gold ultimately had its source in the volcanic and clastic country rocks, rather than in the granitic intrusions (Macgregor, 1951; Boyle, 1960). In contrast, Knopf (1929) suggested that the source of gold in the Mother Lode was the magma from which the granitic rocks were derived. Unfortunately, only extremely limited quantitative abundance data on gold in rocks from such greenstone-granite associations are available to test these conflicting hypotheses.

Viljoen, Saager, and Viljoen (1969) reported average values of gold for samples of the country rock of the Steynsdorp Goldfield, South Africa (metabasalt and ultramafic rocks, 5-20 ppb; tuffaceous shale, $75 \mathrm{ppb}$ ), higher than the average value for the Steynsdorp granite $(<5 \mathrm{ppb})$ which intrudes them. However, it should be noted that Viljoen, Saager, and Viljoen claimed only a sensitivity of $5 \mathrm{ppb}$ for their gold determinations. Nonetheless, on the basis of gold abundance data, along with other geologic and geochemical arguments, Viljoen, Saager, and Viljoen contended that the gold was derived from the country rock, not the intruding granite.

Our more precise, but nonetheless limited, data on Mother Lode (table 16) show that, excluding the relatively high value of one of the slate samples $(30.6 \mathrm{ppb})$, the gold content of the country rock is typical for basic and intermediate volcanic rocks and is not appreciably different from that for rocks of the Sierra Nevada batholith. We emphasize, how- 
ever, that no data on gold abundance are available for granitic rocks within the Mother Lode district and that, inasmuch as the greenstones are presumably regionally metamorphosed volcanic rocks, their gold abundance may not necessarily represent primary abundances.

TABLE 16.-Comparison of gold concentration in samples of host rocks from the Mother Lode district with samples from the Sierra Nevada batholith

\begin{tabular}{|c|c|c|c|c|}
\hline Suite or location & Rock type & $\begin{array}{l}\text { Number } \\
\text { of } \\
\text { samples }\end{array}$ & $\begin{array}{l}\text { Range } \\
\text { (ppb) }\end{array}$ & $\begin{array}{l}\text { Average } \\
\text { gold } \\
\text { content } \\
\text { (ppb) }\end{array}$ \\
\hline Mother Lode district_--- & Metavolcanics & 5 & $1.2-3.4$ & 2.1 \\
\hline \multirow[t]{2}{*}{$\begin{array}{l}\text { Sierra Nevada } \\
\text { batholith. }\end{array}$} & $\begin{array}{l}\text { Slate } \\
\text { Quartz diorite-- } \\
\text { Granodiorite -- } \\
\text { Quartz monzonite }\end{array}$ & $\begin{array}{r}2 \\
1 \\
11\end{array}$ & $\begin{array}{r}3.6-30.6 \\
-.4-5.2\end{array}$ & $\begin{array}{l}\overline{1.4} \\
1.5\end{array}$ \\
\hline & $\begin{array}{l}\text { to alaskite. } \\
\text { to }\end{array}$ & 5 & $.3-1.3$ & .8 \\
\hline
\end{tabular}

1 Data from table 19.

Thus, the meager data presently available to us makes it premature to speculate as to the source of the gold in these major deposits in greenstonegranite terranes. In view of the important economic benefits that might accrue, a comprehensive investigation, within the framework of background data given in this reconnaissance report, on the gold geochemistry of the Mother Lode and other deposits in similar settings is clearly needed before the critical questions of the source and of the concentration of gold can be answered.

\section{THERMAL SPRINGS, YELLOWSTONE NATIONAL PARK,} WYO.

The association of epithermal gold and silver deposits with volcanic hot springs or thermal activity is not uncommon and has been discussed in detail by White (1955). For example, in the Yellowstone area, the formation of veinlets of auriferous pyrite from thermal waters of Monarch Geyser (Norris Basin) has been noted by Weed (1905). For the Taupo Volcanic Zone, New Zealand, Weissberg (1969) reported high concentrations of gold (as much as $85,000 \mathrm{ppb}$ ), silver, mercury, arsenic, antimony, and thallium in siliceous sinters and precipitates currently depositing from thermal waters containing only 0.04 ppb gold; Weissberg, however, did not present data on gold content in the volcanic rocks through which the thermal waters course.

J. J. Rowe and others of the U.S. Geological Survey are currently investigating the gold content of the thermal waters and their precipitates in Yellowstone National Park. Preliminary data indicate that gold content is very low in the thermal waters, generally $0.004-0.040 \mathrm{ppb}$, yet rather high in sinters depositing from such waters, generally 5-50 ppb but up to $5,000 \mathrm{ppb}$ (table 17). Sinters having high gold concentrations also contain correspondingly higher amounts of arsenic, antimony, and mercury. On the other hand, the host rhyolites of the thermal springs system only contain low amounts of gold, 0.1-1.3 ppb (table 38).

TABLE 17.-Ranges of gold content in rhyolite, thermal waters, and precipitates from thermal waters, Yellowsione National Park, Wyo.

[From table 38 and preliminary unpublished data]

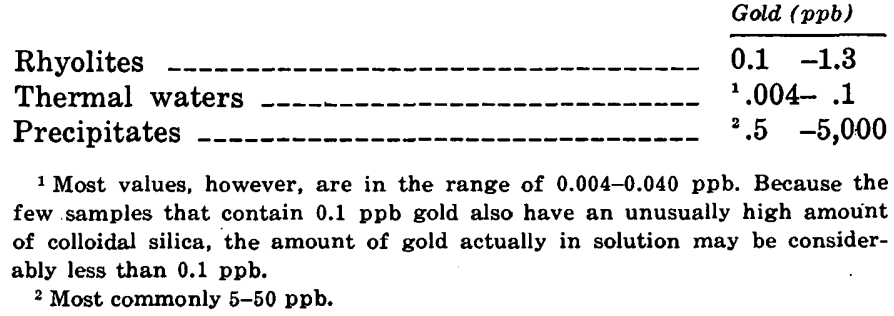

These results are in general accord with those of Weissberg (1969) and likewise indicate that precipitates having high concentrations of gold, nearly ore grade, are actively forming from solutions having very low gold levels. Furthermore, our data show that above-average gold concentration in the country rock is not required for the rocks to serve as a possible source for the gold. The rhyolites of the Yellowstone area, for example, could readily supply all the gold in the thermal systems (including precipitates) by yielding about 10 percent or so of their original content. Calculations by Weissberg (1969), based on discharge rates and life span of the Wairakei geothermal system in New Zealand, indicate that a strong argument can be made for the formation of some economic epithermal gold deposits by precipitation from dilute hydrothermal solutions.

These collective results bear on, and render somewhat moot, the question of the ultimate source of the gold (and perhaps of other metals) in metallization processes. One rather obvious implication is, of course, that gold mineralization bears no simple relationship to known or assumed primary gold abundance of the host rock and that mechanisms of gold transport (or remobilization) and deposition (or redeposition), rather than initial concentrations, play the dominant role in gold mineralization.

\section{REFERENCES}

Anderson, C. A., 1940, Hat Creek lava flow: Am. Jour. Sci., v. 238 , no. 7 , p. $477-492$.

1941, Volcanoes of the Medicine Lake Highland, California: California Univ. Dept. Geol. Sci. Bull., v. 25, no. 7 , p. $347-422$. 
-1968, Metamorphosed Precambrian silicic volcanic rocks in central Arizona: Geol. Soc. America Mem. 116, p. 9-44.

Anderson, C. A., and Creasey, S. C., 1958, Geology and ore deposits of the Jerome area, Yavapai County, Arizona: U.S. Geol. Survey Prof. Paper 308, 185 p.

Baadsgaard, Halfdan, Folinsbee, R. E., and Lipson, J. I., 1961, Potassium-argon dates of biotites from Cordilleran granites: Geol. Soc. America Bull., v. 72, no. 5, p. 689702.

Bailey, R. A., Smith, R. L., and Ross, C. S., 1969, Stratigraphic nomenclature of volcanic rocks in the Jemez Mountains, New Mexico: U.S. Geol. Survey Bull. 1274-P, $19 \mathrm{p}$.

Barrell, Joseph, 1907, Geology of the Marysville mining district, Montana: U.S. Geol. Survey Prof. Paper 57, 178 p.

Bateman, P. C., Clark, L. D., Huber, N. K., Moore, J. G., and Rinehart, C. D., 1963, The Sierra Nevada batholith-a synthesis of recent work across the central part: U.S. Geol. Survey Prof. Paper 414-D, 46 p.

Bateman, P. C., and Eaton, J. P., 1967, Sierra Nevada batholith: Science, v. 158, no. 3807, p. 1407-1417.

Bell, Henry, 1969, The regional setting of hydrothermal alteration in part of South Carolina and North Carolina [abs.]: Geol. Soc. America, Abstracts with Programs for 1969 , pt. 7, p. 300 .

Billings, M. P., 1928, The petrology of the North Conway quadrangle in the White Mountains of New Hampshire: Am. Acad. Arts Sci. Proc., v. 63, no. 3, p. 67-137.

Boyd, F. R., 1961, Welded tuffs and flows in the rhyolite plateau of Yellowstone Park, Wyoming: Geol. Soc. America Bull., v. 72, no. 3, p. 387-426.

Boyle, R. W., 1960, The geology, geochemistry, and origin of the gold deposits of the Yellowknife district: Canada Geol. Survey Mem. 310, 193 p.

Broderick, T. M., 1935, Differentiation in lavas of the Michigan Keweenawan: Geol. Soc. America Bull., v. 46, no. 4, p. 503-558.

Broderick, T. M., and Hohl, C. D., 1935, Differentiation in traps and ore deposition: Econ. Geology, v. 30, no. 3, p. 301-312.

Butler, J. R., and Ragland, P. C., 1969, Petrology and chemistry of meta-igneous rocks in the Albermarle area, North Carolina slate belt: Am. Jour. Sci., v. 267, no. 6, p. 700-726.

Chapman, R. W., and Williams, C. R., 1935; Evolution of the White Mountain magma series: Am. Mineralogist, v. 20, no. 7 , p. 502-530.

Clifton, H. E., Hunter, R. E., Swanson, F. J., and Phillips, R. L., 1969, Sample size and meaningful gold analysis: U.S. Geol. Survey Prof. Paper 625-C, 17 p.

Cooper, Margaret, 1971, Selected annotated bibliography on the geochemistry of gold: U.S. Geol. Survey Bull. 1337, $63 \mathrm{p}$.

Cornwall, H. R., 1951a, Differentiation in lavas of the Keweenawan series and the origin of the copper deposits of Michigan: Geol. Soc. America Bull., v. 62, no. 2, p. 159-202.

-1951b, Differentiation in magmas of the Keweenawan series: Jour. Geology, v. 59, no. 2, p. 151-172.

-1951c, Ilmenite, magnetite, hematite, and copper in lavas of the Keweenawan series: Econ. Geology, v. 46, no. 1 , p. 51-67.
Cornwall, H. R., 1962, Calderas and associated rocks near Beatty, Nye County, Nevada, in Geological Society of America, Petrologic studies-A volume in honor of A. F. Buddington: New York, p. 357-371.

Cornwall, H. R., and Kleinhampl, F. J., 1964, Geology of Bullfrog quadrangle and ore deposits related to Bullfrog Hills caldera, Nye County, Nevada, and Inyo County, California: U.S. Geol. Survey Prof. Paper 454-J, 25 p.

Cornwall, H. R., and Rose, H. J., Jr., 1957, Minor elements in Keweenawan lavas, Michigan: Geochim. et Cosmochim. Acta, v. 12, no. 3, p. 209-224.

Covell, D. F., 1959, Determination of gamma-ray abundance directly from total absorption peak: Anal. Chemistry, v. 31, p. 1785-1790.

Davidson, A., and Wyllie, P. J., 1968, Opaque oxide minerals of some diabase-granophyre associations in Pennsylvania: Econ. Geology, v. 63, no. 8, p. 950-960.

DeGrazia, A. R., and Haskin, Larry, 1964, On the gold content of rocks: Geochim. et Cosmochim. Acta, v. 28, p. $559-564$.

Desborough, G. A., 1963, Mobilization of iron by alteration of magnetite-ulvöspinel in basic rocks in Missouri: Econ. Geology, v. 58, no. 3, p. 332-346.

1967, Closed system differentiation of sulfides in olivine diabase, Missouri: Econ. Geology, v. 62, no. 5, p. 595-613.

Dodge, F. C. W., and Ross, D. C., 1971, Coexisting hornblendes and biotites from granitic rocks near the San Andreas fault, California: Jour. Geology, v. 79, no. 2, p. 158-172.

Dodge, F. C. W., Smith, V. C., and Mays, R. E., 1969, Biotites from granitic rocks of the central Sierra Nevada batholith, California: Jour. Petrology, v. 10, no. 2, p. 250-271.

Doe, B. R., Tilling, R. I., Hedge, C. E., and Klepper, M. R., 1968, Lead and strontium isotope studies of the Boulder batholith, southwestern Montana: Econ. Geology, v. 63, no. 8, p. 884-906.

Doell, R. R., Dalrymple, G. B., Smith, R. L., and Bailey, R. A., 1968, Paleomagnetism, potassium-argon ages, and geology of rhyolites and associated rocks of the Valles caldera, New Mexico: Geol. Soc. America Mem. 116, p. 211-248.

Ehmann, W. D., Baedecker, P. A., and McKown, D. M., 1970, Gold and iridium in meteorites and some selected rocks: Geochim. et Cosmochim. Acta, v. 34, p. 493-507.

Emmons, W. H., 1937, Gold deposits of the world: New York, McGraw-Hill Book Co., Inc., 562 p.

Engel, A. E. J., Engel, C. G., and Havens, R. G., 1965, Chemical characteristics of oceanic basalts and the upper mantle: Geol. Soc. America Bull., v. 76, no. 7, p. 719-734.

Finch, R. H., and Anderson, C. A., 1930, The quartz basalt eruptions of Cinder Cone, Lassen Volcanic National Park, California: California Univ. Dept. Geol. Sci. Bull., v. 19 , no. 10 , p. $245-273$.

Fiske, R. S., Hopson, C. A., and Waters, A. C., 1963, Geology of Mount Rainier National Park, Washington: U.S. Geol. Survey Prof. Paper 444, 93 p.

Gast, P. W., 1965, Terrestrial ratio of potassium to rubidium and the composition of the Earth's mantle: Science, v. 147 , no. 3660 , p. $858-860$. 
Gottfried, David, Greenland, L. Paul, and Campbell, E. Y., 1968, Variation of $\mathrm{Nb}-\mathrm{Ta}, \mathrm{Zr}-\mathrm{Hf}$, Th-U, and $\mathrm{K}-\mathrm{Cs}$ in two diabase-granophyre suites: Geochim. et Cosmochim. Acta, v. 32, p. 925-948.

Gottfried, David, Moore, Roosevelt, and Caemmerer, Alice, 1962, Thorium and uranium in some alkalic igneous rocks from Virginia and Texas, in Short papers in geology, hydrology, and topography: U.S. Geol. Survey Prof. Paper 450-B, p. B70-B72.

Gottfried, David, Rowe, J. J., Tilling, R. I., and Dodge, F. C. W., 1969, Geochemical behavior of gold during magmatic differentiation [discussion paper]: Geol. Soc. America, Abstracts with Programs for 1969, pt. 7, p. 277-278.

Greenland, L. P., and Lovering, J. F., 1966, Fractionation of fluorine, chlorine and other trace elements during differentiation of a tholeiitic magma: Geochim. et Cosmochim. Acta, v. 30, p. 963-982.

Hamilton, Warren, 1959, Yellowstone Park area, Wyominga possible modern lopolith: Geol. Soc. America Bull., v. 70, no. 2, p. 225-228.

- 1963, Petrology of rhyolite and basalt, northwestern Yellowstone Plateau, in Short papers in geology and hydrology: U.S. Geol. Survey Prof. Paper 475-C, p. C78-C81.

-1965, Geology and petrogenesis of the Island Park caldera of rhyolite and basalt, eastern Idaho: U.S. Geol. Survey Prof. Paper 504-C, 37 p.

Heier, K. S., Compston, W., and McDougall, I., 1965, Thorium and uranium concentrations, and the isotopic composition of strontium in the differentiated Tasmanian dolerites: Geochim. et Cosmochim. Acta, v. 29, p. 643659.

Hotz, P. E., 1953, Petrology of granophyre in diabase near Dillsburg, Pennsylvania: Geol. Soc. America Bull., v. 64, no. 6, p. 675-704.

Hurlbut, C. S., Jr., 1939, Igneous rocks of the Highwood Mountains, Montana-Part I, The laccoliths: Geol. Soc. America Bull., v. 50, no. 7, p. 1043-1112.

Jones, R. S., 1969, Gold in igneous, sedimentary, and metamorphic rocks: U.S. Geol. Survey Circ. 610,28 p.

Jones, R. S., and Fleischer, Michael, 1969, Gold in minerals and the composition of native gold: U.S. Geol. Survey Circ. 612,17 p.

Keays, R. R., Ganopathy, R., Laul, J. C., Anders, Edward, Herzog, G. G., and Jeffrey, P. M., 1970, Trace elements and radioactivity in lunar rocks-implications for meteorite infall, solar-wind flux, and formation condition of Moon: Science, v. 167, no. 3918, p. 490-493.

Knopf, Adolf, 1913, Ore deposits of the Helena mining region, Montana: U.S. Geol. Survey Bull. 527, 143 p. 1929, The Mother Lode system of California: U.S. Geol. Survey Prof. Paper 157, 88 p.

1950, The Marysville granodiorite stock, Montana: Am. Mineralogist, v. 35, no. 9-10, p. 834-844.

1957, The Boulder batholith of Montana: Am. Jour. Sci., v. 255 , no. 2 , p. 81-103.

Koschmann, A. H., and Bergendahl, M. H., 1968, Principal gold-producing districts of the United States: U.S. Geol. Survey Prof. Paper 610, $283 \mathrm{p}$.

Krauskopf, K. B., 1967, Source rocks for metal-bearing fluids, in Barnes, H. L., ed., Geochemistry of hydrothermal ore deposits: New York, Holt, Rinehart and Winston, p. 1-33.
Lapham, D. M., 1968, Triassic magnetite and diabase at Cornwall, Pennsylvania, in Ridge, J. D., ed., Ore deposits of the United States, 1933-1967 (Graton-Sales Volume), Volume 1: New York, Am. Inst. Mining, Metall., and Petroleum Engineers, p. 72-94.

Larsen, E. S., Jr., 1940, Petrographic province of central Montana: Geol. Soc. America Bull., v. 51, no. 6, p. 887948.

-1948, Batholith and associated rocks of Corona, Elsinore, and San Luis Rey quadrangles, southern California: Geol. Soc. America Mem. 29, 182 p.

Larsen, E. S., Jr., and Gottfried, David, 1961, Distribution of uranium in rocks and minerals of Mesozoic batholiths in Western United States: U.S. Geol. Survey Bull. 1070-C, p. 63-102.

Larsen, E. S., Jr., and Schmidt, R. G., 1958, A reconnaissance of the Idaho batholith and comparison with the southern California batholith: U.S. Geol. Survey Bull. 1070-A, $33 \mathrm{p}$.

Lonsdale, J. T., 1940, Igneous rocks of the TerlinguaSolitario region, Texas: Geol. Soc. America Bull., v. 51, no. 10, p. 1539-1626.

Lonsdale, J. T., and Maxwell, R. A., 1949, Petrology of Big Bend National Park, Texas [abs.]: Geol. Soc. America Bull., v. 60 , no. 12 , pt. 2 , p. 1906.

Lovering, T. S., and Goddard, E. N., 1950, Geology and ore deposits of the Front Range, Colorado: U.S. Geol. Survey Prof. Paper 223, 319 p.

Macdonald, G. A., 1949, Petrography of the island of $\mathrm{Ha}$ waii: U.S. Geol. Survey Prof. Paper 214-D, p. 51-96. 1969, Petrology of the basalt cores from Midway atoll: U.S. Geol. Survey Prof. Paper 680-B, 10 p.

Macdonald, G. A., and Eaton, J. P., 1964, Hawaiian volcanoes during 1955: U.S. Geol. Survey Bull. 1171, 170 p.

Macdonald, G. A., and Powers, H. A., 1946, Contribution to the petrography of Haleakala Volcano, Hawaii: Geol. Soc. America Bull., v. 57, no. 1, p. 115-124.

McDougall, Ian, 1962, Differentiation of the Tasmanian dolerites-Red Hill dolerite-granophyre association: Geol. Soc. America Bull., v. 73, no. 3, p. 279-316.

1964, Differentiation of the Great Lake dolerite sheet, Tasmania: Geol. Soc. Australia Jour., v. 11, pt. 1. p. 107-132.

McDougall, Ian, and Lovering, J. F., 1963, Fractionation of chromium, nickel, cobalt and copper in a differentiated dolerite-granophyre sequence at Red Hill, Tasmania: Geol. Soc. Australia Jour., v. 10, pt. 2, p. 325-338.

McDowell, F. W., and Kulp, J. L., 1969, Potassium-argon dating of the Idaho batholith: Geol. Soc. America Bull., v. 80 , no. 11 , p. 2379-2382.

Macgregor, A. M., 1951, The primary source of gold: South African Jour. Sci., v. 47, no. 6, p. 157-161.

MacGregor, I. D., 1969, The system $\mathrm{MgO}_{-} \mathrm{SiO}_{2}-\mathrm{TiO}_{2}$ and its bearing on the distribution of $\mathrm{TiO}_{2}$ in basalts: $\mathrm{Am}$. Jour. Sci., v. 267-A, p. 342-363.

Mantei, E. J., Bolter, Ernst, and Al Shaieb, Zuhair, 1970, Distribution of gold, silver, copper, lead, and zinc in the productive Marysville stock, Montana: Mineralium Deposita, v. 5 , no. $2,184-190$.

Mantei, E. J., and Brownlow, A. H., 1967, Variation in gold content of minerals of the Marysville quartz diorite stock, Montana: Geochim. et Cosmochim. Acta, v. 31, no. 2, p. 225-235. 
Maxwell, R. A., and Lonsdale, J. T., 1949, General geology of Big Bend National Park, Texas [abs.]: Geol. Soc. America Bull., v. 60, no. 12, pt. 2, p. 1908.

Meyer, Charles, Shea, E. P., Goddard, C. C., Jr., and others, 1968, Ore deposits at Butte, Montana, in Ridge, J. D., ed., Ore deposits of the United States, 1933-1967 (Graton-Sales Volume), Volume 2: New York, Am. Inst. Mining, Metall., and Petroleum Engineers, p. 1373-1416.

Page, B. M., 1966, Geology of the Coast Ranges of California, in Bailey, E. H., ed., Geology of northern California: California Div. Mines and Geology Bull. 190, p. 255-276.

Paley, L. Z., Murovtsev, A. V., and Borozenets, N. I., 1967, The geochemistry of gold at Sultanuizdag: Geochemistry Internat., v. 4, no. 6, p. 1197-1201. (Translated from Uzbek. Geol. Zhur., no. 6; p. 50-55, 1967.)

Pardee, J. T., and Park, C. F., Jr., 1948, Gold deposits of the southern Piedmont: U.S. Geol. Survey Prof. Paper $213,156 \mathrm{p}$.

Peacock, M. A., 1931, Classification of igneous rock series: Jour. Geology, v. 39, p. 54-67.

Peck, D. L., Griggs, A. B., Schlicker, H. G., Wells, F. G., and Dole, H. M., 1964, Geology of the central and northern parts of the Western Cascade Range in Oregon: U.S. Geol. Survey Prof. Paper 449, 56 p.

Pecora, W. T., 1941, Structure and petrology of the Boxelder laccolith, Bearpaw Mountains, Montana: Geol. Soc. America Bull., v. 52, no. 6, p. 817-854.

Peterman, Z. E., Carmichael, I. S. E., and Smith, A. L., $1970, \mathrm{Sr}^{87} / \mathrm{Sr}^{86}$ ratios of Quaternary lavas of the Cascade Range, northern California: Geol. Soc. America Bull., v. 81, no. 1, 311-318.

Phan, K. D., 1965, Enquête sur l'or dans les roches-origine de l'or des gisements: Chronique Mines et Recherche Minière, v. 33 , no. 343 , p. $175-188$.

Powers, H. A., 1932, The lavas of the Modoc Lava-Bed quadrangle, California: Am. Mineralogist, v. 17, no. 7, p. 253-294.

-1955, Composition and origin of basaltic magma of the Hawaiian Islands: Geochim. et Cosmochim. Acta, v. 7, p. 77-107.

1960a, A distinctive chemical characteristic of Snake River basalts of Idaho, in Short papers in the geological sciences: U.S. Geol. Survey Prof. Paper 400-B, p. B298.

$-1960 \mathrm{~b}$, Alkalic lava flow, with fluidity of basalt, in the Snake River Plain, Idaho, in Short papers in the geological sciences: U.S. Geol. Survey Prof. Paper 400-B, p. B297.

Ragland, P. C., Rogers, J. J. W., and Justus, P. S., 1968, Origin and differentiation of Triassic dolerite magmas, North Carolina, U.S.A.: Contr. Mineralogy and Petrology, v. 20, no. 1, p. 57-80.

Rankin, D. W., 1970, Stratigraphy and structure of Precambrian rocks in northwestern North Carolina, in Fisher, G. W., Pettijohn, F. J., Reed, J. C., Jr., and Weaver, K. N., eds., Studies in Appalachian geologycentral and southern: New York, Intersci. Pubs., p. 227-245.

Rankin, D. W., Stern, T. W., Reed, J. C., Jr., and Newell, M. F., 1969, Zircon ages of felsic volcanic rocks in the upper Precambrian of the Blue Ridge, Appalachian Mountains: Science, v. 166 , no. 3906, p. $741-744$.
Ross, C. S., Smith, R. L., and Bailey, R. A., 1961, Outline of the geology of the Jemez Mountains, New Mexico, in New Mexico Geol. Soc. Guidebook of the Albuquerque country, 12th Field Conf., Oct. 6-8, 1961: Socorro, New Mexico Bur. Mines and Mineral Resources, p. 139-143.

Rowe, J. J., 1969, Fractionation of gold in a differentiated tholeiitic dolerite: Chem. Geology, v. 4, p. 421-427.

Rowe, J. J., and Simon, F. O., 1968, The determination of gold in geologic materials by neutron-activation analysis using fire assay for the radiochemical separations: U.S. Geol. Survey Circ. 599, 4 p.

Russell, R. J., 1928, Basin Range structure and stratigraphy of the Warner Range, northeastern California: California Univ. Pub., Dept. Geol. Sci. Bull., v. 17, no. 11, p. $387-496$.

Sandell, E. B., and Goldich, S. S., 1943, The rarer metallic constituents of some American igneous rocks: Jour. Geology, v. 51, p. 99-115.

Shcherbakov, Yu. G., 1968, Distribution of gold in igneous rocks and specialization of gold-bearing intrusions: Geochemistry Internat., v. 5, no. 6, p. 1226-1228. (Translated from Geokhimiya, no. 12, p. 1518-1520, 1968.)

Shcherbakov, Yu. G., and Perezhogin, G. A., 1963, [Geochemical relation between gold mineralization, intrusives, and the enclosing rocks in western Siberia]: Geokhimiya, 1963, no. 9, p. 851-858 (in Russian). (Translation in Geochemistry, v. 1, p. 882-890, 1963.)

1964, Geochemistry of gold: Geochemistry Internat., [v. 1,] no. 3 , p. 489-496. (Translated from Geokhimiya, no. 6 , p. $518-528,1964$.)

Shilin, N. L., 1968, Zoloto v porodakh tsentral' Kamchatki: Akad. Nauk SSSR Izv. Ser. Geol., 1968, no. 11, p. 69-76.

Smith, A. L., and Carmichael, I. S. E., 1968, Quaternary lavas from the southern Cascades, western U.S.A.: Contr. Mineralogy and Petrology, v. 19, no. 3, p. 212238.

Smith, R. L., and Bailey, R. A., 1966, The Bandelier tuffa study of ash-flow eruption cycles from zoned magma chambers: Bull. Volcanol., v. 29, p. 83-104. 1968, Resurgent cauldrons: Geol. Soc. America Mem. 116, p. 613-662.

Smith, R. L., Bailey, R. A., and Ross, C. S., 1970, Geologic map of the Jemez Mountains, New Mexico: U.S. Geol. Survey Misc. Geol. Inv. Map I-571, scale 1:125,000.

Stromquist, A. A., 1966, Bedrock geologic map of the Denton quadrangle, North Carolina: U.S. Geol. Survey open-file map.

Stromquist, A. A., and Sundelius, H. W., 1969, Stratigraphy of the Albemarle Group of the Carolina slate belt in central North Carolina: U.S. Geol. Survey Bull. 1274-B, $22 \mathrm{p}$.

Tatsumoto, Mitsunobu, Hedge, C. E., and Engel, A. E. J., 1965, Potassium, rubidium, strontium, thorium, uranium, and the ratio of strontium- 87 to strontium- 86 in oceanic tholeiitic basalt: Science, v. 150 , no. 3698 , p. $886-888$.

Taylor, H. P., Jr., and Epstein, Samuel, 1962a, Relationship between $\mathrm{O}^{18} / \mathrm{O}^{16}$ in coexisting minerals of igneous and metamorphic rocks-[Part] 1, Principles and experimental results: Geol. Soc. America Bull., v. 73, no. 4, p. $461-480$. 
-1962b, Relationship between $0^{18} / 0^{16}$ ratios in coexisting minerals of igneous and metamorphic rocks[Part] 2, Application to petrologic problems: Geol. Soc. America Bull., v. 73, no. 6, p. 675-694.

Tilley, C. E., and Scoon, J. H., 1961, Differentiation of Hawaiian basalts - trends of Mauna Loa and Kilauea historic magma: Am. Jour. Sci., v. 259, no. 1, p. 60-68.

Tilling, R. I., Klepper, M. R., and Obradovich, J. D., 1968, $\mathrm{K}-\mathrm{Ar}$ ages and time span of emplacement of the Boulder batholith, Montana: Am. Jour. Sci., v. 266, no. 8, p. 671-689.

U.S. Geological Survey, 1968, Geological Survey research 1968: U.S. Geol. Survey Prof. Paper 600-A, 371 p. 1969, Geological Survey research 1969: U.S. Geol. Survey Prof. Paper 650-A, 425 p.

Viljoen, R. P., Saager, R., and Viljoen, M. J., 1969, Metallogenesis and ore control in the Steynsdorp Goldfield, Barberton Mountain Land, South Africa: Econ. Geology, v. 64, no. 7, p. 778-797.

Vincent, E. A., and Crocket, J. H., 1960a, Studies on the geochemistry of gold-[Part] I, The distribution of gold in rocks and minerals of the Skaergaard intrusion, east Greenland: Geochim. et Cosmochim. Acta, v. 18 , p. 130-142.

$-1960 \mathrm{~b}$, Studies in the geochemistry of gold-[Part] II, The gold content of some basic and ultrabasic rocks and stone meteorites: Geochim. et Cosmochim. Acta, v. 18 , p. $143-148$.
Voskresenskaya, N. T., and Zvereva, N. F., 1968, Geochemistry of gold and its distribution in the magmatic complexes of northern Kazakhstan: Geochemistry Internat., v. 5, no. 2, p. 373-381. (Translated from Geokhimiya, no. 4, p. 422-431, 1968.)

Walker, Frederick, 1940, Differentiation of the Palisade diabase, New Jersey: Geol. Soc. America Bull., v. 51, no. 7, p. 1059-1106.

Waters, A. C., 1961, Stratigraphic and lithologic variations in the Columbia River basalt: Am. Jour. Sci., v. 259, no. 8 , p. 583-611.

Weed, W. H., 1905, Economic value of hot springs and hotspring deposits: U.S. Geol. Survey Bull. 260, p. 598604.

Weissberg, D. G., 1969, Gold-silver ore-grade precipitates from New Zealand thermal waters: Econ. Geology, v. 64, p. 95-108.

White, D. E., 1955, Thermal springs and epithermal ore deposits, in Bateman, A. M., ed., Economic Geology 50th. anniversary volume, 1905-1955: Urbana, Ill., Econ. Geology Pub. Co., pt. 1, p. 99-154.

Wilson, A. D., 1964, The sampling of silicate rock powders for chemical analysis: Analyst, v. 89, no. 1054, p. 18-30.

Wright, T. L., 1964, The alkali feldspars of the Tatoosh pluton in Mount Rainier National Park: Am. Mineralogist, v. 49, p. 715-735. 
TABLES $18-44$ 
TABLE 18.-Distribution of gold in rocks of the Southern California batholith

\begin{tabular}{|c|c|c|}
\hline Sample No. & Rock type & $A u(p p b)$ \\
\hline 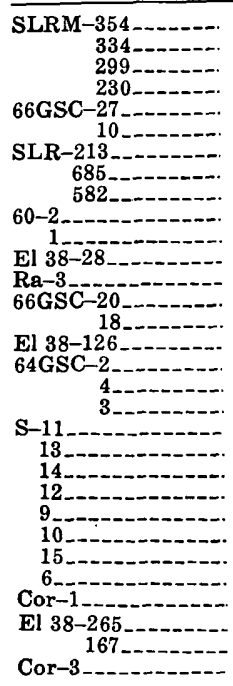 & $\begin{array}{l}\text { Olivine norite } \\
\text { Norite } \\
\text { Hornblende gabbro } \\
\text { Quartz-biotite norite } \\
\text { Gabbro } \\
\text { Green Valley Tonalite } \\
\text { Lakeview Mountain Tonalite } \\
\text { Bonsall Tonalite } \\
\text { Tonalite (sphene rich) } \\
\text { Tonalite } \\
\text { Granodiorite } \\
\text { Woodson Mountain Granodiorite } \\
\text { Woodson Mountain Granodiorite (aplite) } \\
\text { Woodson Mountain Granodiorite } \\
\text {-do do }\end{array}$ & $\begin{array}{rr}- & 0.8 \\
- & 1.5 \\
- & 11.6 \\
- & .3 \\
- & 2.7 \\
- & 10.7 \\
- & 1.1 \\
- & 1.3 \\
- & 2.5 \\
- & .8 \\
- & 3.7 \\
- & .5 \\
- & .8 \\
- & 1.2 \\
- & .6 \\
- & .5 \\
- & .3 \\
- & .5 \\
- & .3 \\
- & .3 \\
- & .4 \\
- & .3 \\
- & .3 \\
- & .2 \\
- & .3 \\
- & .5 \\
- & .5 \\
- & 1.9 \\
.6\end{array}$ \\
\hline
\end{tabular}

TABLE 19.-Distribution of gold in rocks of the Sierra Nevada, Coast Range, and Transverse Ranges, Calif. [Samples supplied by F. C. W. Dodge and D. C. Ross, U.S. Geol. Survey $]$

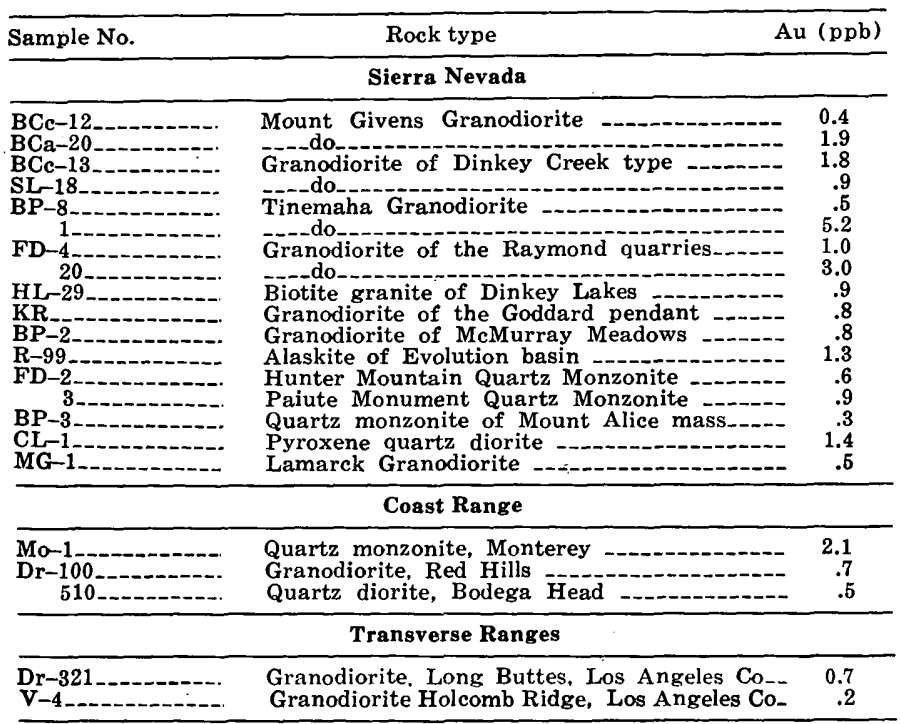

TABLE 20.-Distribution of gold in rocks of the Idaho batholith [Samples supplied by B. F. Leonard and E. S. Larsen, Jr. U.S. Geol. Survey]

\begin{tabular}{|c|c|c|}
\hline Sample No. & Rock type & $\mathrm{Au}(\mathrm{ppb})$ \\
\hline CPR-117---:--:- & Diorite & $\begin{array}{l}0.5 \\
2.6\end{array}$ \\
\hline L54-900 & Quartz diorite - & .2 \\
\hline 47L8100A- & - & $\begin{array}{l}1.5 \\
2.5\end{array}$ \\
\hline $47 \mathrm{~L} 227-$ & Porphyritic tonalite gneiss & 6.0 \\
\hline 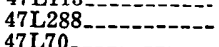 & Granodiorite - & 3.1 \\
\hline $\begin{array}{l}47 \mathrm{~L}_{2} 7 \mathrm{C}_{-} \\
\mathrm{L} 253\end{array}$ & - do do & $\begin{array}{l}3.2 \\
1.9\end{array}$ \\
\hline - & (n) & 2.8 \\
\hline L304- & 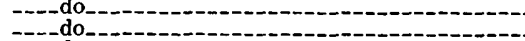 & .8 \\
\hline $\begin{array}{ll}\text { L301- } \\
\text { L295 }\end{array}$ & (n) & $\begin{array}{l}1.3 \\
5.2\end{array}$ \\
\hline L295_. & & 1.4 \\
\hline
\end{tabular}

TABLE 20.-Distribution of gold in rocks of the Idaho batholith-Continued

\begin{tabular}{|c|c|c|}
\hline Sample No. & Rock type & $(p p b)$ \\
\hline 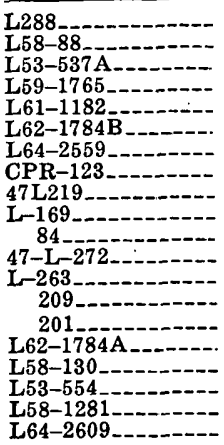 & 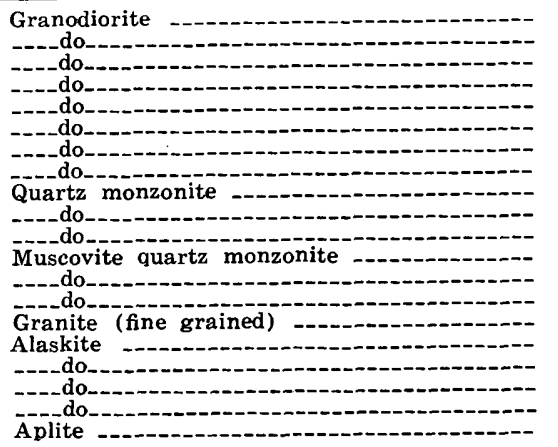 & $\begin{array}{r}3.0 \\
.6 \\
.6 \\
.3 \\
.2 \\
.1 \\
2.0 \\
.9 \\
2.7 \\
1.1 \\
1.1 \\
.6 \\
.9 \\
.4 \\
.5 \\
.3 \\
.6 \\
.2 \\
.4 \\
.8\end{array}$ \\
\hline
\end{tabular}

TABLE 21.-Distribution of gold in rocks of the Boulder batholith, Montana

\begin{tabular}{|c|c|c|}
\hline Sample No. & Rock type & $A u(p p b)$ \\
\hline 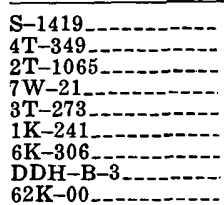 & $\begin{array}{l}\text { Syenogabbro } \\
\text { Unionville Granodiorite } \\
\text { Granodiorite of Rader Creek pluton } \\
\text { Quartz monzonite of Donald pluton } \\
\text { Clancy Granodiorite }{ }^{1} \text {. } \\
\text { Quartz monzonite of Homestake pluton } \\
\text { Butte Quartz Monzonite } \\
\text { Alaskite related to Butte Quartz Monzonite. }\end{array}$ & $\begin{array}{r}0.6 \\
3.4 \\
1.0 \\
.5 \\
2.0 \\
.5 \\
.8 \\
2.6 \\
.7\end{array}$ \\
\hline
\end{tabular}

${ }^{1}$ Clancy Granodiorite of Knopf (1957) is coextensive with the Butte Quartz Monzonite.
2 Average of 19 samples from a 4,000-ft. borehole (see table 14).

TABLE 22.-Distribution of gold in rocks of the Tatoosh pluton, Mount Rainier National Park, Wash. [Samples supplied by T. L. Wright, U.S. Geol. Survey]

\begin{tabular}{|c|c|c|}
\hline Sample No. & Rock type & (ppb) \\
\hline 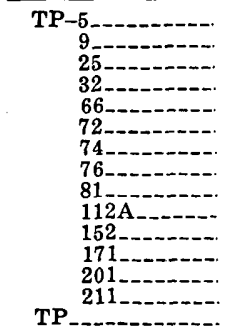 & 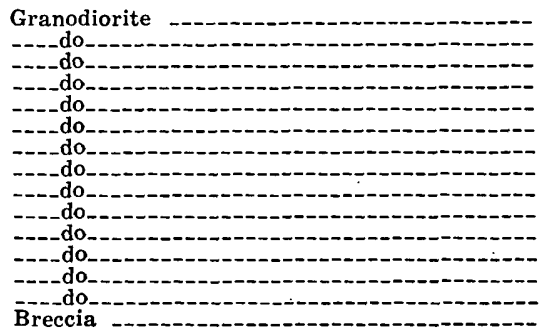 & $\begin{array}{r}0.3 \\
2.8 \\
.4 \\
3.8 \\
.8 \\
.6 \\
4.2 \\
1.4 \\
.5 \\
.7 \\
.5 \\
.9 \\
.9 \\
.6 \\
.6\end{array}$ \\
\hline
\end{tabular}

TABLE 23.-Distribution of gold in four plutonic rocks from the Rocky Mountains, Colo.

\begin{tabular}{|c|c|c|}
\hline Sample No. & Rock type and location & $(p p b)$ \\
\hline 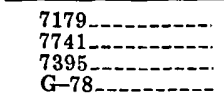 & $\begin{array}{l}\text { Quartz monzonite, Mount Princeton } \\
\text { Granite, Mount Antero } \\
\text { Quartz diorite, Mount Princeton } \\
\text { Granite, Silver Plume quarry }\end{array}$ & $\begin{array}{r}0.4 \\
.4 \\
.5 \\
.6\end{array}$ \\
\hline
\end{tabular}

TABLE 24.-Distribution of gold in plutonic rocks of the White Mountain Plutonic Series, New Hampshire [Samples supplied by A. P. Butler, U.S. Geol. Survey]

\begin{tabular}{|c|c|c|}
\hline Sample No. & Rock type & $\mathrm{Au}(\mathrm{ppb})$ \\
\hline 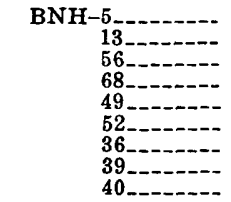 & 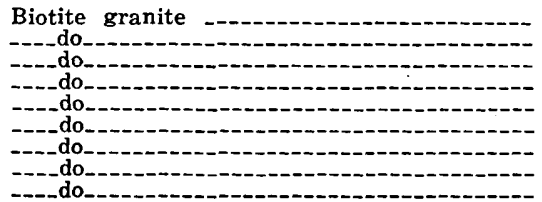 & $\begin{array}{r}0.5 \\
.9 \\
.4 \\
.3 \\
.5 \\
.5 \\
.4 \\
.8 \\
.3\end{array}$ \\
\hline
\end{tabular}


TABLE 24.-Distribution of gold in plutonic rocks of the White Mountain Plutonic Series, New Hampshire-Continued

\begin{tabular}{|c|c|c|}
\hline Sample No. & Rock type & $\mathrm{Au} \mathrm{(ppb}$ \\
\hline 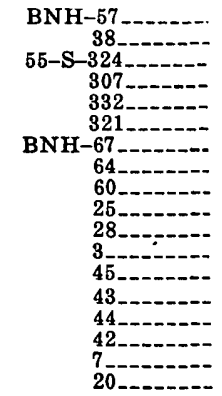 & 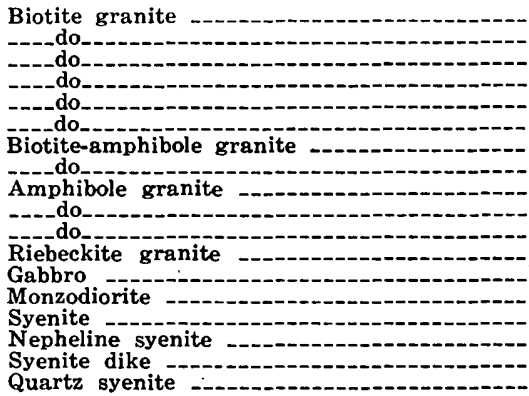 & $\begin{array}{r}0.3 \\
.2 \\
.8 \\
.5 \\
1.6 \\
1.2 \\
.3 \\
.5 \\
.4 \\
.2 \\
.8 \\
.4 \\
.3 \\
.3 \\
.3 \\
.3 \\
.4 \\
.3\end{array}$ \\
\hline
\end{tabular}

TABLE 25.-Distribution of gold in some alkalic plutonic rocks from North Carolina and South Carolina

[Samples supplied by R. E. Lemmon, Univ. of North Carolina,

\begin{tabular}{|c|c|c|}
\hline ample No. & Rock type and location & u (ppb) \\
\hline A-3---- & $\begin{array}{l}\text { Quartz monzonite, Salisbury pluton, } \\
\text { Rowan County, N.C. }\end{array}$ & 0.7 \\
\hline $\begin{array}{l}69 \mathrm{G}-9 \mathrm{a}-------\cdot \\
9 \mathrm{~b}\end{array}$ & 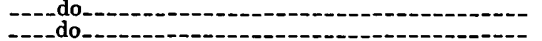 & .2 \\
\hline A-2 - & $\begin{array}{l}-4 \\
-10\end{array}$ & 1.0 \\
\hline 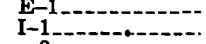 & - & $\begin{array}{l}1.4 \\
1.8\end{array}$ \\
\hline $69 \mathrm{~g}-11 \mathrm{a}-\cdots$ & do- & 1.2 \\
\hline G-4 & - & 2.3 \\
\hline 69G-11b-------- & --_do-_- & .2 \\
\hline $8=-$ & Granite, Pageland & .2 \\
\hline & $\begin{array}{l}\text { Gabbro, Concord quadrangle. North Carolina } \\
\text { Syenite. Concord quadrangle, North Carolina }\end{array}$ & .2 \\
\hline
\end{tabular}

TABLE 26.-Distribution of gold in volcanic rocks from Hawaii

[Samples supplied by H. A. Powers, T. L. Wright, and A. T. Anderson, U.S. Geol. Survey]

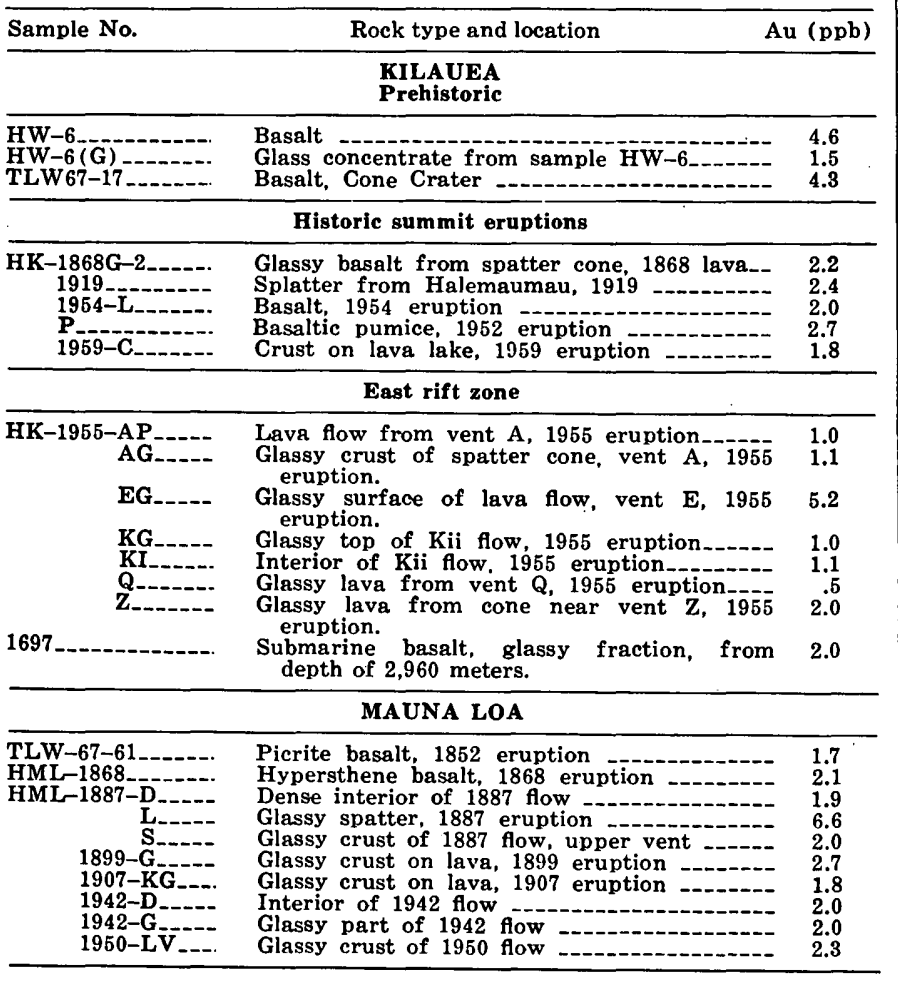

TABLE 26.-Distribution of gold in volcanic rocks from Hawaii-Continued

\begin{tabular}{|c|c|c|}
\hline Sample No. & Rock type and location & $(\mathrm{ppb})$ \\
\hline \multicolumn{3}{|c|}{ HALEAKA LA } \\
\hline 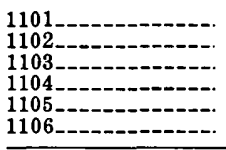 & 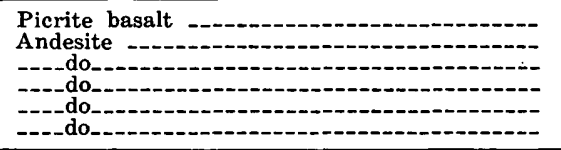 & $\begin{array}{r}0.2 \\
.8 \\
.5 \\
1.3 \\
3.9 \\
.8\end{array}$ \\
\hline \multicolumn{3}{|c|}{ HONOLULU VOLCANIC SERIES } \\
\hline 10401 & Nepheline melilite basalt & 1.4 \\
\hline \multicolumn{3}{|c|}{ KOOLAU VOLCANIC SERIES } \\
\hline 10403 & Nonporphyritic basalt -- & 1.4 \\
\hline
\end{tabular}

TABLE 27.-Distribution of gold and copper in volcanic rocks from the Mid-Atlantic Ridge and East Pacific Rise

[Samples supplied by A. E. J. Engel, A. T. Myers, and David Gottfried, U.S. Geol. Survey, and W. G. Melson, Smithsonian Inst.]

\begin{tabular}{|c|c|c|c|}
\hline Sample No. & Rock type & $\underset{(\mathrm{ppm})^{1}}{\mathrm{Cu}}$ & $\underset{(\mathbf{p p b})}{\mathrm{Au}}$ \\
\hline \multicolumn{4}{|c|}{ MID-ATLANTIC RIDGE } \\
\hline $\begin{array}{l}\text { AD-2 } \\
\text { AD5-18 } \\
\text { AD-4 }\end{array}$ & $\begin{array}{l}\text { Tholeiite } \\
-- \text { do }\end{array}$ & $\begin{array}{l}66 \\
81 \\
75\end{array}$ & $\begin{array}{r}0.6 \\
1.6 \\
.5 \\
\end{array}$ \\
\hline \multicolumn{4}{|c|}{ EAST PACIFIC RISE } \\
\hline 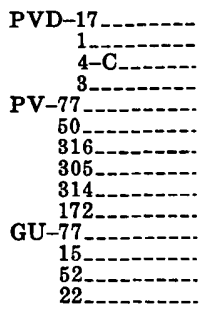 & 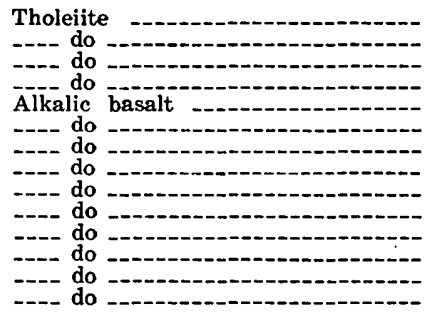 & $\begin{array}{l}75 \\
64 \\
87 \\
80 \\
42 \\
56 \\
48 \\
20 \\
34 \\
37 \\
10 \\
15 \\
38 \\
58\end{array}$ & $\begin{array}{r}1.0 \\
1.8 \\
1.0 \\
2.0 \\
1.2 \\
.8 \\
1.8 \\
.9 \\
.9 \\
1.0 \\
.3 \\
.3 \\
.2 \\
.4\end{array}$ \\
\hline
\end{tabular}

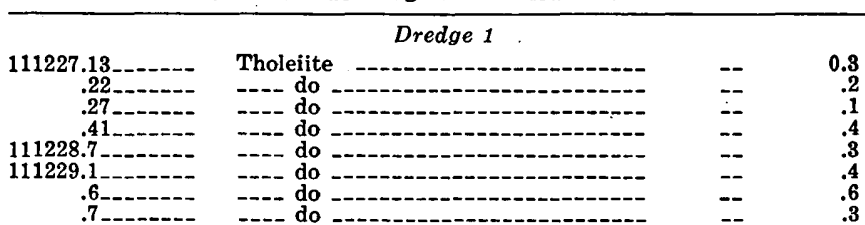

Dredge 2

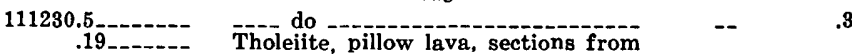

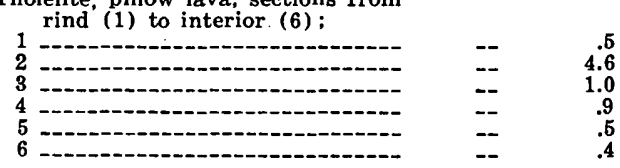

111233.1

Dredge $s$

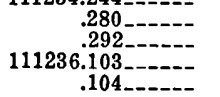

Tholeiite

Dredge 5

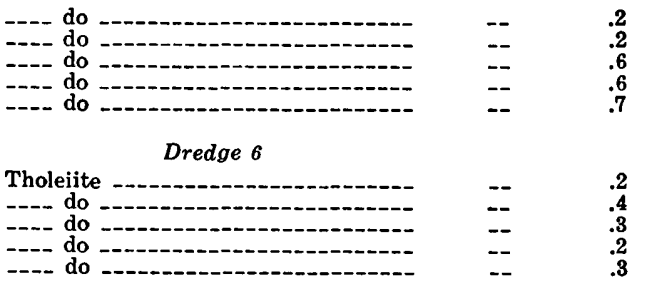

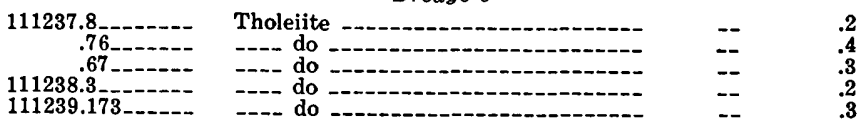

Dredge 10

DR-10R -.-.-. Glassy rind of tholeiitic basalt_.-. - $\quad .2$ 
TABLE 27.-Distribution of gold and copper in volcanic rocks from the Mid-Atlantic Ridge and East Pacific Rise-Continued

\begin{tabular}{|c|c|c|c|}
\hline Sample No. & Rock type & $\underset{(\mathbf{p p m})^{1}}{\mathbf{C u}}$ & $\underset{(\mathrm{ppb})}{\mathrm{Au}}$ \\
\hline & Dredge 11 & & \\
\hline \multirow[t]{2}{*}{111243.5} & Tholeiite --1-- & -- & 0.5 \\
\hline & Dredge 12 & & \\
\hline \multirow[t]{2}{*}{$\begin{array}{r}111244.10 \\
.15 \\
.\end{array}$} & Tholeiite - do & 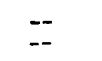 & .4 \\
\hline & Dredge 13 & & \\
\hline 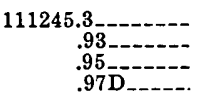 & 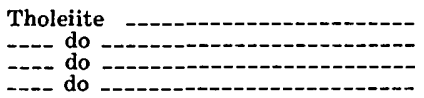 & $\begin{array}{l}-- \\
-- \\
--\end{array}$ & $\begin{array}{l}.5 \\
.4 \\
.3 \\
.1\end{array}$ \\
\hline
\end{tabular}

${ }^{1}$ R. G. Havens, analyst (Engel and others, 1965).

TABLE 28.-Distribution of gold in plateau basalts and other volcanic rocks, Oregon and Washington

[Samples supplied by T. P. Thayer, U.S. Geol. Survey, and A. C. Waters] Sample No. Location

$\mathrm{Au}(\mathrm{ppb})$

BASALTS OF THE COLUMBIA RIVER GROUP Picture Gorge Basalt

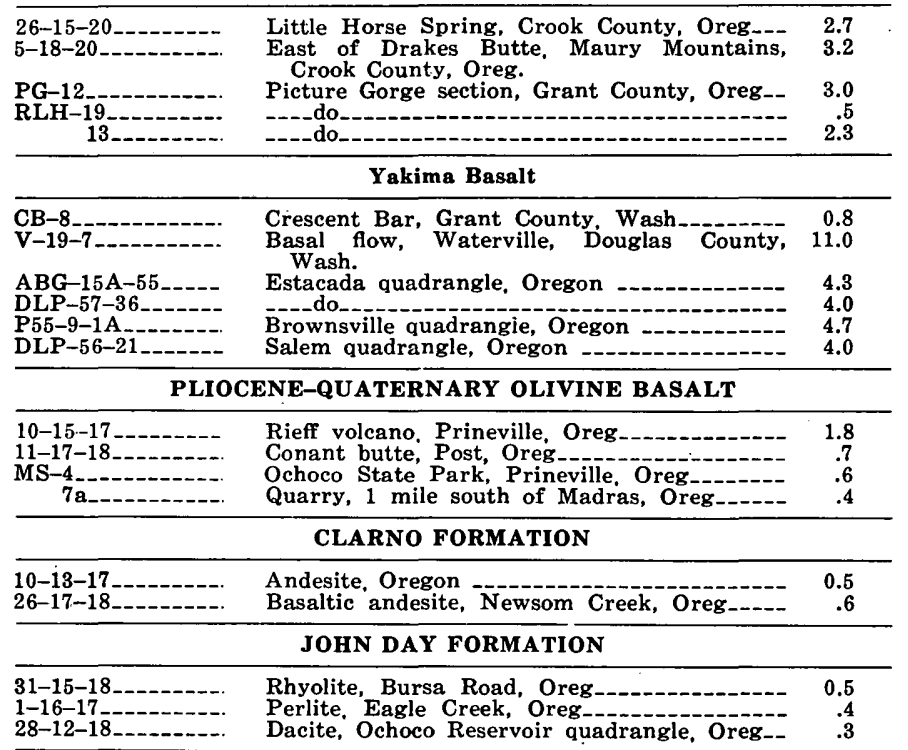

TABLE 29.-Distribution of gold in basalts of the Snake River Group and associated rhyolitic rocks, Idaho

[Samples supplied by H. A. Powers, U.S. Geol. Survey]

\begin{tabular}{|c|c|c|c|}
\hline Sample No. & Rock type & Location & $\underset{(\mathrm{ppb})}{\mathrm{Au}}$ \\
\hline \multicolumn{4}{|c|}{ Basalts } \\
\hline 54P-3 & Basalt _- & Near Tuana gulch. & 0.9 \\
\hline 4 & --.-do_-..--.-- & Clear Lake Springs -. & .2 \\
\hline 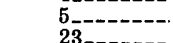 & - do & Near Buhl & 1.3 \\
\hline $55 \mathrm{P}-42=-$ & - & Thousand Springs & 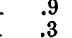 \\
\hline $54 \mathrm{P}-68 \mathrm{n}$ & Olivine basalt & Wendell - & .2 \\
\hline 65 & - & $\begin{array}{l}\text { Near } \\
\text { Sand Springs ranch }\end{array}$ & \\
\hline $55 \mathrm{P}-275$ & - do & Malad Spring & .6 \\
\hline 235 & - & Near Owsley Bridge. & .0 \\
\hline $236-\cdots$ & plodo & -.-do_o & 1.1 \\
\hline WJC167-58 & $\begin{array}{l}\text { Plagioclase basalt_-- } \\
\text { Olivine basalt }\end{array}$ & Ämerican Falls powerhouse & $\begin{array}{l}.2 \\
.4\end{array}$ \\
\hline WJC148-58_-. & - - do do & $\begin{array}{l}\text { Near Rockland } \\
\text { Alkal }\end{array}$ & .4 \\
\hline OB9-57------ & Basalt & Clover Creek - & .3 \\
\hline $\begin{array}{l}\text { PV 67-57----- } \\
\text { OB32-57---- }\end{array}$ & Alkaline basalt & King $\mathrm{Hill}^{-}$ & .2 \\
\hline $\mathrm{CP} 40-57$ & _... do & -.-do do... & .2 \\
\hline
\end{tabular}

TABLE 29.-Distribution of gold in basalts of the Snake River Group and associated rhyolitic rocks, Idaho-Continued

\begin{tabular}{|c|c|c|c|}
\hline Sample No. & Rock type & Location & $\underset{(\mathbf{p p b})}{\mathbf{A u}}$ \\
\hline \multicolumn{4}{|c|}{ Rhyolites } \\
\hline 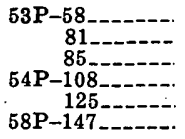 & $\begin{array}{l}\text { Porphyritic rhyolite } \\
\text { Obsidian tuff. } \\
\text { Rhyolite tuff. } \\
\text { Pumice scoria }\end{array}$ & $\begin{array}{l}\text { Elmore County } \\
\text { Twin Falls County. } \\
\text { South of Murphy } \\
\text { West of Oakley } \\
\text { West of Carey }\end{array}$ & $\begin{array}{r}0.6 \\
.2 \\
.2 \\
.4 \\
1.2 \\
1.1\end{array}$ \\
\hline
\end{tabular}

TABLE 30.-Distribution of gold and copper in the Greenstone Flow (1,300 feet thick) of the Michigan copper district [Samples supplied by H. R. Cornwall, U.S. Geol. Survey]

\begin{tabular}{|c|c|c|c|c|}
\hline Sample No. & $\begin{array}{l}\text { Depth, } \\
\text { in feet, } \\
\text { below } \\
\text { surface } \\
\text { of flow }\end{array}$ & Rock type & $\underset{(\mathrm{ppm})^{1}}{\mathrm{Cu}}$ & $\underset{(\mathbf{p p b})}{\mathrm{Au}}$ \\
\hline 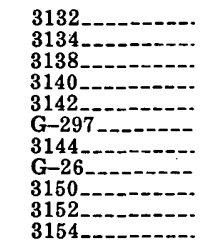 & $\begin{array}{r}118 \\
215 \\
315 \\
245 \\
387 \\
422 \\
501 \\
800 \\
941 \\
1,085 \\
1,228\end{array}$ & $\begin{array}{l}\text { Basalt } \\
\text { Pegmatite } \\
\text { Basalt } \\
\text { Pegmatite } \\
\text { Basalt } \\
\text { Granophyre } \\
\text { Basalt } \\
\text {-do } \\
\text { do do }\end{array}$ & $\begin{array}{r}90 \\
100 \\
83 \\
210 \\
110 \\
100 \\
110 \\
60 \\
72 \\
80 \\
110\end{array}$ & $\begin{array}{r}1.4 \\
14.4 \\
3.9 \\
3.5 \\
2.9 \\
7.6 \\
2.9 \\
8.5 \\
5.5 \\
1.8 \\
7.0\end{array}$ \\
\hline
\end{tabular}

${ }^{1}$ K. J. Murata, analyst (Cornwall and Rose, 1957).

TABLE 31.-Distribution of gold in basalt and diabase from the Triassic basin, Eastern United States

\begin{tabular}{cccc}
\hline $\begin{array}{c}\text { Sample } \\
\text { No. }\end{array}$ & Rock & Location & $\begin{array}{c}\mathbf{A u} \\
(\mathbf{p p b})\end{array}$ \\
\hline Connecticat &
\end{tabular}

[Samples supplied by P. M. Hanshaw and C. E. Fritts,

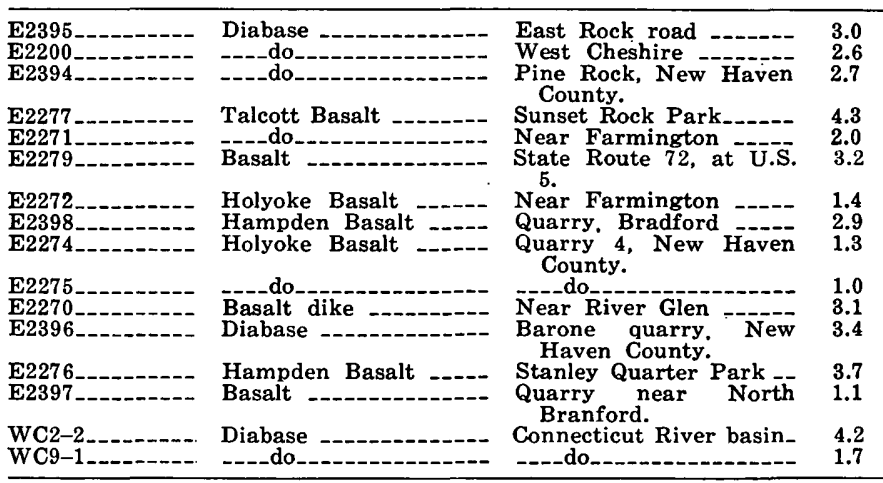

New Jersey
[Samples supplied by G. T. Faust, U.S. Geol. Survey]

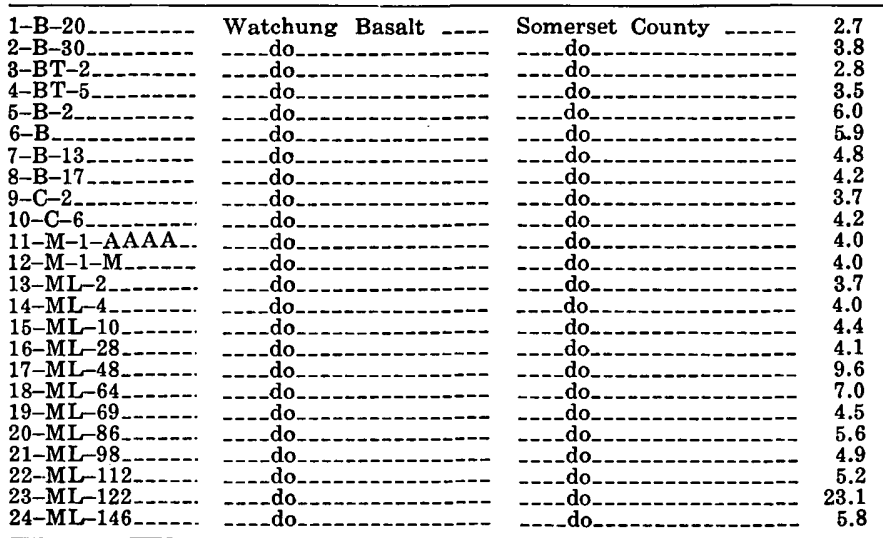


TABLE 31.-Distribution of gold in basalt and diabase from the Triassic basin, Eastern United States-Continued

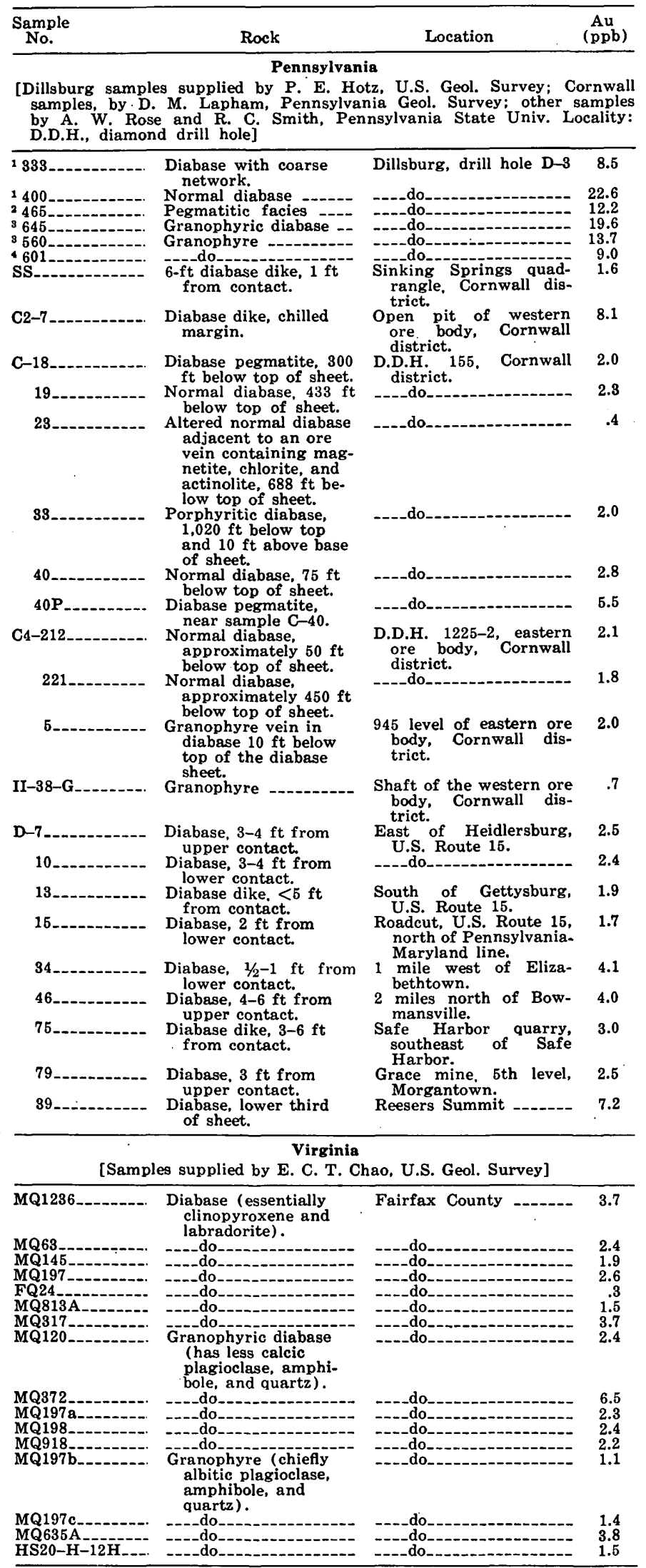

TABLE 31.-Distribution of gold in basalt and diabase from the Triassic basin, Eastern United States-Continued

\begin{tabular}{llll}
$\begin{array}{l}\text { Sample } \\
\text { No. }\end{array}$ & Rock & Location & $\begin{array}{c}\text { Au } \\
(\mathbf{p p b}\end{array}$ \\
\hline
\end{tabular}

[Samples supplied by P. C. Ragland, Univ. of North Carolina]

\begin{tabular}{|c|c|c|c|}
\hline BP-1_-_-:--.-- & $\begin{array}{l}\text { 107-ft low } \mathrm{K}_{2} \mathrm{O} \text { diabase } \\
\text { dike, } 1 \mathrm{ft} \text { from } \\
\text { contact. }\end{array}$ & Deep River basin ---.- & 4.5 \\
\hline D8R-1 & $\begin{array}{l}\text { 47-ft low } \mathrm{K}_{2} \mathrm{O} \text { diabase } \\
\text { dike, } 3 \mathrm{ft} \text { from } \\
\text { contact. }\end{array}$ & 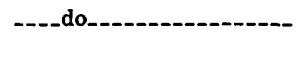 & 6.9 \\
\hline Du6-1_----.---- & $\begin{array}{l}\text { 6-ft low } \mathrm{K}_{2} \mathrm{O} \text { diabase } \\
\text { dike. } 0.5 \mathrm{ft} \text { from } \\
\text { contset. }\end{array}$ & 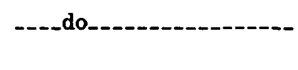 & 3.6 \\
\hline JY-1_-_........-- & $\sim 60-\mathrm{ft}$ diabase dike, & ---_do-------. & 3.8 \\
\hline NC30-1 & $\begin{array}{l}\sim_{\text {diabase dike, }}, 1 \mathrm{ft} \\
\text { from contact. }\end{array}$ & --.-_do----. & 7.9 \\
\hline RD-1 & $10-\mathrm{ft}$ low $\mathrm{K}_{2} \mathrm{O}$ diabase & 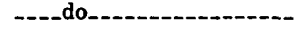 & 2.7 \\
\hline RS-1_-_-_-_-_..- & $\begin{array}{l}\text { 9-ft low } \mathrm{K}_{2} \mathrm{O} \text { diabase } \\
\text { dike, } 0.5 \mathrm{ft} \text { from } \\
\text { contact. }\end{array}$ & -...-do_-.-- & 3.2 \\
\hline
\end{tabular}

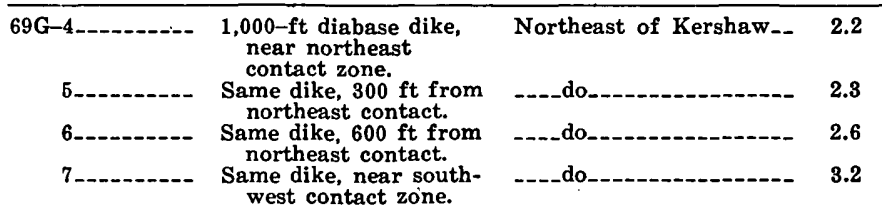

\section{Copper value is $150 \mathrm{ppm}$. \\ Copper value is $200 \mathrm{ppm}$. \\ 4 Copper value is $400 \mathrm{ppm}$.}

TABLE 32.-Distribution of gold in Precambrian diabase intrusions, Iron County, Mo.

[Samples supplied by G. A. Desborough, U.S. Geol. Survey. Altered samples indicated by an asterisk $\left.\left({ }^{*}\right)\right]$

\begin{tabular}{|c|c|c|c|c|}
\hline \multicolumn{2}{|c|}{ Shepherd Mountain intrusion } & \multicolumn{3}{|c|}{160 -foot sill } \\
\hline Sample depth & $\underset{(\mathbf{p p b})}{\mathrm{Au}}$ & $\begin{array}{l}\text { Sample } \\
\text { No. }\end{array}$ & $\begin{array}{l}\text { Feet above } \\
\text { base of sill }\end{array}$ & $\underset{(\mathrm{ppb})}{\mathrm{Au}}$ \\
\hline $\begin{array}{l}1,715^{*} \\
1,760 \\
1,775 \\
1,790 \\
1,810 \\
1,822 \\
1,845 \\
1,862 \\
1,876 \\
1,923 \\
1,943 \\
1,970 \\
2,009\end{array}$ & $\begin{array}{l}0.5 \\
1.2 \\
1.4 \\
1.6 \\
1.8 \\
5.7 \\
2.2 \\
2.0 \\
1.5 \\
3.5 \\
3.1 \\
1.9 \\
2.6\end{array}$ & $\begin{array}{c}2 \\
3^{*} \\
5 \\
6^{*} \\
8^{*} \\
9 \\
10 \\
12 \\
15^{*} \\
16^{*} \\
17 \\
18\end{array}$ & $\begin{array}{c}5 \\
7 \\
42 \\
441 / 2 \\
50 \\
8911 / 2 \\
100 \\
118 \\
140 \\
143 \\
146 \\
154\end{array}$ & $\begin{array}{l}7.4 \\
.5 \\
3.1 \\
2.2 \\
3.2 \\
1.7 \\
3.3 \\
3.8 \\
.8 \\
1.2 \\
.6 \\
.7\end{array}$ \\
\hline
\end{tabular}

TABLE 33.-Distribution of gold and copper in the Great Lake intrusion, Tasmania

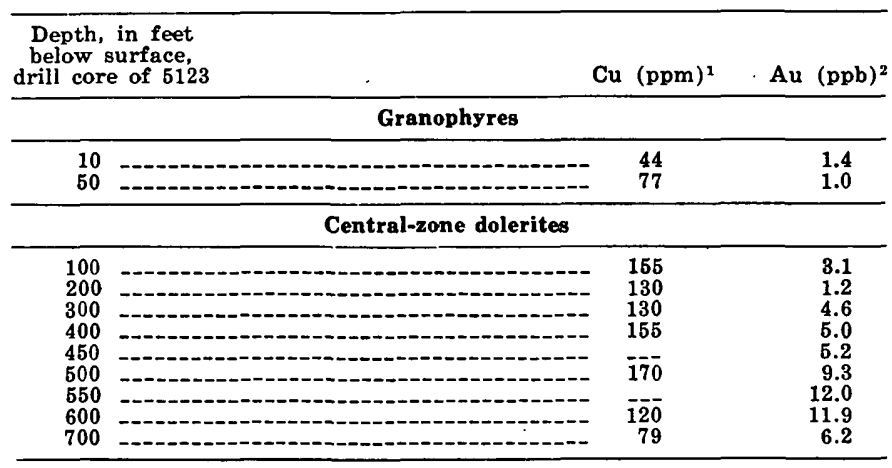


TABLE 33.-Distribution of gold and copper in the Great Lake intrusion, Tasmania-Continued

\begin{tabular}{|c|c|c|c|}
\hline $\begin{array}{l}\text { Depth, in feet } \\
\text { below surface, } \\
\text { drill core of } 5123\end{array}$ & & $(\mathrm{ppm})^{1}$ & $(\mathrm{ppb})^{2}$ \\
\hline \multicolumn{4}{|c|}{ Lower zone dolerites } \\
\hline 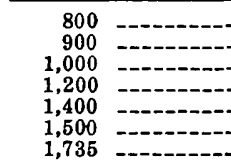 & 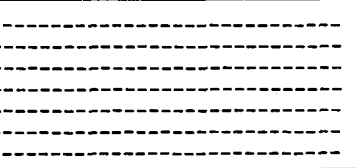 & $\begin{array}{l}93 \\
60 \\
49 \\
42 \\
37 \\
44 \\
48\end{array}$ & $\begin{array}{l}4.2 \\
3.4 \\
4.1 \\
3.5 \\
2.7 \\
2.4 \\
5.2\end{array}$ \\
\hline \multicolumn{4}{|c|}{ Chilled margin } \\
\hline------- & 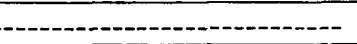 & 75 & 7.3 \\
\hline \multicolumn{4}{|c|}{$\begin{array}{l}1 \text { Data from Greenland and Lovering (1966). } \\
2 \text { Data from Rowe (1969). } \\
{ }^{2} \text { Sample is from } 1 \text { foot above lower contact of drill core } 5084 .\end{array}$} \\
\hline \multicolumn{4}{|c|}{$\begin{array}{c}\text { TABLE 34.-Distribution of gold in volcanic rocks of the } \\
\text { Western Cascades, Oreg. } \\
\text { [Samples supplied by D. L. Peck, U.S. Geol. Survey] }\end{array}$} \\
\hline Sample No. & Rock type & & $\mathrm{du}(\mathrm{ppb})$ \\
\hline \multicolumn{4}{|c|}{ Little Butte Volcanic Series (Oligocene and Miocene) } \\
\hline 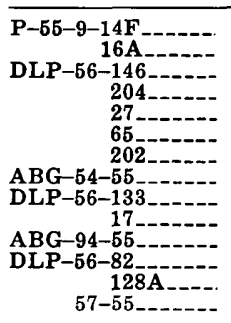 & 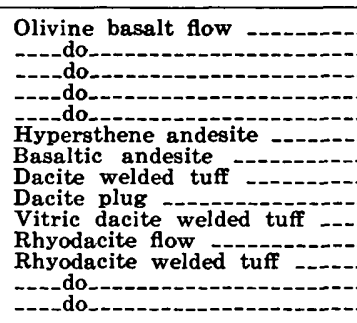 & $\begin{array}{l}\mathrm{u} \\
\mathrm{y}\end{array}$ & $\begin{array}{r}5.3 \\
3.3 \\
5.0 \\
4.8 \\
2.8 \\
10.7 \\
3.8 \\
1.1 \\
1.1 \\
.6 \\
.8 \\
1.1 \\
.9 \\
1.4\end{array}$ \\
\hline \multicolumn{4}{|c|}{ Sardine Formation (lower and middle Miocene) } \\
\hline 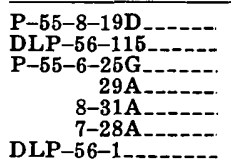 & $\begin{array}{l}\text { Basaltic andesite } \\
\text { Olivine andesite } \\
\text { Hypersthene andesite } \\
\text { Labro do } \\
\text { Hyperste andesite } \\
\text { Andesitic tuff andesite }\end{array}$ & 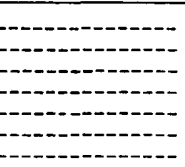 & $\begin{array}{r}1.5 \\
.8 \\
1.0 \\
.6 \\
1.1 \\
7.0 \\
11.0\end{array}$ \\
\hline
\end{tabular}

TABLE 35.-Distribution of gold in volcanic rocks of the Southern High Cascades, Calif., and vicinity

[Samples supplied by A. L. Smith and I. S. E. Carmichael, Univ. of California, and A. T. Anderson and David Gottfried, U.S. Geol. Survey]

\begin{tabular}{|c|c|c|}
\hline Sample No. & Rock type & $A u(p p b)$ \\
\hline \multicolumn{3}{|c|}{ Mount Shasta } \\
\hline 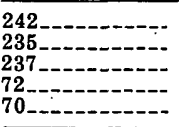 & $\begin{array}{l}\text { Olivine basalt, cinder cone } \\
\text { Pyroxene andesite }\end{array}$ & $\begin{array}{r}11.6 \\
6.6 \\
4.3 \\
12.0 \\
9.1\end{array}$ \\
\hline \multicolumn{3}{|c|}{ Medicine Lake Highland } \\
\hline 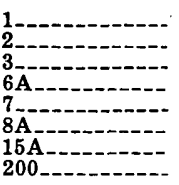 & 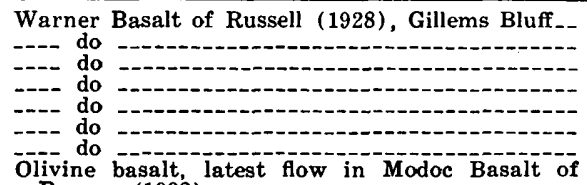 & $\begin{array}{l}3.5 \\
1.9 \\
3.3 \\
2.2 \\
4.9 \\
6.2 \\
2.5 \\
2.2\end{array}$ \\
\hline 187-_-----_-_-. & $\begin{array}{l}\text { Powers (1932) } \\
\text { Olivine basalt, Paint Pot Crater Flow of Ander- } \\
\text { son (1941). }\end{array}$ & .8 \\
\hline $\begin{array}{l}\text { GM } \\
\text { GM-P } \\
\text { LGM } \\
\text { LGM-P }\end{array}$ & $\begin{array}{l}\text { son (1941). } \\
\text { Basaltic andesite, Schonchin flow } \\
\text { Rhyolitic obsidian, G'ass Mountain } \\
\text { Rhyolitic pumice, Glass Mountain } \\
\text { Rhyolitic obsidian, Little Glass Mountain } \\
\text { Rhyolitic pumice, Little Glass Mountain }\end{array}$ & $\begin{array}{r}.0 \\
4.7 \\
.5 \\
.4 \\
.5\end{array}$ \\
\hline \multicolumn{3}{|c|}{ Lassen area } \\
\hline Cal 20_-..---- & $\begin{array}{l}\text { Quartz basalt, near vent of } 1851 \text { flow, Cinder } \\
\text { Cone, Lassen National Park. }\end{array}$ & 1.5 \\
\hline Cal 24_------ & $\begin{array}{l}\text { Quartz basalt, Cinder Cone, Lassen National } \\
\text { Park. }\end{array}$ & 14.1 \\
\hline Cal 25_-_----- & $\begin{array}{l}\text { Quartz basalt, pre-1851 flow near Butte Lake, } \\
\text { Cinder Cone, Lassen National Park. }\end{array}$ & 19.4 \\
\hline
\end{tabular}

TABLE 35.-Distribution of gold in volcanic rocks of the Southern High Cascades, Calif., and vicinity-Continued

\begin{tabular}{|c|c|c|}
\hline Sample No. & Rock type & $\mathrm{u} \quad(\mathrm{ppb})$ \\
\hline \multicolumn{3}{|c|}{ Lassen area-Continued } \\
\hline Cal $43-1-1-1--$ & $\begin{array}{l}\text { Quartz basalt, recent flow, West Prospect Peak, } \\
\text { Lassen National Park. } \\
\text { Basaltic andesite, Red Lake Mountain } \\
\text { Olivine basalt, Hat Creek Basalt of Anderson } \\
\text { (1940). }\end{array}$ & $\begin{array}{r}12.7 \\
7.0 \\
4.6\end{array}$ \\
\hline \multicolumn{3}{|c|}{$\begin{array}{c}\text { TABLE 36.-Distribution of gold in some rhyolites from } \\
\text { Mono County, Calif. } \\
\text { [Samples supplied by Irving Friedman, U.s. Geol. Survey] }\end{array}$} \\
\hline Sample No. & Rock type & $\mathrm{Au}(\mathrm{ppb})$ \\
\hline 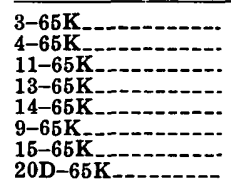 & 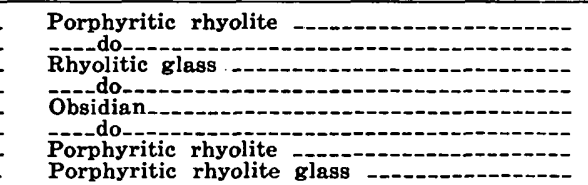 & $\begin{array}{r}0.4 \\
.1 \\
1.9 \\
.5 \\
.3 \\
.2 \\
.2 \\
.1\end{array}$ \\
\hline
\end{tabular}

TABLE 37.-Distribution of gold in volcanic rocks of the Jemez Mountains, N. Mex.

[Samples supplied by R. L. Smith, R. A. Bailey, and David Gottfried, U.S. Geol. Survey]

\begin{tabular}{|c|c|c|}
\hline Sample No. & Rock type and age or location & $\mathrm{Au}(\mathrm{ppb})$ \\
\hline \multicolumn{3}{|c|}{ BASALTIC ROCKS } \\
\hline 52-1571---.------ & Basalt, Pliocene - & \\
\hline 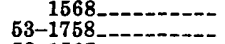 & - & $\begin{array}{l}3.9 \\
6.1\end{array}$ \\
\hline 50 & Olivine basalt, Pliocene & 2.9 \\
\hline$-\cdots$ & - & \\
\hline A-59- & do- & 1.8 \\
\hline- & 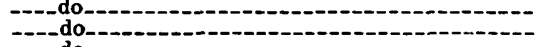 & $\begin{array}{l}2.5 \\
1.7\end{array}$ \\
\hline- & ölivine basalt, Pliocene-Pleistocene - & $\begin{array}{l}1.3 \\
2.2\end{array}$ \\
\hline - n & - & 1.9 \\
\hline
\end{tabular}

PRECALDERA SILICIC VOLCANICS

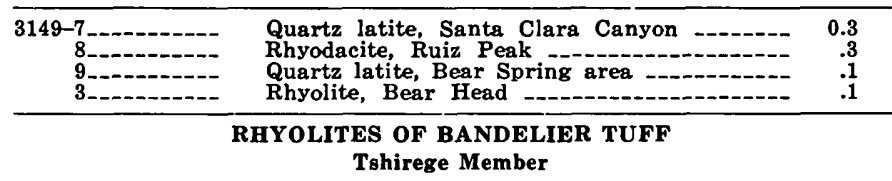

\begin{tabular}{|c|c|c|}
\hline 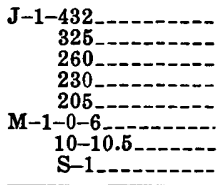 & $\begin{array}{l}\text { Ash flow, } 230 \mathrm{ft} \text { above base } \\
\text { Ash flow, } 120 \mathrm{ft} \text { above base } \\
\text { Ash flow, } 55 \mathrm{ft} \text { above base } \\
\text { Ash flow, } 25 \text { ft above base } \\
\text { Air-fall pumice from base of section } \\
\text { Air-fall pumice }\end{array}$ & $\begin{array}{r}1.6 \\
1.0 \\
.5 \\
1.0 \\
.9 \\
.7 \\
1.0 \\
.7\end{array}$ \\
\hline & lember & \\
\hline
\end{tabular}

\begin{tabular}{|c|c|c|}
\hline 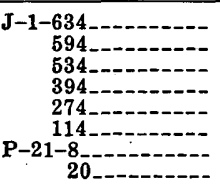 & $\begin{array}{l}\text { Ash flow, } 520 \mathrm{ft} \text { above base } \\
\text { Ash flow, } 480 \mathrm{ft} \text { above base } \\
\text { Ash flow, } 420 \mathrm{ft} \text { above base } \\
\text { Ash flow, } 280 \mathrm{ft} \text { above base } \\
\text { Pumice, } 160 \mathrm{ft} \text { above base } \\
\text { Pumice from base of seetion } \\
\text { Air-fall pumice }\end{array}$ & $\begin{array}{r}0.4 \\
.7 \\
.7 \\
.5 \\
.6 \\
.4 \\
.7 \\
.6\end{array}$ \\
\hline \multicolumn{3}{|c|}{ POSTCALDERA SILICIC VOLCANICS } \\
\hline
\end{tabular}

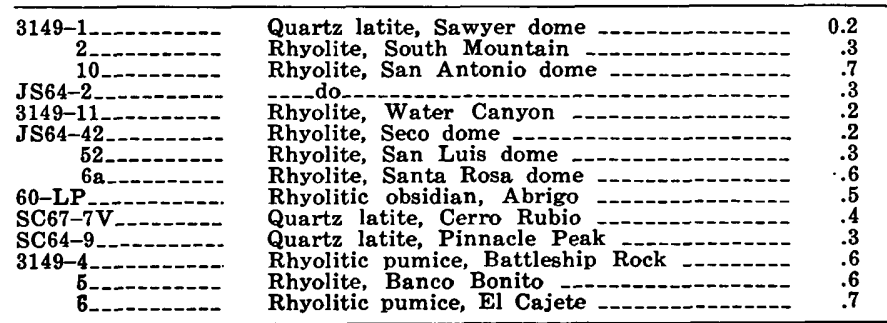


TABLE 38.-Distribution of gold in volcanic rocks from Yellowstone National Park, Wyo., and vicinity

[Samples supplied by L. P. Muffler, Warren Hamilton, and David Gottfried, U.S. Geol. Survey]

\begin{tabular}{|c|c|c|}
\hline Sample No. & Rock type and location & $A u(p p b)$ \\
\hline 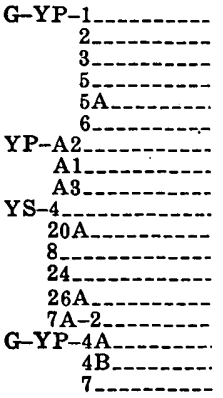 & $\begin{array}{l}\text { Rhyolite, Firehole Falls } \\
\text { Rhyolite, Midway Geyser basin } \\
\text { Obsidian, Obsidian Cliff } \\
\text { Rhyolite tuff, Golden Gate Canyon } \\
\text { Rhyolite tuff, below sample G-YP-5 } \\
\text { Rhyolite tuff, Wraith Falls } \\
\text { Rhyolite tuff. Mount Everts } \\
\text { Obsidian, Reas Pass } \\
\text { Perlite, Midway Geyser basin } \\
\text { Rhyolite tuff, Cougar Creek } \\
\text { Rhyolite tuff, West Yellowstone } \\
\text { Rhyolite, West Yellowstone } \\
\text { Obsidian, West Yellowstone } \\
\text { Basalt, Sheepeater Cliffs } \\
\text { Basalt, Undine Falls }\end{array}$ & $\begin{array}{r}0.1 \\
.1 \\
.2 \\
.3 \\
.8 \\
.2 \\
.4 \\
.4 \\
.2 \\
1.3 \\
.4 \\
.5 \\
.4 \\
1.0 \\
1.5 \\
.2 \\
.2 \\
.2\end{array}$ \\
\hline
\end{tabular}

TABLE 39.-Distribution of gold in metamorphosed Precambrian silicic volcanic rocks in central A rizona [Samples supplied by C. A. Anderson, U.S. Geol. Survey]

\begin{tabular}{|c|c|c|}
\hline Sample No. & Rock type & $\mathrm{Au}(\mathrm{ppb})$ \\
\hline \multicolumn{3}{|c|}{ Ash Creek Group } \\
\hline $\begin{array}{l}1 \\
2 \\
4 \\
5 \\
7 \\
8 \\
\end{array}$ & $\begin{array}{l}\text { Deception rhyolite } \\
\text { Buzzard rhyolite (chloritized) } \\
\text { Deception rhyolite } \\
\text { - do do - }\end{array}$ & 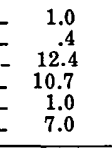 \\
\hline \multicolumn{3}{|c|}{ Alder Group } \\
\hline $\begin{array}{l}11 \\
12 \\
13 \\
14 \\
15 \\
16 \\
17 \\
18 \\
19\end{array}$ & $\begin{array}{l}\text { Rhyolite, Green Gulch Volcanics }{ }^{1} \\
\text { Rhyolitic tuff, Spud Mountain Volcanics } \\
\text { Rhyolite tuff, Texas Gulch Formation }{ }^{1} \\
\text { Rhyolite, Iron King Volcanics }{ }^{1} \\
\text { Rhyolitic tuff } \\
\text { Rhyolite, Spud Mountain Volcanics } \\
\text { Intrusive rhyolite, Spud Mountain Volcanics }\end{array}$ & $\begin{array}{r}0.9 \\
.2 \\
.2 \\
.2 \\
.2 \\
.5 \\
.2 \\
.2 \\
8.3 \\
3.4\end{array}$ \\
\hline \multicolumn{3}{|c|}{ Quartz porphyry } \\
\hline $\begin{array}{c}\text { II } \\
\text { III } \\
\text { V } \\
\text { VI }\end{array}$ & $\begin{array}{l}\text { Quartz porphyry } \\
\text { Quartz porphyry (foliated) }\end{array}$ & $\begin{array}{r}7.4 \\
1.0 \\
1.9 \\
3.6 \\
.5\end{array}$ \\
\hline
\end{tabular}

1 Formerly considered to be in Alder Group.

TABLE 40.-Distribution of gold in volcanic rocks from the Beatty area, Nevada

[Samples supplied by H. R. Cornwall, U.S. Geol. Survey]

\begin{tabular}{|c|c|c|}
\hline Sample No. & Rock type & $\mathrm{Au}(\mathrm{ppb})$ \\
\hline \multicolumn{3}{|c|}{ Bullfrog Hills caldera } \\
\hline 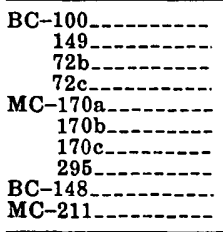 & $\begin{array}{l}\text { Lithoidal welded tuff } \\
\text { Basal glass zone of rhyolite flow } \\
\text { Felsitic zone of rhyolite flow BC- } 72 \mathrm{~b} \\
\text { Zeolitized tuff } \\
\text { Basal glass zone of flow } \\
\text { Felsitic zone of rhyolite flow MC-170b } \\
\text { Glass zone of rhyolite flow or intrusive } \\
\text { Porphyritic latite flow } \\
\text { Basalt flow }\end{array}$ & $\begin{array}{r}0.5 \\
.2 \\
.2 \\
.3 \\
22.0 \\
2.0 \\
9.2 \\
.9 \\
.5 \\
1.8\end{array}$ \\
\hline \multicolumn{3}{|c|}{ Yucca Mountains caldera } \\
\hline 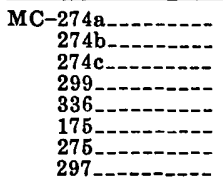 & $\begin{array}{l}\text { Zeolitized basal tuff of welded tuff } \\
\text { Basal glass zone of welded tuff } \\
\text { Lithoidal welded tuff } \\
\text { Basal glass zone of welded tuff } \\
\text { Glassy zone of intrusive rhyolite } \\
\text { Rhyolite stock } \\
\text { Rhyodacite dike, upper Tertiary (?) } \\
\text { Recent basalt flow }\end{array}$ & $\begin{array}{r}1.1 \\
3.4 \\
1.5 \\
1.4 \\
.3 \\
3.9 \\
.8 \\
1.7\end{array}$ \\
\hline
\end{tabular}

TABLE 41.-Distribution of gold in some samples of the Challis Volcanics, central Idaho [Samples supplied by B. F. Leonard, U.S. Geol. Survey]

\begin{tabular}{|c|c|c|}
\hline Sample No. & Rock type & $A u(p p b)$ \\
\hline 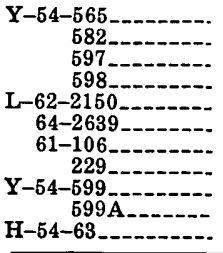 & $\begin{array}{l}\text { Andesite } \\
\text { Andesite tuff } \\
\text { Dacite } \\
\text { Latite } \\
\text { Latite tuff } \\
\text { Rhyolite } \\
\text { Rhyolite tuff }\end{array}$ & $\begin{array}{r}0.3 \\
1.0 \\
.4 \\
.5 \\
.9 \\
1.0 \\
.6 \\
.3 \\
1.0 \\
1.7 \\
.4\end{array}$ \\
\hline
\end{tabular}

TABLE 42.-Distribution of gold in some calc-alkalic metavolcanic rocks from the southern Appalachians, North Carolina and Virginia [Samples supplied by D. W. Rankin and A. A. Stromquiist,

\begin{tabular}{|c|c|c|}
\hline Sample No. & Rock type & $\mathrm{Au}(\mathrm{ppb})$ \\
\hline \multicolumn{3}{|c|}{ Denton quadrangle, North Carolina } \\
\hline 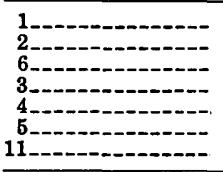 & $\begin{array}{l}\text { Andesitic tuff breccia } \\
\text { Rhyolitic flow } \\
\text { Rhyolitic tuff } \\
\text { Rhyolitic vitrophyre }\end{array}$ & $\begin{array}{r}1.9 \\
.5 \\
.8 \\
.5 \\
.6 \\
.4 \\
.9\end{array}$ \\
\hline \multicolumn{3}{|c|}{ Mount Rogers Formation, Virginia } \\
\hline 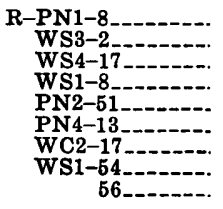 & $\begin{array}{l}\text { Porphyritic rhyolite } \\
\text { Porphyritic rhyolite dike } \\
\text { Phenocryst-poor rhyolite } \\
\text { Podo do }\end{array}$ & $\begin{array}{r}0.1 \\
2.8 \\
.3 \\
.4 \\
.1 \\
.2 \\
.3 \\
.5 \\
.2\end{array}$ \\
\hline
\end{tabular}

TABLE 43.-Distribution of gold in alkalic igneous rocks from Big Bend National Park, Tex.

[Samples supplied by J. T. Lonsdale, Univ. of Texas]

\begin{tabular}{|c|c|c|}
\hline Sample No. & Rock type & $\mathrm{Au}(\mathrm{ppb})$ \\
\hline 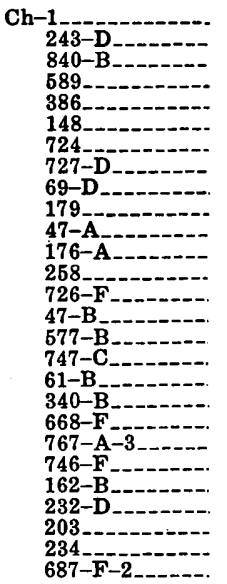 & $\begin{array}{l}\text { Porphyritic olivine basalt } \\
\text { Nepheline basalt, intrusive } \\
\text { Basalt, intrusive } \\
\text { Porphyritic olivine basalt, extrusive } \\
\text { Olivine basalt, intrusive } \\
\text { Porphyritic olivine basalt, intrusive } \\
\text { Basalt porphyry, extrusive } \\
\text { Analcite labradorite syenite } \\
\text { Analcite syenogabbro } \\
\text { Syenogabbro, intrusive } \\
\text { Analcite andesine syenite, intrusive } \\
\text { Olivine syenodiorite, intrusive } \\
\text { Trachyandesite, extrusive } \\
\text { Analcite syenite, intrusive } \\
\text { Trachyandesite porphyry, extrusive } \\
\text { Augite soda trachyte, intrusive } \\
\text { Aegerine augite trachyte, intrusive } \\
\text { Riebeckite trachyte, extrusive } \\
\text { Pyroxene microgranite, intrusive } \\
\text { Riebeckite rhyolite, extrusive } \\
\text { Riebeckite granite, intrusive } \\
\text { Riebeckite granophyre, intrusive } \\
\text { Riebeckite microgranite porphyry } \\
\text { Riebeckite granophyre, intrusive, } \\
\text { Quartz sanidine porphyry, intrusive }\end{array}$ & $\begin{array}{r}0.5 \\
.9 \\
.5 \\
.8 \\
4.3 \\
.6 \\
.3 \\
.5 \\
.4 \\
.5 \\
.4 \\
1.0 \\
1.0 \\
.4 \\
.2 \\
.4 \\
.6 \\
.2 \\
.4 \\
1.9 \\
.3 \\
.4 \\
.4 \\
.2 \\
.8 \\
1.2 \\
.4\end{array}$ \\
\hline
\end{tabular}

TABLE 44.-Distribution of gold in subsilicic alkalic rocks from central Montana

[Samples supplied by W. T. Pecora and E. S. Larsen, Jr., U.S. Geol. Survey]

\begin{tabular}{|c|c|c|}
\hline Sample No. & Rock type & $A u(p p b)$ \\
\hline \multicolumn{3}{|c|}{ Boxelder laccolith, Bearpaw Mountains } \\
\hline 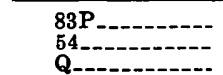 & $\begin{array}{l}\text { Pegmatitic patch in syenite } \\
\text { Aplite dike in syenite } \\
\text { Syenite (summit), } 360 \mathrm{ft} \text { above base }\end{array}$ & $\begin{array}{r}1.4 \\
1.4 \\
.4\end{array}$ \\
\hline
\end{tabular}


TABLE 44.-Distribution of gold in subsilicic alkalic rocks from central Montana-Continued

\begin{tabular}{|c|c|c|}
\hline Sample No. & Rock type & $\mathrm{Au}(\mathrm{ppb})$ \\
\hline \multicolumn{3}{|c|}{ Boxelder laccolith, Bearpaw Mountains - Continued } \\
\hline 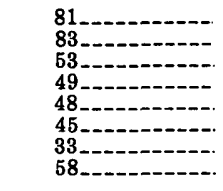 & $\begin{array}{l}\text { Syenite, } 335 \mathrm{ft} \text { above base } \\
\text { Syenite, } 300 \mathrm{ft} \text { above base } \\
\text { Mafic syenite, } 210 \mathrm{ft} \text { above base } \\
\text { Friable shonkinite, } 90 \mathrm{ft} \text { above base } \\
\text { Basal shonkinite, } 70 \mathrm{ft} \text { above base } \\
\text { Basal shonkinite, } 25 \mathrm{ft} \text { above base } \\
\text { Hard shonkinite, basal zone } \\
\text {--do do- }\end{array}$ & $\begin{array}{l}2.9 \\
1.1 \\
2.7 \\
6.1 \\
3.6 \\
4.0 \\
2.4 \\
4.1\end{array}$ \\
\hline \multicolumn{3}{|c|}{ Shonkin Sag laccolith, Highwood Mountains } \\
\hline
\end{tabular}

TABLE 44.-Distribution of gold in subsilicic alkalic rocks from central Montana-Continued

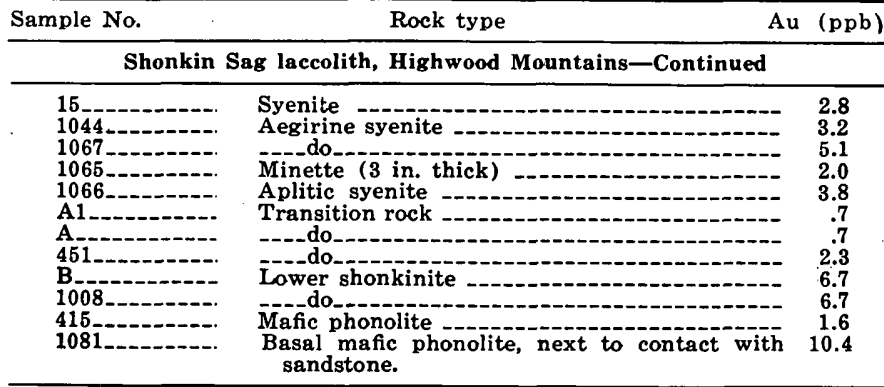

U. S. GOVERNMENT PRINTING OFFICE : 1972 O - 443-785 